\title{
Intensive Cultural Resources Survey of the Proposed Wurzbach Parkway Extension Project from Blanco Road to Wetmore Road, Bexar County, Texas
}

Mary Jo Galindo

Galindo Environmental Consulting LLC

Kevin A. Miller

SWCA

Follow this and additional works at: https://scholarworks.sfasu.edu/ita

Part of the American Material Culture Commons, Archaeological Anthropology Commons, Environmental Studies Commons, Other American Studies Commons, Other Arts and Humanities Commons, Other History of Art, Architecture, and Archaeology Commons, and the United States History Commons

Tell us how this article helped you.

This Article is brought to you for free and open access by the Center for Regional Heritage Research at SFA ScholarWorks. It has been accepted for inclusion in Index of Texas Archaeology: Open Access Gray Literature from the Lone Star State by an authorized editor of SFA ScholarWorks. For more information, please contact cdsscholarworks@sfasu.edu. 


\section{Intensive Cultural Resources Survey of the Proposed Wurzbach Parkway Extension Project from Blanco Road to Wetmore Road, Bexar County, Texas}

\section{Licensing Statement}

This is a work for hire produced for the Texas Department of Transportation (TxDOT), which owns all rights, title, and interest in and to all data and other information developed for this project under its contract with the report producer. The report may be cited and brief passages from this publication may be reproduced without permission provided that credit is given to TxDOT and the firm that produced it. Permission to reprint an entire chapter, section, figures or tables must be obtained in advance from the Supervisor of the Archeological Studies Branch, Environmental Affairs Division, Texas Department of Transportation, 125 East 11th Street, Austin, Texas, 78701. 
INTENSIVE CULTURAL RESOURCES SURVEY

OF THE PROPOSED WURZBACH PARKWAY EXTENSION PROJECT

FROM BLANCO ROAD TO WETMORE ROAD, BEXAR COUNTY, TEXAS

(CSJs 0915-12-137, 0915-12-224, 8000-12-012, 8000-15-008, 8000-15-011, 8000-15-012, and 8000-15-015)

\author{
Prepared for \\ TEXAS DEPARTMENT OF TRANSPORTATION \\ 123 East $11^{\text {th }}$ Street \\ Austin, Texas 78701 \\ Prepared by \\ Mary Jo Galindo and Kevin A. Miller \\ with contributions by Al McGraw
}

\title{
SWCA ENVIRONMENTAL CONSULTANTS
}

4407 Monterey Oaks Blvd.

Building 1, Suite 110

Austin, Texas 78749

www.swca.com

Principal Investigator

Mary Jo Galindo

Texas Antiquities Permit 4494

SWCA Project Number 12612-053-AUS

SWCA Cultural Resource Report No. 07-225

TxDOT Archaeological Studies Program, Report No. 125

December 31, 2010 


\title{
INTENSIVE CULTURAL RESOURCES SURVEY \\ OF THE PROPOSED WURZBACH PARKWAY EXTENSION PROJECT FROM BLANCO ROAD TO WETMORE ROAD, BEXAR COUNTY, TEXAS
}

\author{
(CSJs 0915-12-137, 0915-12-224, 8000-12-012, 8000-15-008, 8000-15-011, \\ 8000-15-012, and 8000-15-015)
}

Copyright (C) 2010

Texas Department of Transportation (TxDOT) and SWCA, Incorporated (SWCA)

TxDOT and SWCA jointly own all rights, title, and interest in and to all data and other information developed for this project under Work Authorization 57803SA005. Brief passages from this publication may be reproduced without permission provided that credit is given to TxDOT and SWCA. Permission to reprint an entire chapter, section, figures, or tables must be obtained in advance from the Supervisor of the Archeological Studies Program, Environmental Affairs Division, Texas Department of Transportation, 125 East $11^{\text {th }}$ Street, Austin, Texas 78701. Copies of this publication have been deposited with the Texas State Library in compliance with the State Depository requirements.

Printed by Ginny's Printing, Austin, Texas

Jointly published by the

Texas Department of Transportation

Environmental Affairs Division

Archaeological Studies Program

Scott Pletka, Ph.D., Supervisor

Archaeological Studies Program, Report No. 125

A. McGraw, Series Editor

and

SWCA, Incorporated

Austin, Texas

SWCA Cultural Resources Report No. 07-225

Texas Antiquities Permit 4494

ISBN: 1-930788-94-0 


\begin{abstract}
SWCA Environmental Consultants (SWCA) conducted an intensive cultural resources survey on behalf of the Texas Department of Transportation (TxDOT), of the proposed Wurzbach Parkway Extension Project in San Antonio, Texas. TxDOT proposes to extend the existing Wurzbach Parkway approximately 5.3 miles between Farm-to-Market Road (FM) 2696 (Blanco Road) and Wetmore Road. The undertaking involves the new construction of a four-lane divided roadway within an approximately 250 -foot right-of-way (ROW) that is state-owned property. Overall, the Area of Potential Effects (APE) is 27,984 feet long, 250 feet wide, and maximally 10 feet deep. Additionally, the APE covers roughly 51.77 acres of permanent and temporary easements. SWCA's investigations of the Wurzbach Parkway Extension Project APE included a background review, and an intensive pedestrian survey with shovel testing and backhoe trenching of selected areas within the APE.

The background literature review determined that 21 surveys of varying magnitude have been conducted within or adjacent to the APE. These surveys are related to roadway construction or expansion, as well as park development. Fourteen archaeological sites have been documented within or adjacent to the APE and 44 additional archaeological sites have been previously recorded within 1 mile of it. The APE traverses a portion of the Walker Ranch National Register District, but the undertaking does not affect any contributing resources besides those that were previously mitigated by TxDOT in the 1990s.

SWCA archaeologists conducted field investigations within the Wurzbach Parkway Extension Project APE between May 1 and June 21, 2007. The pedestrian survey established that the majority of the APE has been disturbed by previous residential, commercial, and dam construction. Of the 14 previously recorded sites within or immediately adjacent to the APE, seven were determined during the current survey not to extend into the APE (41BX181, 41BX183, 41BX194, 41BX203, 41BX209, 41BX222, and 41BX223). Two of the seven sites within the APE had been successfully mitigated through prior data recovery efforts (41BX184 and 41BX228), while landforms associated with site 41BX202 were found to have been completely destroyed. Current investigations included a reconnaissance survey of site 41BX949, shovel testing at site 41BX948, and backhoe trenching at site 41BX947. Right of entry was denied at two properties, including the Coker United Methodist Church, which precluded a revisit to $41 \mathrm{BX} 1062$.
\end{abstract}

The portions of sites 41BX184, 4BX202, 41BX228, and 41BX949 that remain in the Wurzbach Parkway Extension Project APE are not considered eligible for inclusion to the National Register of Historic Places (NRHP) or for designation as a State Archeological Landmark (SAL); therefore, SWCA recommends no further work at these sites. Survey-level excavations at 41BX947 and 41BX948 revealed no cultural materials, temporally diagnostic artifacts, features, or intact buried deposits. Thus, 41BX947 and 41BX948 have little to no research value. As such, neither 41BX947 nor 41BX948 is considered significant or eligible for inclusion in the NRHP or for designation as an SAL. Based on the extent of previous investigations and the results of the current survey, SWCA recommends no additional archaeological investigations for 41BX184, 4BX202, 41BX228, 41BX947, 41BX948, 41BX949, and 41BX1062.

Subsequent to the SWCA survey, TxDOT conducted an impact evaluation of the additional 51.77 acres of easements associated with the project. No cultural resources were documented as part of this effort. This TxDOT work was submitted with the SWCA draft report to the Texas Historical Commission (THC) who concurred with the findings in both reports. This report combines the results of both investigations into a final report to satisfy the Texas Antiquities Code (TAC) permit requirements.

In accordance with Section 106, 36 Code of Federal Regulations (CFR) 800.4, SWCA and TxDOT have made a reasonable and good faith effort to identify archaeological historic properties within the APE. As no properties were identified that meet the criteria for listing on the NRHP according to 36 CFR 60.4 or for designation as an SAL according to 13 TAC 26.12, no archeological historic properties are affected and SWCA recommends no further work for the 5.3-mile Wurzbach Parkway Extension Project APE. Artifacts were collected as part of the undertaking and will be curated at the Texas Archeological Research Laboratory. 


\section{ACKNOWLEDGEMENTS}

Mary Jo Galindo served as Principal Investigator, Project Manager, and Lead Surveyor for the duration of the project, ably overseeing overall logistics and organization, and managing reporting and agency consultation. Michael R. Chavez, Ken Lawrence, Kevin A. Miller, Christina Nielsen, David Wilcox, and Ernest Wingate served as field technicians on this survey, conducting field work between May 1 and June 21, 2007. TxDOT archaeologist Al McGraw conducted additional fieldwork on October 2-3, 2009. Carole Carpenter expertly produced all field and report maps for the project. 


\section{TABLE OF CONTENTS}

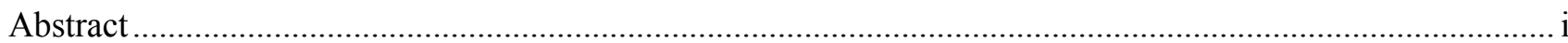

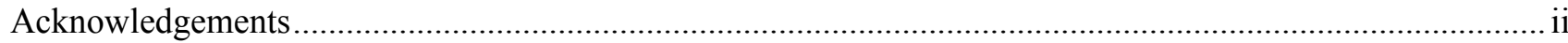

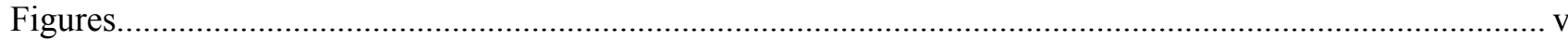

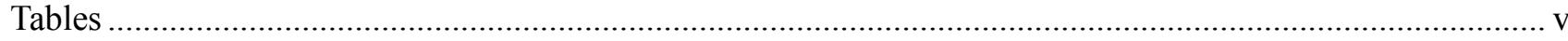

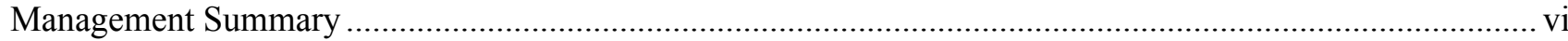

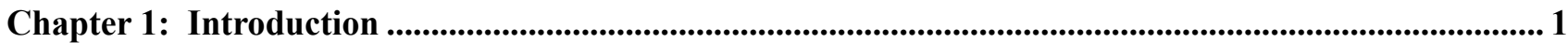

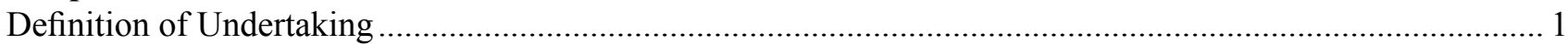

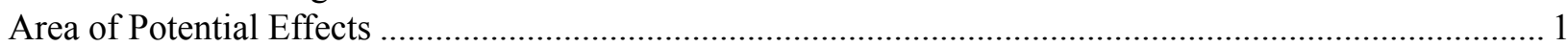

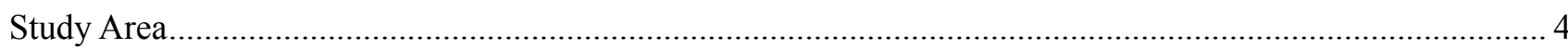

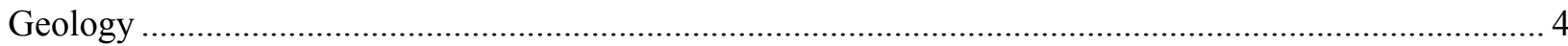

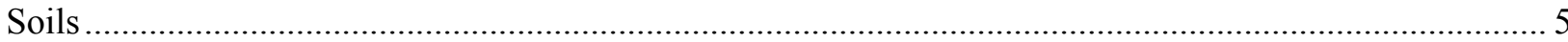

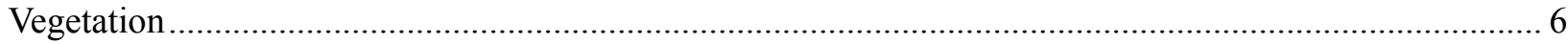

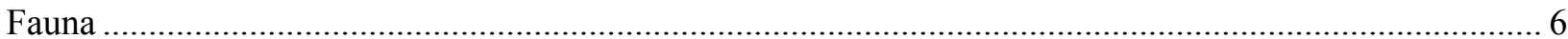

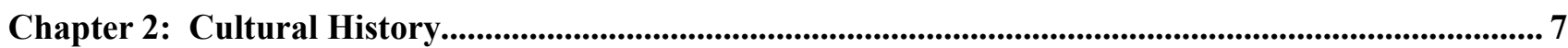

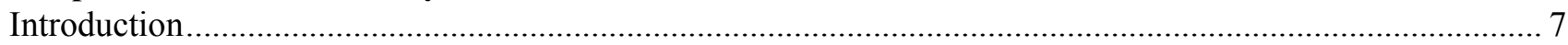

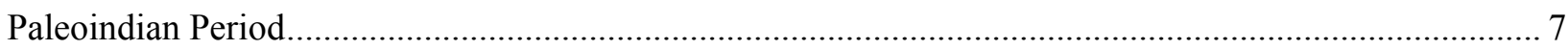

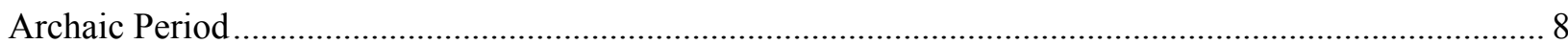

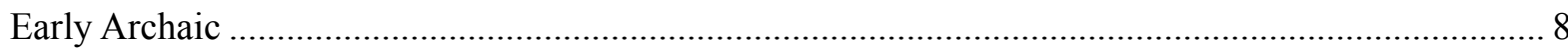

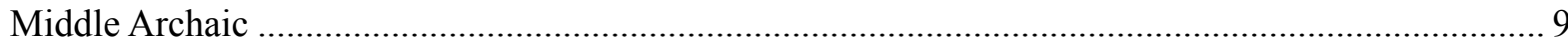

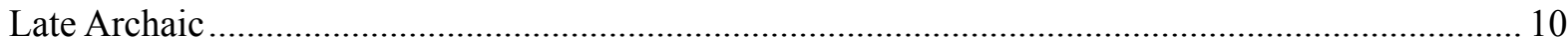

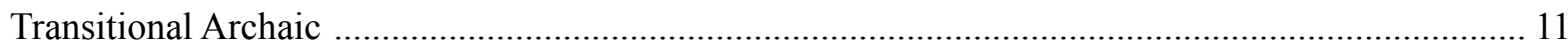

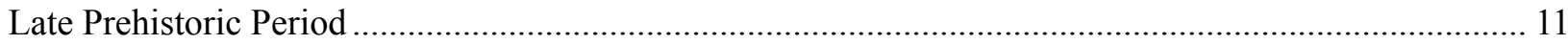

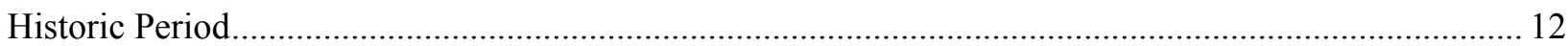

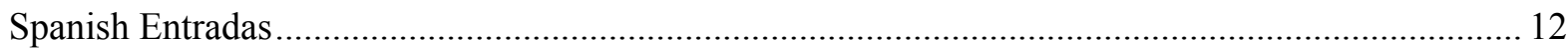

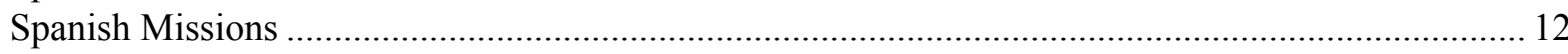

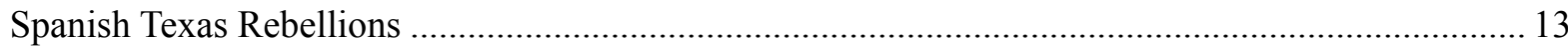

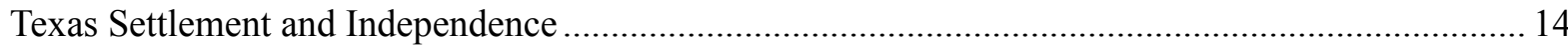

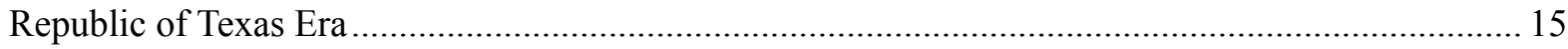

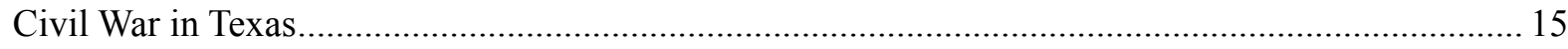

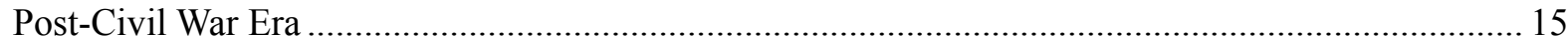

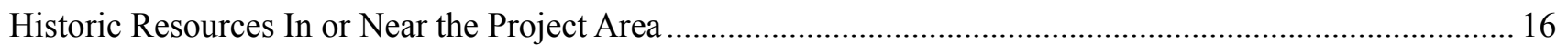

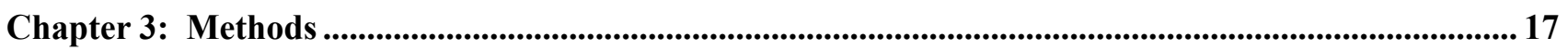

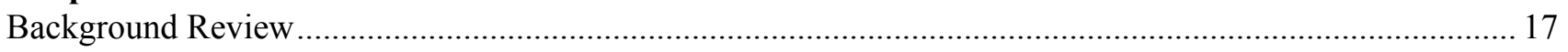

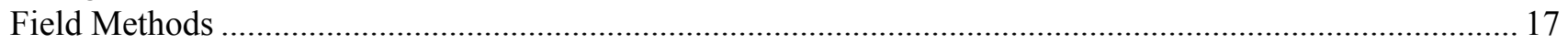

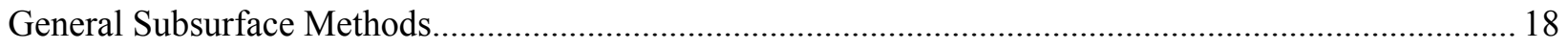

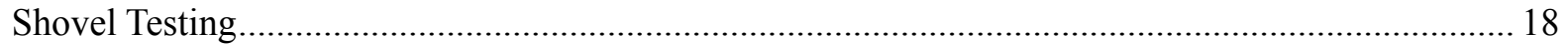

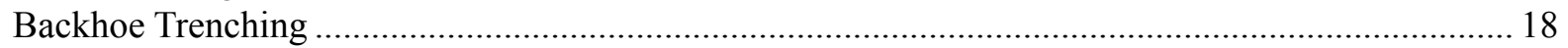

Chapter 4: Previous Investigations and Recorded Archaeological Sites ............................................... 19

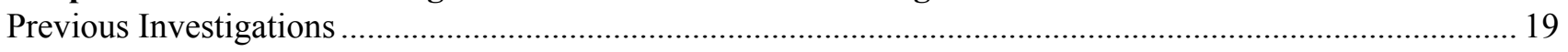

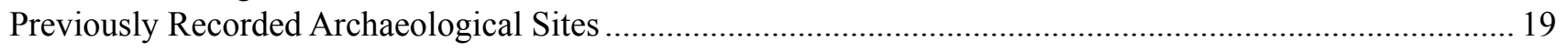

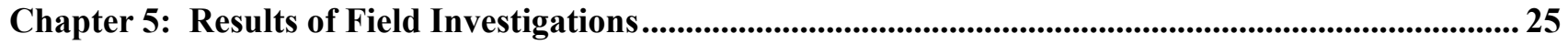

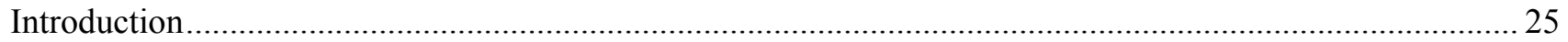

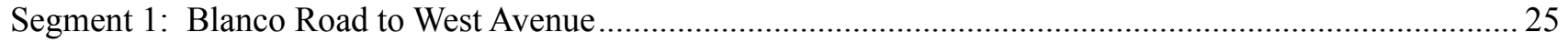

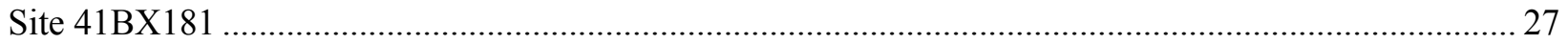

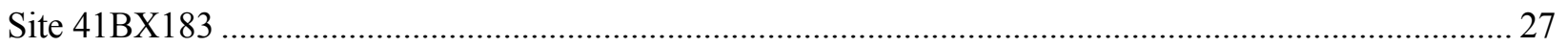

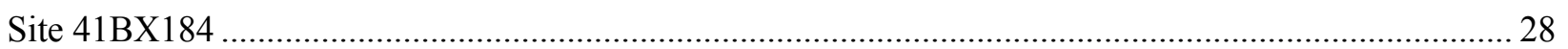

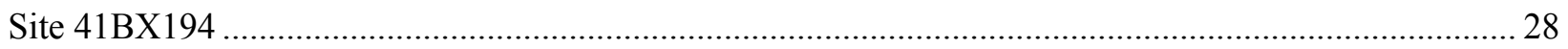




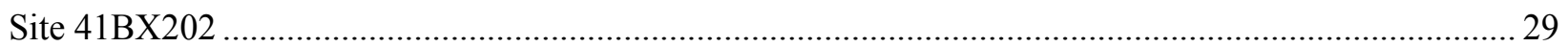

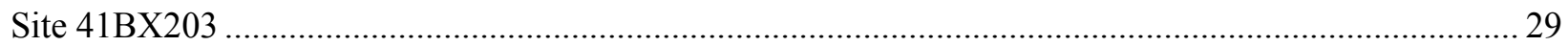

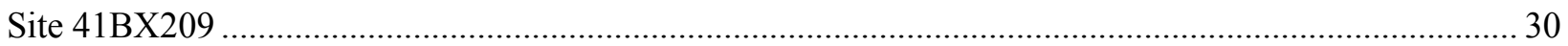

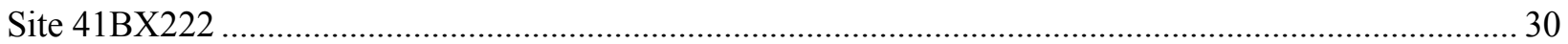

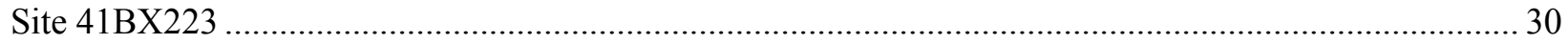

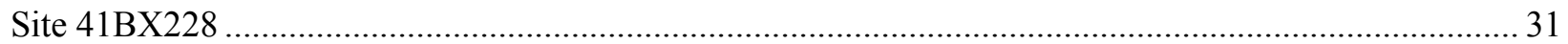

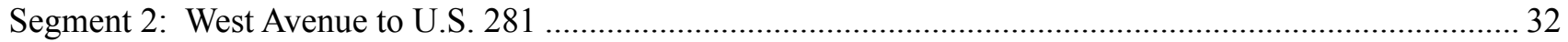

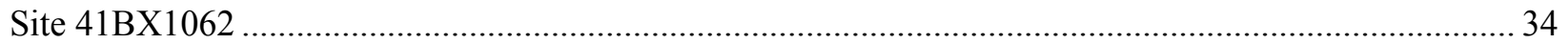

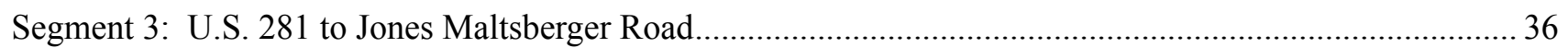

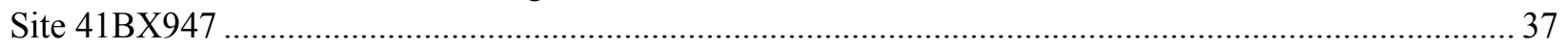

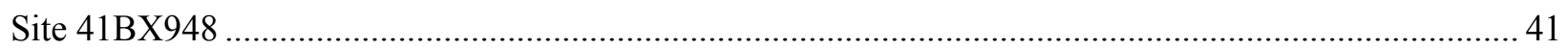

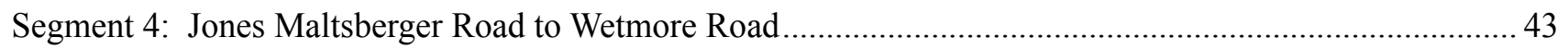

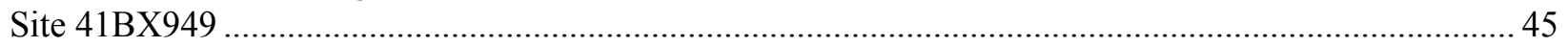

Chapter 6: Summary and Recommendations ...................................................................................................4 47

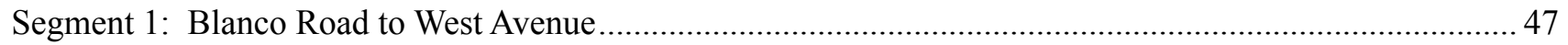

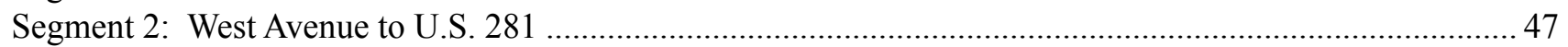

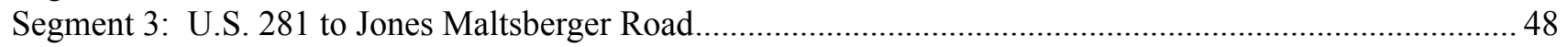

Segment 4: Jones Maltsberger Road to Wetmore Road ............................................................................ 48

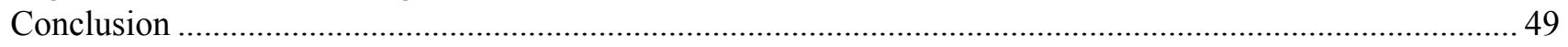

References ..................................................................................................................................................................................5 51

\section{Appendix A: Interim Report}




\section{Figures}

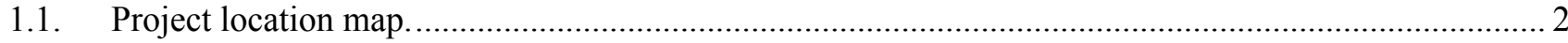

1.2. Typical section for the proposed Wurzbach Parkway Extension project from Blanco Road to West Vista del Norte and from West Avenue to U.S. 281 .......................................................................... 3

1.3. Typical section for the proposed Wurzbach Parkway Extension project from West Vista del Norte to West Avenue and from U.S. 281 to Wetmore Road. ......................................................................... 4

4.1. Archaeological sites within or adjacent to the Wurzbach Parkway extension project......................... 23

5.1. Segment 1, Wurzbach Parkway from Blanco Road to West Avenue. ................................................. 26

5.2. Proposed Wurzbach Parkway right-of-way at Vista del Norte and Blanco Road facing west.............. 26

5.3. Proposed Wurzbach Parkway right-of-way between Blanco Road and Vista del Norte near site

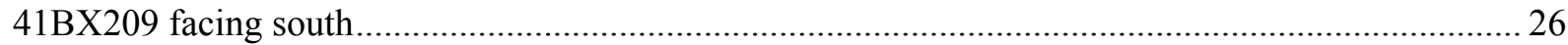

5.4. Proposed Wurzbach Parkway right-of-way east of Vista del Norte near sites 41BX181 and 41BX183

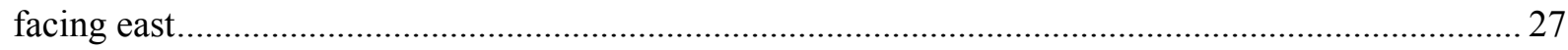

5.5. Proposed Wurzbach Parkway right-of-way west of Vista del Norte near site 41BX184 facing west ... 27

5.6. Proposed Wurzbach Parkway right-of-way at site 41BX184 taken from the top of the flood control dam, facing east................................................................................................................... 28

5.7. Fragments of two Pedernales projectile points recovered from the surface of site 41BX228............. 32

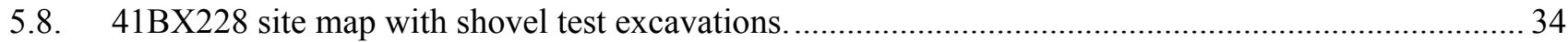

5.9. Segment 2, Wurzbach Parkway from West Avenue to U.S. 281 ................................................... 35

5.10. Proposed Wurzbach Parkway right-of-way on the west side of U.S. 281 and Salado Creek ............... 35

5.11. Cutbank along Salado Creek on the west side of U.S. 281, facing south. ..................................... 35

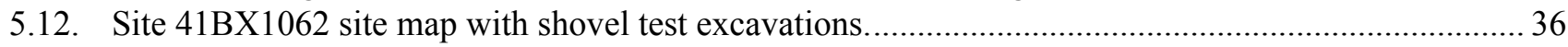

5.13. Segment 3, Wurzbach Parkway from U.S. 281 to Jones Maltsberger Road. ....................................... 37

5.14. Concrete fragments, tile, and other building materials were encountered at $1 \mathrm{~m}$ deep in BHT $18 \ldots . . . .41$

5.15. Construction debris in the right-of-way at Station No. 221, facing north ....................................... 41

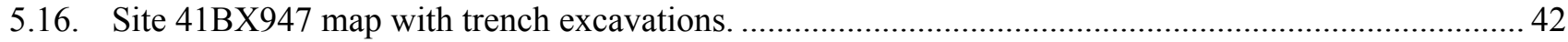

5.17. Proposed Wurzbach Parkway right-of-way at site 41BX947 near U.S. 281 and Salado Creek ........... 42

5.18. Proposed Wurzbach Parkway right-of-way at site 41BX947 near U.S. 281 and Salado Creek ............ 43

5.19. Proposed Wurzbach Parkway right-of-way at site 41BX947, facing west ................................... 43

5.20. Proposed Wurzbach Parkway right-of-way near site 41BX947, facing south................................. 43

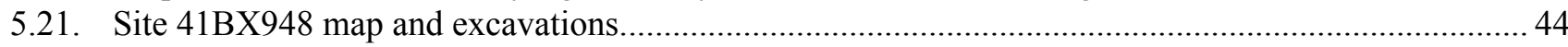

5.22. Proposed Wurzbach Parkway right-of-way near site 41BX948, facing west ................................... 44

5.23. Proposed Wurzbach Parkway right-of-way near site 41BX948, facing east ................................... 44

5.24. Segment 4, Wurzbach Parkway from Jones Maltsberger to Wetmore Road....................................... 45

\section{Tables}

1.1. Project Area Soil Descriptions, West to East...............................................................................

4.1. Previous Archaeological Surveys of the Wurzbach Parkway Between Blanco to Wetmore Roads ...... 20

4.2. Previously Recorded Archaeological Sites Within or Immediately Adjacent to the Wurzbach Parkway APE Between Blanco and Wetmore Roads ...................................................................... 22

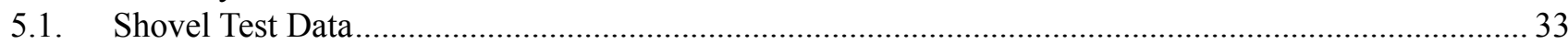

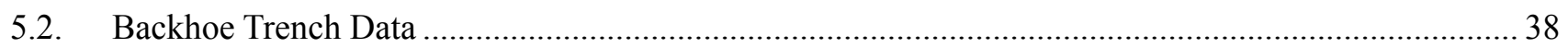




\section{Management Summary}

Project TitLe: Intensive Cultural Resources Survey of the Proposed Wurzbach Parkway Extension Project from Blanco Road to Wetmore Road, Bexar County, Texas.

SWCA Project Number: 12612-053-AUS.

TxDOT CSJ Numbers: 0915-12-137, 0915-12-224, 8000-12-012, 8000-15-008, 8000-15-011, 8000-15-012, and 8000-15-015.

Project Description: TxDOT proposes new roadway construction for the approximately 160.6-acre Wurzbach Parkway Extension APE between Blanco Road and Wetmore Road. The APE is 27,984 feet long and 250 feet wide, and maximally 10 feet deep. Additionally, the APE covers 51.77 acres of permanent and temporary easements. The proposed project would involve various surface and subsurface impacts related to the construction of the roadway and drainage ditches, the installation of utilities, and landscaping. The archaeological work consisted of a background records review, pedestrian survey, shovel testing, and backhoe trenching of selected areas within the APE.

Location: The APE is located in northern Bexar County along Salado Creek in San Antonio, Texas. It parallels and crosses the floodplain in addition to traversing adjacent upland areas for a distance of approximately 5.3 miles between Blanco and Wetmore roads. The APE appears on the Castle Hills and Longhorn U.S. Geological Survey 7.5-minute quadrangles.

Number of ACres Surveyed: Approximately 160.61 acres plus 51.77 acres of easements.

Principal Investigator: Mary Jo Galindo.

DATES OF Work: The SWCA survey was performed from May 1 through June 21, 2007 and TxDOT conducted a survey associated with the project on October 2-3, 2009.

Purpose of Work: Since the proposed undertaking will involve federal funds from the Federal Highway Administration (FHWA) and involves state land controlled by TxDOT's San Antonio District, investigations were conducted in compliance with the TAC; the National Historic Preservation Act; and the First Amended Programmatic Agreement among the FHWA, TxDOT, the Texas State Historic Preservation Officer, and the Advisory Council on Historic Preservation regarding the implementation of transportation undertakings.

NuMBer of Sites: Fourteen adjacent and within (41BX181, 41BX183, 41BX184, 41BX194, 41BX202, 41BX203, 41BX209, 41BX222, 41BX223, 41BX228, 41BX947, 41BX948, 41BX949, and 41BX1062).

Eligibility of Sites: None of the seven sites within the APE (41BX184, 41BX202, 41BX228, 41BX947, 41BX948, 41BX949, and 41BX1062) is eligible for inclusion in the NRHP or for designation as an SAL.

Comments: No further work is recommended. Artifacts were collected as part of the undertaking and will be curated at the Texas Archeological Research Laboratory. 


\section{Chapter 1}

\section{INTRODUCTION}

On behalf of HNTB Corporation and the Alamo Regional Mobility Authority (RMA), SWCA Environmental Consultants (SWCA) conducted a cultural resources investigation under Antiquities Permit 4494 of the roughly 5.3-mile Wurzbach Parkway Extension Project located in northern San Antonio, Texas (Figure 1.1). Subsequent to the survey, the project and the permit were transferred to the Texas Department of Transportation (TxDOT), Environmental Affairs Division, under whose oversight the report was completed.

Investigations were performed as part of TxDOT's compliance with requirements of the Texas Antiquities Code (TAC) under the aforementioned antiquities permit issued by the Texas Historical Commission (THC); Section 106 of the National Historic Preservation Act (NHPA) of 1966, as amended; the Programmatic Agreement between the Federal Highway Administration (FHWA), the Advisory Council on Historic Preservation, TxDOT, and the Texas State Historic Preservation Officer; and the Memorandum of Understanding between TxDOT and the THC.

The investigations consisted of an extensive archaeological background literature and maps review and intensive pedestrian survey with shovel testing and backhoe trenching of selected areas within the project area. The purposes of the investigation were to determine if the undertaking would adversely affect significant archaeological historic properties. Mary Jo Galindo served as Principal Investigator, and SWCA archaeologists conducted the field survey between May 1 and June 21, 2007.

Subsequent to the SWCA survey, TxDOT archaeologist Al McGraw conducted a survey of an additional 51.77 acres of permanent and temporary easements included as part of a minor design change to the Wurzbach Parkway Extension Project. The results and locations of this subsequent survey are incorporated into the maps in this report and the full results are presented in their entirety in Appendix A.

\section{DEFinition OF UNDERTAKING}

The 5.3-mile-long Wurzbach Parkway Extension Project parallels and crosses the floodplain of Salado Creek and adjacent upland areas from its western boundary at Farm-to-Market Road (FM) 2696 (Blanco Road) to its eastern boundary at Wetmore Road in northern San Antonio. This 5.3-mile roadway extension will link up the existing built sections of Wurzbach Parkway on the west and east. The existing section of Wurzbach Parkway to the west of the current survey area is between Lockhill-Selma Road and FM 2696. The existing section of Wurzbach Parkway to the east of the current survey area is between Starcrest Drive and O'Connor Road, with a connection to Interstate Highway (IH) 35 through O'Connor Road.

\section{Area of Potential Effects}

Overall, the Area of Potential Effects (APE) is 27,984 feet long, and 250 feet wide. The vertical depth of impacts has not been specified in detail. However, construction within a typical roadway will not impact deposits greater than 4 feet. Impacts at creek crossings may also entail cutting the banks to a depth of at least 10 feet for a distance of at least 25 feet from the existing edge of the banks.

The APE also includes 51.77 acres of permanent and temporary easements. The majority of the easements are linear, parallel to the highway, and often $40-50$ feet wide. The average depth of impacts within easements are within 3 feet of existing ground surface but the maximum depth of construction impacts at easement Locale 4 is estimated at 20 feet to accommodate a storm water outfall. Thus, the APE is mainly 27,984 feet long and 250 feet wide with 51.77 acres of easements and vertical impacts of 3 feet throughout, 10 feet at creek crossings, and up to 20 feet at Locale 4, for a total area of 212.38 acres.

Preliminary roadway construction plans call for a 250-foot-wide right-of-way (ROW) from Blanco Road to West Vista del Norte and from West Avenue to U.S. Highway (U.S.) 281 (Figure 1.2). The 250-foot-wide 


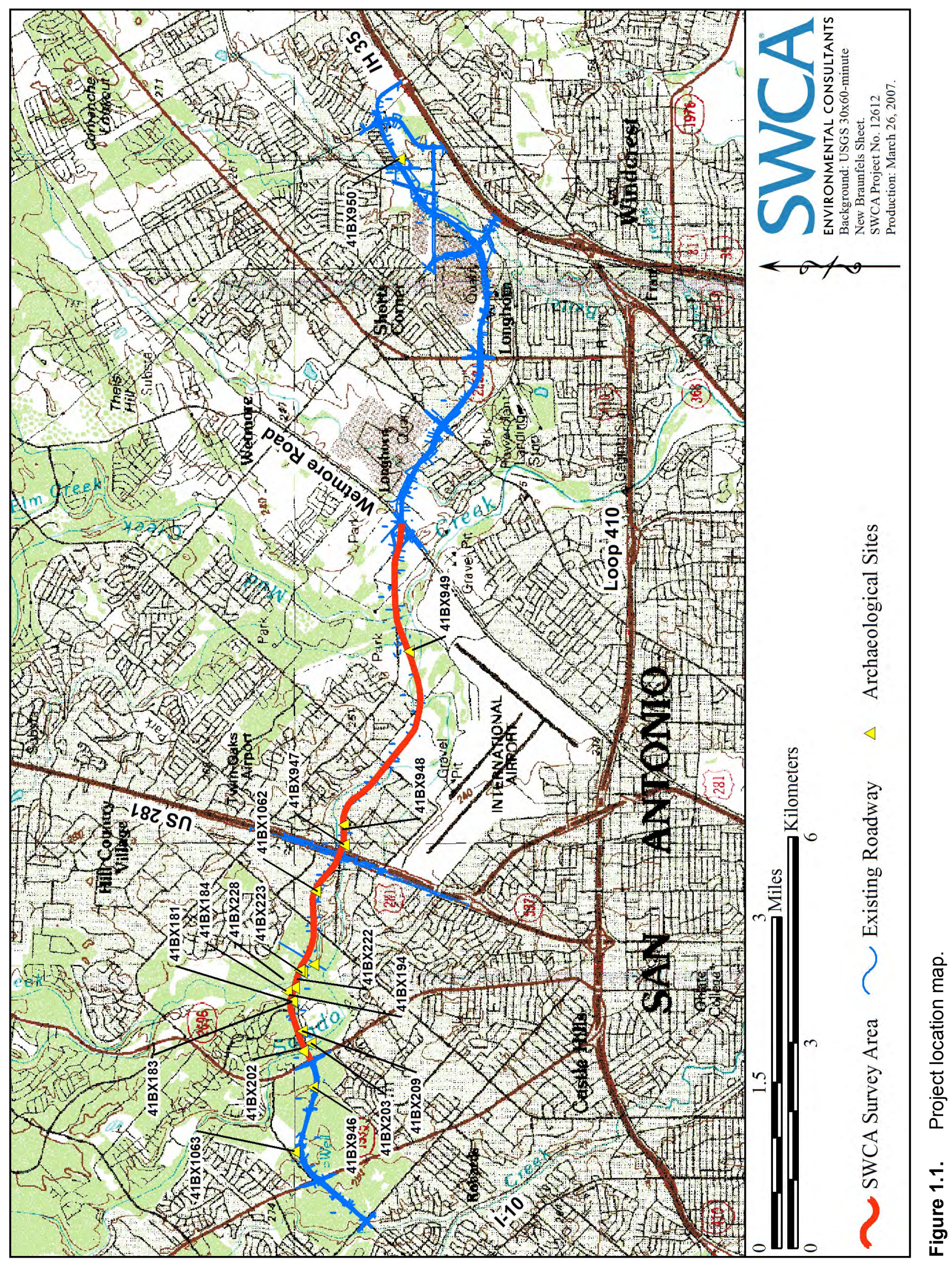




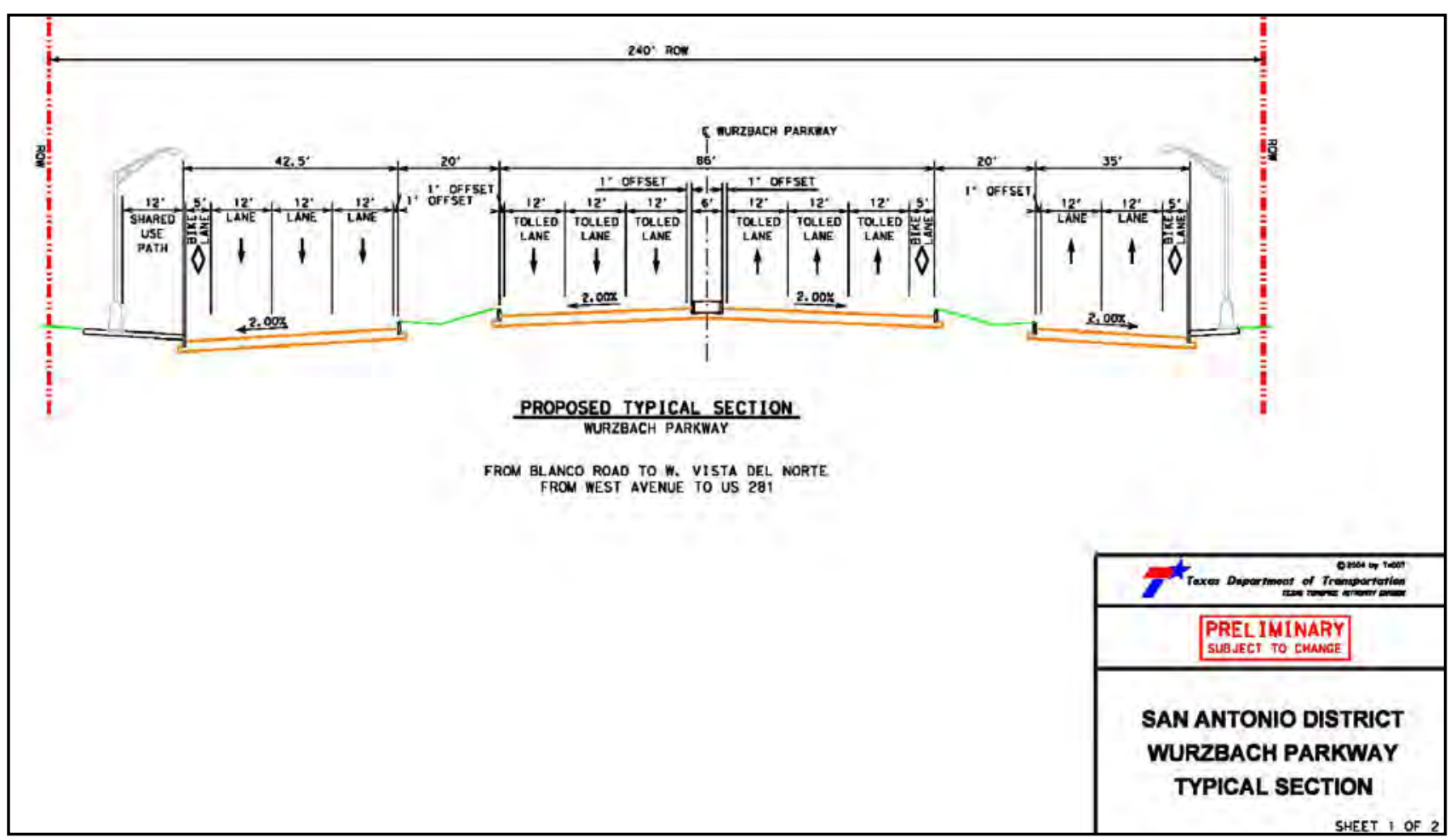

Figure 1.2. Typical section for the proposed Wurzbach Parkway Extension project from Blanco Road to West Vista del Norte and from West Avenue to U.S. 281.

ROW will consist of two sets of three centrally-located, 12-foot-wide tolled lanes separated by a 6 -foot median. A 5-foot-wide bike lane would be adjacent to one set of these tolled lanes. The central lanes would be separated by 20 -foot medians from two sets of frontage lanes on either side. One set of frontage lanes would be comprised of two 12-foot frontage lanes and a 5-foot bike lane; the other set would have three 12-foot frontage lanes, a 5-foot bike lane, and a 12-foot shared use path. As mentioned, 51.77 acres of permanent and temporary easements were later added to the overall APE and investigated by TxDOT.

From West Vista del Norte to West Avenue and from U.S. 281 to Wetmore Road, the ROW will vary from 120-187 feet in width (Figure 1.3). These portions of the Wurzbach Parkway Extension Project would consist of two sets of three 12-foot wide tolled lanes separated by a 6 -foot median. A 5-foot-wide bike lane would be adjacent to one set of lanes. Outside of the ROW, a 10-foot-wide shared use path would be constructed within a temporary construction easement.

The Wurzbach Parkway Extension Project includes road segments that were previously designated by TxDOT with CSJ numbers as follows:
- 0915-12-224 the APE between Blanco Road and West Avenue;

- 8000-15-008 West Avenue to U.S. 281;

- 8000-15-011 U.S. 281 to Jones Maltsberger; and

- 8000-15-012 from Jones Maltsberger to Wetmore Road.

All work will occur within the proposed ROW, within a 0.053-acre permanent easement between West Vista del Norte and West Avenue (see Figures 1.2 and 1.3), and within 51.717 acres of permanent and temporary easements between U.S. 281 and Wetmore Road (Appendix A).

Bridges or culverts are proposed (from west to east) at a Salado Creek crossing at Blanco Road; the outfall of the flood control dam at Panther Springs; an unnamed tributary of Salado Creek near Coker Church; Salado Creek and U.S. 281; an unnamed tributary of Salado Creek near U.S. 281; Salado Creek and Jones Maltsberger Road; Salado Creek and Bitters Road; Salado Creek east of Bitters Road; an unnamed tributary of Salado Creek east of Bitters Road; and Mud Creek. Specific designs of these bridges or culverts were not available at the time of the SWCA archaeological 


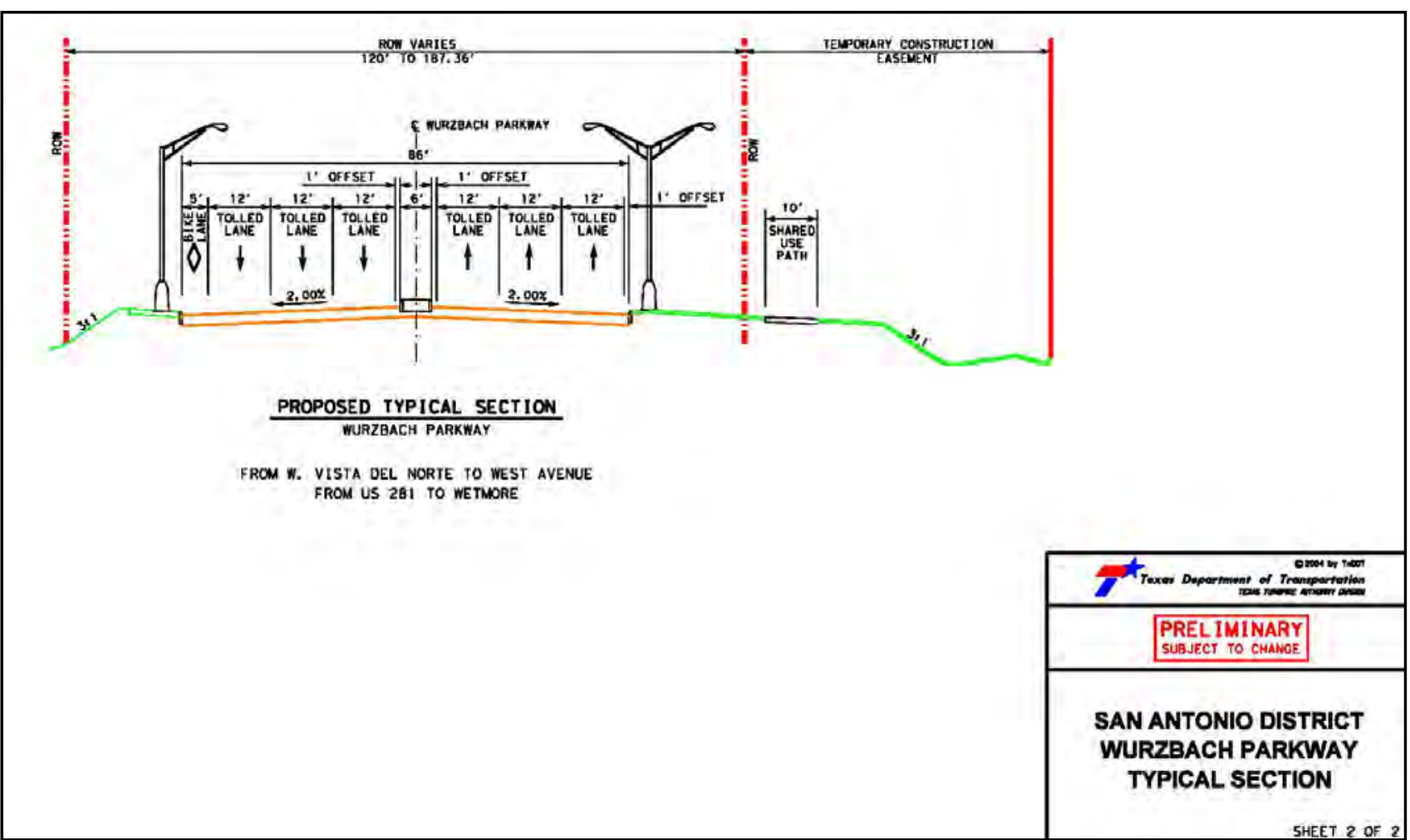

Figure 1.3. Typical section for the proposed Wurzbach Parkway Extension project from West Vista del Norte to West Avenue and from U.S. 281 to Wetmore Road.

survey, except for at the proposed Wurzbach Parkway Extension project's intersection with U.S. 281.

\section{Study Area}

The majority of the APE occupies an alluvial setting surrounded by urban development. The San Antonio area lies along the Balcones Escarpment on the southeastern margin of the Edwards Plateau. The escarpment is a fault system that divides the Hill Country to the west and north from the Blackland Prairie and coastal plains to the east and south (Abbott and Woodruff 1986). Cretaceous limestones and marls comprise the upland surface geology of the Edwards Plateau. Pleistocene and Holocene terraces border many of the area drainages (Fisher 1983).

Numerous previous disturbances occur within the APE. From Blanco Road east to an existing, massive flood control dam on Panther Springs, the APE follows West Vista del Norte for a short distance before paralleling a residential development. The APE then crosses a heavily modified area associated with the dam. To the east of West Avenue, the APE passes north of Coker Church through an area that has been modified by filling and other construction activities. Just before crossing U.S. 281, the APE bisects a residential area.
The APE on the east side of U.S. 281 is less developed and exhibits fewer prior disturbances. Sites 41BX947 and 41BX948 are located just east of the proposed intersection of U.S. 281 and the Wurzbach Parkway Extension Project. The APE follows the floodplain and terraces of Salado Creek west of Jones Maltsberger Road and this area appears relatively undisturbed, although commercial development is adjacent to the APE. For the most part, along the APE between Jones Maltsberger Road and Starcrest Road there are extensive previous disturbances from quarrying and landfill activities. Between Starcrest Road and Wetmore Road the APE follows existing roadway.

\section{GEOLOGY}

The Wurzbach Parkway Extension Project area lies within the Balcones Fault Zone, which separates the Edwards Plateau from the Gulf Coast Plain (Abbott and Woodruff 1986). The Fault Zone, or Balcones Escarpment, is a geologic fault zone several miles wide consisting of several faultings, most of which dip and are downthrown to the east. It extends in a curved line across Texas from Del Rio to the Red River. The Balcones zone was formed under conditions of strain 
during the Tertiary era, when a down warping occurred near the Gulf Coast with a moderate uplift inland (Abbott and Woodruff 1986).

Geologic outcrops in the project area consist of a Cretaceous marine limestone, mainly Austin Chalk, overlain by Quaternary fluviatile terrace deposits (Fisher 1983). The Austin Chalk is a moderately hard, grayish-white rock composed mostly of micro-granular calcite and shell fragments. The chalk is more than 350 feet thick in the project area and is underlain by the Eagle Ford Group, which is composed of shaley limestone and calcareous shale over a thin-bedded, fine-grained siltstone (Fisher 1983). Lastly, the Eagle Ford Group is underlain by the Buda Formation, a hard, fine-grained, grayish-white limestone (Fisher 1983).

\section{SoILS}

Six soil types are mapped within the APE: Trinity and Frio soils, Lewisville silty clay, Patrick soils, Tarrant soils, Pits and Quarries, and Austin silty clay (Taylor et al. 1991). An investigation of the Quaternary geology near the confluence of Panther Springs and Salado Creek in and around the project area was conducted by Charles E. Mear and Charles D. Frederick in the 1990s (Black et al. 1998a). The investigation identified three mappable alluvial deposits ranging in age from the Late Pleistocene to modern times. These deposits include an older Pleistocene deposit, a Holocene deposit, and modern floodplain deposits (identified informally as Q3, Q2, and Q1 in the published investigation) (Black et al. 1998a).
The older Pleistocene deposit (Q3) is approximately 7.0-7.5 m above the modern Panther Springs Creek bed and is predominantly mapped as Lewisville soils which consist of moderately deep, dark-colored, nearly level alluvial soils. The subsurface layer is brown silty clay about 20 inches thick. The underlying materials include reddish-yellow silty clay followed by gravel. The Lewisville soils occupy approximately 27.9 percent of the APE and occur as nearly level, broad terraces along rivers and creeks that tend to separate nearly level terraces from soils on the uplands (Table 1.1).

The Holocene deposits (Q2) are approximately $5 \mathrm{~m}$ above the modern Panther Springs Creek bed and are mapped as part of the Patrick soils series. Patrick soils are mapped in approximately 15.6 percent of the APE. These are shallow clay loams and gravelly loams found on gradual slopes along stream terraces. The surface layer is clay loam about 12 inches thick followed by more clay. The investigation determined that the "geometry and depositional fabric of the beds...suggest that the deposits occurred in a small alluvial fan or apron" (Black et al. 1998:102).

Lastly, the modern floodplain deposits (Q1) are composed of recent alluvial stream deposits mapped as Trinity and Frio soils. Thesesoils are mapped in approximately 39.1 percent of the APE in the floodplain of Salado Creek. These soils occur as narrow, long, and irregularly shaped areas. Some areas are prone to deposition, while others are prone to scouring or shifting. These soils are clay loam and gravelly clay, $1-2 \mathrm{~m}$ deep

Table 1.1. Project Area Soil Descriptions, West to East

\begin{tabular}{|l|c|l|l|}
\hline \multicolumn{1}{|c|}{ Soil Type } & $\begin{array}{c}\text { Percentage } \\
\text { of APE }\end{array}$ & \multicolumn{1}{|c|}{ Description } & \multicolumn{1}{c|}{ Location } \\
\hline $\begin{array}{l}\text { LvA - Lewisville Silty Clay } \\
\text { (0 to 1 percent slopes) and } \\
\text { LvB - Lewisville Silty Clay } \\
\text { (1 to 3 percent) }\end{array}$ & 27.9 & $\begin{array}{l}\text { Moderately deep, nearly level alluvial soils } \\
\text { on terraces and sloping areas along Salado } \\
\text { Creek }\end{array}$ & Floodplain of Salado Creek \\
\hline $\begin{array}{l}\text { Tf - Trinity and Frio soils, } \\
\text { frequently flooded }\end{array}$ & 39.1 & $\begin{array}{l}\text { Narrow, long, and irregularly-shaped areas } \\
\text { that are alternatively prone to deposition or } \\
\text { to scouring }\end{array}$ & Floodplain of Salado Creek \\
\hline $\begin{array}{l}\text { TaB - Tarrant association, gently } \\
\text { undulating and } \\
\text { TaC - Tarrant association, rolling }\end{array}$ & 8.9 & $\begin{array}{l}\text { Very shallow, stony soils on limestone } \\
\text { prairies }\end{array}$ & $\begin{array}{l}\text { Small amounts near Blanco Road and } \\
\text { at U.S. 281 }\end{array}$ \\
\hline $\begin{array}{l}\text { PaB - Patrick Clay Loam } \\
\text { (1 to 3 percent slopes) }\end{array}$ & 15.6 & $\begin{array}{l}\text { Shallow soils along terraces that drain } \\
\text { limestone prairies }\end{array}$ & $\begin{array}{l}\text { Small amounts near West Avenue, } \\
\text { U.S. 281, and between Bitters and } \\
\text { Wetmore roads }\end{array}$ \\
\hline Pt -Pits and Quarries & 6.1 & $\begin{array}{l}\text { Gravel, sand, and clay pits; limestone and } \\
\text { rock quarries; and land fills }\end{array}$ & $\begin{array}{l}\text { Areas east of West Avenue, either side } \\
\text { of Jones-Maltsberger, and at Bitters } \\
\text { Road }\end{array}$ \\
\hline $\begin{array}{l}\text { AuB - Austin silty clay } \\
\text { (1 to 3 percent slopes) }\end{array}$ & 2.2 & moderately deep, upland slopes & Small amount near Wetmore Road \\
\hline
\end{tabular}


The areas along the Salado and Panther Springs Creek valleys above their confluence were unable to be fully investigated by Mear and Frederick due to lack of exposure, land access, and time constraints. Therefore, a portion of this area in their report (Black et al. 1998a) is mapped as undifferentiated older Pleistocene deposits and Holocene deposits (Q2/Q3).

Due to numerous modern human modifications within the project area, about 6.1 percent of the APE is mapped as Pits and Quarries. The remaining 2.2 percent of the survey area is mapped as Austin silty clay soils, which are moderately deep, moderately dark colored, and very strongly calcareous clayey upland soils. They have gentle to undulating, convex slopes and developed under grass in material weathered from chalk or chalky marl. Surface layer is silty clay about 28 inches thick, followed by another silty clay layer about 18 inches thick, and then chalky marl.

\section{VEGETATION}

The APE is located within the Edwards Plateau region as defined by Gould (1975) and the Balconian biotic zone (Blair 1950). Upland areas are dominated by a mixed live oak (Quercus virginiana) and Ashe juniper (Juniperus ashei) woodland interspersed with occasional grassy openings. The lower elevation areas along the riparian zone of Salado Creek include a dense understory of acacia (Acacia sp.), prickly pear (Opuntia leptocaulis), and other brushy species (Petrides 1988; Simpson 1988). Portions of the project area have also been modified heavily, with grasses and cleared areas near residential portions and ornamental vegetation in both commercial and residential sections.

\section{FAUNA}

Common mammals of the Balconian biotic zone include white tailed deer (Odocoileus virginianus), opossum (Didelphis virginiana), raccoon (Procyon lotor), nine banded armadillo (Dasypus novemcinctus), black tailed jackrabbit (Lepus californicus), and deer mouse (Peromyscus maniculatis). In addition, bison (Bison bison), mountain lion (Felis concolor), and black bear (Ursus americanus) would have been present prehistorically (Davis and Schmidly 1994). Bird species composition in the APE is fairly diverse with numerous breeding, migrant, and wintering species present (Davis and Schmidly 1994). In addition to mammals and birds, Blair (1950) lists at least 75 species of amphibians and reptiles within the Balconian province. 


\section{Chapter 2}

\section{Cultural History}

\section{INTRODUCTION}

The proposed Wurzbach Parkway Extension Project APE lies at the interface of two broad archaeological regions, South Texas and Central Texas. As evident in the artifact assemblages from the San Antonio area, cultural influences fluctuated over time. The following culture history emphasizes central Texas regional patterns as the best fit for the study area, although reference is made to important developments and trends in south Texas.

Several cultural investigations have occurred within the project area including archaeological investigations at the National Register of Historic Places- (NRHP) listed Walker Ranch in the 1970s and 1980s and the proposed Wurzbach Parkway in the 1990s by TxDOT. The early work on the Walker Ranch was conducted by the THC and the Center for Archaeological Research (CAR) at the University of Texas at San Antonio (UTSA). The investigations between the 1970s and 1990s included the excavations of the Walker Ranch site, 41BX180 (A. Fox 1979), Panther Springs Creek site, 41BX228 (Black and McGraw 1985), the Higgins Site, 41BX184 (Black et al. 1998a), and the testing of five sites, 41BX222, 41BX223, 41BX228, 41BX949, and 41BX996 (Black et al. 1998a).

In addition to relying heavily on these projects, the following cultural setting also derives information from several regional syntheses: Black (1989), Collins (2004), Johnson and Goode (1994), and Prewitt (1981), Hester (1989), Hall (1981), and Story (1990). Furthermore, significant archaeological sites near the project area that have contributed important information include the Richard Beene site at Applewhite Reservoir (McGraw and Hindes 1987; Thoms et al. 1996; Thoms and Mandel 1992), the Cibolo Crossing site at Camp Bullis (Kibler and Scott 2000), the Jonas Terrace site in Medina County (Johnson 1995), the Camp Pearl Wheat site in Kerr County (Collins et al. 1990), 41BX1 in Bexar County (Lukowski 1988), 41BX300 in Bexar County (Katz 1987), several sites at Canyon Reservoir (Johnson et al. 1962), and sites from the Cuero I Project area in Gonzales and DeWitt counties (Fox et al. 1974).

The Historic period discussion relies heavily on the Ethnohistory chapter in a volume by Fox et al. (1974), a historic synthesis for the area by Fox (1989), TxDOT's examination of Spanish roads in Texas for the 300th anniversary (McGraw et al. 1998), and Foster's (1995) thorough investigation of Spanish expedition routes through Texas.

For the purposes of this report, the cultural sequence is divided into four periods: Paleoindian, Archaic, Late Prehistoric, and Historic. The Archaic period is subdivided into four subperiods: Early, Middle, Late and Transitional. Following the cultural history of the project area and region, there is a section devoted to the historic resources (i.e., Spanish Roads, NRHP properties, cemeteries, and historic markers) within or near the Wurzbach Parkway Extension Project APE.

\section{Paleoindian Period}

Human occupation of the region is thought to have begun approximately 11,000 years ago. This period correlates with the end of the late Pleistocene, the last ice age in North America. These early Texans are characterized by small but highly mobile bands of foragers who were specialized hunters of Pleistocene megafauna. But Paleoindians probably used a much wider array of resources (Meltzer and Bever 1995:59), including small fauna and plant foods. Faunal remains from Kincaid Rockshelter and the Wilson-Leonard site (41WM235) support this view (Bousman 1998; Collins 1998; Collins et al. 1989). Longstanding ideas about Paleoindian technologies also are being challenged.

Paleoindian occupations of the Central Texas region are represented by surficial and deeply buried sites, rockshelter sites, and isolated artifacts. The WilsonLeonard site (41WM235), 41BX52, and 41BX229 contain stratified Paleoindian deposits (Hester 1989). The lower component at the Wilson-Leonard site contained a Paleoindian burial (Collins et al. 1993). The Vera Daniels site (41TV1324), at the confluence of the 
Colorado River and Barton Creek in Austin, has deeply buried deposits which yielded a Plainview fragment and a possible Clovis preform during limited testing (Ricklis et al. 1991).

Collins (2004) divides the Paleoindian period into early and late subperiods. Two projectile point styles, Clovis and Folsom, are included in the early subperiod. Clovis chipped stone artifact assemblages, including the diagnostic fluted lanceolate Clovis point, were produced by bifacial, flake, and prismatic-blade techniques on highquality and oftentimes exotic lithic materials (Collins 1990). Along with chipped stone artifacts, Clovis assemblages include engraved stones, bone and ivory points, stone bolas, and ochre (Collins 2004; Collins et al. 1992). Clovis points are found evenly distributed along the eastern edge of the Edwards Plateau, where the presence of springs and outcrops of chert-bearing limestone are common (Meltzer and Bever 1995:58). Sites within the area yielding Clovis points and Clovisage materials include Kincaid Rockshelter (Collins et al. 1989), Pavo Real (Henderson and Goode 1991; Collins et al. 2003), and San Marcos Springs (Takac 1991). A probable Clovis polyhedral blade core and a blade fragment were found at the Greenbelt site on Lackland Air Force Base in San Antonio (Houk et al. 1997). Analyses of Clovis artifacts and site types suggest that Clovis peoples were well-adapted, generalized hunter-gatherers with the technology to hunt larger game but not solely rely on it.

In contrast, Folsom tool kits-consisting of fluted Folsom points, thin unfluted (Midland) points, large thin bifaces, and end scrapers - are more indicative of specialized hunting, particularly of bison (Collins 2004). Folsom points have been recovered from Kincaid Rockshelter (Collins et al. 1989) and Pavo Real (Henderson and Goode 1991; Collins et al. 2003).

Postdating Clovis and Folsom points in the archaeological record are a series of dart point styles (primarily unfluted lanceolate darts) for which the temporal, technological, or cultural significance is unclear. Often, the Plainview type name is assigned to these dart points, but Collins (2004) has noted that many of these points typed as Plainview do not parallel Plainview type-site points in thinness and flaking technology. Recent investigations at the Wilson-Leonard site (see Bousman 1998) and a statistical analysis of a large sample of unfluted lanceolate points by Kerr and Dial (1998) have shed some light on this issue. At Wilson-Leonard, the Paleoindian projectile point sequence includes an expanding stem dart point termed Wilson, which dates to ca. 10,000-9,500 B.P. Postdating the Wilson component is a series of unfluted lanceolate points referred to as Golondrina-Barber, St. Mary's Hall, and Angostura, but their chronological sequence is poorly understood. Nonetheless, it has become clear that the artifact and feature assemblages of the later Paleoindian subperiod appear to be Archaic-like in nature and in many ways may represent a transition between the early Paleoindian and succeeding Archaic periods (Collins 2004).

\section{Archaic Period}

The Archaic period for central Texas dates from ca. 8,800 B.P. to $1,300-1,200$ B.P. (Collins 2004) and generally is believed to represent a shift toward hunting and gathering of a wider array of animal and plant resources and a decrease in group mobility (Willey and Phillips 1958:107-108). In the eastern and southwestern United States and on the Great Plains, development of horticultural-based, semisedentary to sedentary societies succeeds the Archaic period. In these areas, the Archaic truly represents a developmental stage of adaptation as Willey and Phillips (1958) define it. For central Texas, this notion of the Archaic is somewhat problematic. An increasing amount of evidence suggests that Archaic-like adaptations were in place before the Archaic (see Collins 2004, 1998; Collins et al. 1989) and that these practices continued into the succeeding Late Prehistoric period (Collins 2004; Prewitt 1981:74). In a real sense, the Archaic period of central Texas is not a developmental stage, but an arbitrary chronological construct and projectile point style sequence. Establishment of this sequence is based on several decades of archaeological investigations at stratified Archaic sites along the eastern and southern margins of the Edwards Plateau. Collins (2004) and Johnson and Goode (1994) have divided this sequence into three parts - early, middle, and late - based on perceived (though not fully agreed upon by all scholars) technological, environmental, and adaptive changes. However, Turner and Hester (1999) and Black (1989) have designated another period at the end of the Archaic, referred to as Transitional Archaic or Terminal Archaic.

\section{Early Archaic}

The Early Archaic period (8,800-6,000 B.P.) around the project area is better documented than the $\mathrm{Pa}$ leoindian period, however a complete understanding of cultural patterns does not yet exist. Early Archaic 
sites are small, and their tool assemblages are diverse (Weir 1976:115-122), suggesting that populations were highly mobile and densities low (Prewitt 1985:217). It has been noted that Early Archaic sites are concentrated along the eastern and southern margins of the Edwards Plateau (Johnson and Goode 1994; McKinney 1981). This distribution may indicate climatic conditions at the time, given that these environments have more reliable water sources and a more diverse resource base than other parts of the region.

Artifact assemblages of the Early Archaic include projectile point styles such as Hoxie, Bulverde, Gower, Wells, Martindale, and Uvalde, as well as unstemmed Early Triangular projectile points. A variety of choppers and gouges, such as the triangular, concave based bifaces known as Guadalupe tools, and the distally beveled Clear Fork unifaces are present in the archaeological record. A variety of expediency tools, often nothing more than utilized flakes, are increasingly present in the Early Archaic (Black 1989).

Construction and use of rock hearths and ovens, which had been limited during late Paleoindian times, became commonplace. The use of rock features suggests that retaining heat and releasing it slowly over an extended period were important in food processing and cooking and reflects a specialized subsistence strategy. Such a practice probably was related to cooking plant foods, particularly roots and bulbs, many of which must be subjected to prolonged periods of cooking to render them consumable and digestible (Black et al. 1997:257; Wandsnider 1997; Wilson 1930). Botanical remains, as well as other organic materials, are often poorly preserved in Early Archaic sites, so the range of plant foods exploited and their level of importance in the overall subsistence strategy are poorly understood. But recovery of charred wild hyacinth (Camassia scilloides) bulbs from an Early Archaic feature at the Wilson-Leonard site provides some insights into the types of plant foods used and their importance in the Early Archaic diet (Collins et al. 1998).

Two excellent Early Archaic site examples are 41DW98, tested by the Cuero I Project (McGraw 1979) and 41GZ203, located by the MIDTEXAS survey (Miller et al. 1996). Site 41DW98 was an open campsite on a fossil floodplain of a perennial tributary of the Guadalupe River. Early Archaic materials recovered during testing include Bulverde points and Clear Fork gouges (Fox et al. 1974). Site 41GZ203 is a buried floodplain site from which two Early Archaic Guadalupe tools were recovered (Miller et al. 1996).

Other significant Early Archaic sites include the Richard Beene site in Bexar County (Thoms and Mandel 1992), the Camp Pearl Wheat site in Kerr County (Collins et al. 1990), and the Jetta Court site in Travis County (Wesolowsky et al. 1976).

\section{Middle Archaic}

Cultural patterns around the project area during the Middle Archaic period (6,000-4,000 B.P.), point toward an increased sedentary population intensively harvesting acorns, Yucca "tuna", and pecans, and hunting small and medium-size game such as deer and turkey. The increase in the number of Middle Archaic sites and burials supports the concept of a larger, more sedentary population (Black and McGraw 1985; Prewitt 1981:73; Weir 1976:124, 135). Macrobands may have formed at least seasonally, or more small groups may have used the same sites for longer periods (Weir 1976:130-131).

Sites of the Middle Archaic are numerous and often large in size. Burned rock middens are found at many sites with Middle and Late Archaic components in central Texas while middens decrease in frequency to the south and east of central Texas. Cemeteries with large numbers of interments appear late in the Middle Archaic (Turner and Hester 1999:57). Lithic procurement sites and open campsites on terraces and floodplains date to the Middle Archaic from site 41BX66 along Loop 1604 and the Cuero I project along the Guadalupe River (Fox et al. 1974).

The development of burned rock middens toward the end of the Middle Archaic suggests a greater reliance on plant foods, although tool kits still imply a considerable dependence on hunting (Prewitt 1985:222-226). Middle Archaic projectile point styles include Bell, Andice, Taylor, Baird, Nolan, and Travis. Other artifacts from the Middle Archaic are choppers, gouges, and expediency tools such as the small bifacial and unifacial Clear Fork tools. Grinding stones and bases, referred to as manos and metates, show up in Middle Archaic artifact assemblages as well as a number of perforators, drills, and awls. Chipped, polished, and ground stone artifacts are common in central Texas and the surrounding regions. Less frequently encountered artifacts include tools and ornaments of bone, antler, and marine shell (Turner and Hester 1999:57). 
Bell and Andice points reflect a shift in lithic technology from the preceding Early Archaic Martindale and Uvalde point styles (Collins 2004). Johnson and Goode (1994:25) suggest that the Bell and Andice darts are parts of a specialized bison-hunting tool kit. They also believe that an influx of bison and bison-hunting groups from the Eastern Woodland margins during a slightly more mesic period marked the beginning of the Middle Archaic. Though no bison remains were recovered or present, Bell and Andice points and associated radiocarbon ages were recovered from the Cibolo Crossing site (Kibler and Scott 2000) and adjacent to the project area at the Panther Springs Creek site (Black and McGraw 1985) in Bexar County. Bison disappeared as more-xeric conditions returned during the late part of the Middle Archaic. Later Middle Archaic projectile point styles represent another shift in lithic technology (Collins 2004; Johnson and Goode 1994:27). At the same time, a shift to more-xeric conditions saw the burned rock middens develop, probably because intensified use of a specific resource (geophytic or xerophytic plants) or resource patches meant the debris of multiple rock ovens and hearths accumulated as middens on stable to slowly aggrading surfaces, as Kelley and Campbell (1942) suggested many years ago. Johnson and Goode (1994:26) believe that the dry conditions promoted the spread of yuccas and sotols, and that it was these plants that Middle Archaic peoples collected and cooked in large rock ovens.

\section{Late Archaic}

During the succeeding Late Archaic period (4,000 B.P. to $1,300-1,200$ B.P.), populations continued to increase (Prewitt 1985:217). As evidenced by stratified Archaic sites such as Loeve-Fox, Cibolo Crossing, and Panther Springs Creek, the Late Archaic components contain the densest concentrations of cultural materials of all these periods. Establishment of large cemeteries along drainages also suggests certain groups had strong territorial ties (Story 1985:40).

Middle Archaic subsistence technology, including the use of rock and earth ovens, continues into the Late Archaic period. Collins (2004) states that, at the beginning of the Late Archaic period, the use of rock ovens and the resultant formation of burned rock middens reached its zenith and declined during the latter half of the Late Archaic. There is, however, mounting chronological data that midden formation culminated much later and that this high level of rock and earth oven use continued into the early Late Prehistoric period (Black et al. 1997:270-284; Kleinbach et al. 1995:795). A picture of prevalent burned rock midden development in the eastern part of the Central Texas region after 2,000 B.P. is gradually becoming clear. This scenario parallels the widely recognized occurrence of post-2,000 B.P. middens in the western reaches of the Edwards Plateau (see Goode 1991).

The use of rock and earth ovens (and the formation of burned rock middens) for processing and cooking plant foods suggests that this technology was part of a generalized foraging strategy. Considering the amount of energy involved in collecting plants, constructing hot rock cooking appliances, and gathering fuel, the caloric return of most plant foods is relatively low (Dering 1999). This suggests that plant foods were part of a broad-based diet (Kibler and Scott 2000:134) or part of a generalized foraging strategy, an idea Prewitt (1981) put forth earlier. At times during the Late Archaic, this generalized foraging strategy appears to have been marked by shifts to a specialized economy focused on bison hunting (Kibler and Scott 2000:125-137). Castroville, Montell, and Marcos dart points are elements of tool kits often associated with bison hunting (Collins 1968). Archaeological evidence of this association is seen at Bonfire Shelter in Val Verde County (Dibble and Lorrain 1968), Jonas Terrace (Johnson 1995), Oblate Rockshelter (Johnson et al. 1962:116), John Ischy (Sorrow 1969), and at the Panther Springs Creek site (Black and McGraw 1985).

Late Archaic cemeteries such as Loma Sandia, site 41BX1, and isolated burials carry on mortuary traditions begun in the Middle Archaic (Steele and Olive 1989). Mortuary practices became standardized, suggesting that relatively large populations were becoming territorial. Evidence of conflict is seen in the increase in skeletal remains with projectile point wounds. Grave goods become more common and indicate contact with adjacent regions (Story 1990). At the Morhiss site, 41VT1, the Works Progress Administration (WPA) exposed over 250 burials, 40 hearths, and numerous cache pits (Campbell 1976). A variety of Archaic and Late Prehistoric materials was recovered with the burials including many shell tools and ornaments. In the Brazos drainage, over 65 sites with 340 burials are known. The Colorado drainage has over 62 sites with 174 burials, and the Guadalupe drainage has over 15 sites with 328 burials. Most of the sites are best characterized as cemeteries though a significant number of individual burials also occur (Steele and Olive 1989). 


\section{Transitional Archaic}

As Collins (2004) notes, diverse and comparatively complex archaeological manifestations toward the end of the Late Archaic attest to the emergence of kinds of human conduct without precedent in the area. This period $(2,250-1,250$ B.P.), referred to as the Transitional Archaic (Turner and Hester 1999) or Terminal Archaic (Black 1989), is not recognized by all researchers. Other chronologies extend the Late Archaic to 1,200-1,250 B.P. (Collins 2004; Johnson and Goode 1994) to encompass this later subperiod. Johnson et al. (1962) originally designated the Transitional Archaic as a subperiod of the Archaic because of the similarities between the latest dart point types and the earliest arrow point types. Since then, however, the designation has failed to be universally accepted by researchers. In two recent chronologies for central Texas, Collins (2004) does not include the Transitional as a subperiod of the Archaic, and Johnson and Goode (1994) separate the Late Archaic into two subperiods designated Late Archaic I and Late Archaic II. The Transitional Archaic, as it is used here, closely corresponds to Johnson and Goode's (1994) Late Archaic II, but begins after the appearance of Marcos points, not with it. In this scheme, the Transitional Archaic coincides with the last two style intervals recognized by Collins for the Late Archaic subperiod.

During the Transitional Archaic, smaller dart point forms such as Darl, Ensor, Fairland, and Frio were developed (Turner and Hester 1999). These points were probably ancestral to the first Late Prehistoric arrow point types and may have overlapped temporally with them (Hester 1995; Houk and Lohse 1993).

Several researchers believe that the increased interaction between groups at the end of the Late Archaic was an important catalyst for cultural change (Collins 2004; Johnson and Goode 1994). This change may have included increased regional stress and conflict between groups as interaction became more frequent (Houk et al. 1997). In Bexar County, for instance, researchers noted a distinct shift in settlement patterns during this period (Houk et al. 1997). Groups began to use hilltops as camps rather than just lithic procurement locations. These elevated locations would have provided points from which to observe game and other groups of humans as they moved through the surrounding creek valleys and upland prairies (Houk et al. 1997).
Overall, the Archaic period represents a hunting and gathering way of life that was successful and that remained virtually unchanged for more than 7,500 years. This notion is based in part on fairly consistent artifact and tool assemblages through time and place and on resource patches that were used continually for several millennia, as the formation of burned rock middens shows. This pattern of generalized foraging, though marked by brief shifts to a heavy reliance on bison, continued almost unchanged into the succeeding Late Prehistoric period.

\section{Late Prehistoric Period}

Introduction of the bow and arrow and, later, ceramics into central Texas marked the Late Prehistoric period (1,250-350 в.P.). Population densities dropped considerably from their Late Archaic peak (Prewitt 1985:217). Subsistence strategies did not differ greatly from the preceding period, although bison again became an important economic resource during the latter part of the Late Prehistoric period (Prewitt 1981:74). Use of rock and earth ovens for plant food processing and the subsequent development of burned rock middens continued throughout the Late Prehistoric period (Black et al. 1997; Kleinbach et al. 1995:795). Horticulture came into play very late in the region but was of seemingly minor importance to overall subsistence strategies (Collins 2004).

The project area occupies an intermediate cultural area that was influenced by surrounding regions during the Late Prehistoric. The Austin and Toyah cultures from central Texas, and possibly, sedentary Woodland cultures from east and southeast Texas affected the project area during the Late Prehistoric period (Black 1989; Story 1990). The Austin Phase (1,250-650 B.P.) like the cultures before it relied on a hunting and gathering subsistence with more of an emphasis on gathering (Prewitt 1981:83). The Toyah Phase (650-200 B.P.) relied more on bison procurement (Prewitt 1981:84). The Woodland cultures from east Texas harvested domesticated crops like maize and lived in sedentary villages. A combination of these cultural patterns and their associated artifact assemblages can be seen in the Late Prehistoric archaeological record for the project area.

Around 1,000-750 B.P., slightly more-xeric or droughtprone climatic conditions returned to the region, and bison came back in large numbers (Huebner 1991; Toomey et al. 1993). Using this vast resource, Toyah peoples were equipped with Perdiz point-tipped ar- 
rows, end scrapers, four-beveled-edge knives, and plain bone-tempered ceramics. Toyah technology and subsistence strategies represent a completely different tradition from the preceding Austin phase. Collins (2004) states that formation of burned rock middens ceased as bison hunting and group mobility obtained a level of importance not witnessed since Folsom times. Although the importance of bison hunting and high group mobility hardly can be disputed, the argument that burned rock midden development ceased during the Toyah phase is tenuous. A recent examination of Toyah-age radiocarbon assays and assemblages by Black et al. (1997) suggests that their association with burned rock middens represents more than a "thin veneer" capping Archaic-age features. Black et al. (1997) claim that burned rock midden formations, although not as prevalent as in earlier periods, was part of the adaptive strategies of Toyah peoples.

In the project area, the cultural pattern has been interpreted to be one of semi-sedentism with a focus on hunting medium-sized game and harvesting seasonal terrestrial and marine food sources. Pottery introduced from adjacent cultural regions first appeared in the project area during the Late Prehistoric period (Black 1989; Prewitt 1981:84).

Artifact assemblages include Scallorn, Perdiz, Talco, and Granbury projectile points; worked stone; thermally altered stone; hematite; bone; and shell. The points are associated with the use of the bow and arrow in the region, probably introduced here sometime around 1,350-1,150 B.P. Talco points are typically found in northeast Texas and may indicate contact with that area (Hall 1981). Such contact correlates with the Transitional Archaic/Early Late Prehistoric data at 41AU36 from Allens Creek. Contact with east Texas is postulated at 41AU36 based on the presence of east Texas Gary points and pottery (Hall 1981).

\section{Historic Period}

The Historic Period (A.D. 1630 to present) in Texas roughly begins when Europeans first entered the region. From just after A.D. 1550 to the late 1600s, European journeys into the area were rare. Motivated primarily by European politics, but also by evangelization and the slave trade, the first Europeans into the project area were probably Spanish explorers and missionaries (Cecil and Greene 2004; Foster 1995). With the exception of these Spanish entradas or expeditions, Texas during the early Historic Period was claimed by Spain but basically remained without an established Spanish presence until around A.D. 1700 (Foster 1995; Taylor 1996).

\section{Spanish EnTradas}

Motivated initially by indigenous Indian's requests for the establishment of missions and later by the fear of French expansion, the Spanish explored and established missions in eastern and central Texas during the latter part of the seventeenth century (Foster 1995). The first overland Spanish entradas were led by Governor Alonso de Léon (1689 and 1690) (Foster 1995). These two expeditions passed south and east of the San Antonio area. The first Spanish entrada to cross through the area was led by Governor Domingo Terán de los Ríos, which passed through present day San Antonio from 1691-1692 (Cecil and Greene 2004; Foster 1995:51-75). Similarly, subsequent expeditions (Governor Gregorio de Salinas Varona in 1693, Fray Isidro de Espinosa, Fray Antonio de Olivares, and Captain Pedro de Aguirre in 1709, and Captain Domingo Ramón in 1716) all passed through or near San Antonio (Foster 1995). The expedition of Governor Martín de Alarcón in 1718 was undertaken to establish a mission and presidio on the San Antonio River and to resupply the missions in east Texas (Foster 1995:127-143). This expedition paralleled the Guadalupe River, near Gonzales, Texas (Foster 1995:128). Several expeditions (Governor Marqués de San Miguel de Aguayo from 1721-1722, Brigadier Pedro de Rivera in 1727, the Marqués de Rubí in 1767, and Fray Gaspar José de Solís in 1768) paralleled the San Antonio River (Foster 1995:145-195). These entrada routes were the genesis of the Spanish road system throughout Texas. These Spanish roads have been incorporated into the Texas highway network that is in use today (Foster 1995:1).

\section{Spanish Missions}

There is little available information on aboriginal groups and their ways of life except for the fragmentary data Spanish missionaries gathered. The central Texas area was reportedly inhabited by several aboriginal groups, which included Tonkawa, Lipan Apache, Comanche, Jumano, Catqueza, and Karankawa (Cecil and Greene 2004; Foster 1995). In the San Antonio area and areas to the south, these groups have been referred to collectively as Coahuiltecans because of an assumed similarity in way of life, but many individual groups may have existed (Campbell 1988). Particular Coahuiltecan groups, such as the Payaya and Juanca, 
have been identified as occupying the San Antonio area (Campbell 1988). The Payaya and Pampopa Indians were two groups for whom San Antonio-area missions were established, although early missions also included numerous groups from the Brazos, Colorado, and San Antonio river valleys. The beginning of the late seventeenth and early eighteenth centuries was an era of more-permanent contact between Europeans and Native Americans as the Spanish moved northward out of Mexico to establish settlements and missions on their northern frontier (see Castañeda [1936-1958] and Bolton [1970] for extended discussions of the mission system and Indian relations in Texas and the San Antonio area).

The Payaya were one of the aboriginal groups that made early contact with the Spanish in San Antonio. The Payaya sought protection from the Apache at newly established Spanish missions, settlements, and presidios like the Mission San Antonio de Valero (the Alamo) and the Presidio San Antonio de Bexar founded on May 5, 1718, by Don Martín de Alarcón near the headwaters of San Pedro Creek (Chipman 1992:117). The Spanish in turn, actively recruited the Native Americans to help bolster their settlements on this northern frontier in response to French incursions led by La Salle. The Spanish presence around San Antonio is best seen as part of the complex European political picture of the time.

The Spanish Missions also served as a point of contact between the southward-advancing Apaches and the Spanish, with native groups often caught in between. Disease and hostile encounters with Europeans and intruding groups such as the Apache were already wreaking their inevitable and disastrous havoc on native social structures and economic systems by this time.

Establishment of the mission system in the first half of the eighteenth century to its ultimate demise around 1800 brought the peaceful movement of some indigenous groups into mission life, but others were forced in or moved in to escape the increasing hostilities of southward-moving Apaches and Comanches. Many of the Payaya and Juanca lived at Mission San Antonio de Valero, but so many died there that their numbers declined rapidly (Campbell 1988:106, 121-123). By the end of the mission period, European expansion and disease and intrusions by other Native American peoples had decimated many Native American groups. The small numbers of surviving Payaya and Juanca were acculturated into mission life. The last references to the Juanca and Payaya were recorded in 1754 and 1789 , respectively, in the waning days of the mission (Campbell 1988:98, 123). By that time, intrusive groups such as the Tonkawa, Apache, and Comanche had moved into the region to fill the void. Outside of the missions, few sites attributable to these groups have been investigated. To complicate matters, many aboriginal ways of life endured even after contact with the Spanish. For example, manufacture of stone tools continued even for many groups settling in the missions (D. Fox 1979).

\section{Spanish Texas Rebellions}

New Spain and Spanish Texas around the beginning of the nineteenth century was a turbulent time of numerous insurrections and conflicts (Campbell 2003). These conflicts primarily arose over internal political struggles between the peninsulares (natives of Spain) and the criollos (those of Spanish blood born in America) (Campbell 2003:89).

One of the revolutions occurred in San Antonio on January 21, 1811 when retired militia captain Juan Bautista de las Casas and some co-conspirators captured Governor Salcedo (Campbell 2003:90; Richardson et al. 1981:41). Las Casas proclaimed himself leader of the revolutionary government and then set about arresting royalists and confiscating their property (Campbell 2003:90). This revolution lasted 39 days when a royalist counterrevolutionary force led by Juan Manuel Zambrano overthrew Las Casas with Governor Salcedo resuming control of San Antonio (Campbell 2003:91).

Other concerns at this time for New Spain and Spanish Texas were the filibusters or Anglo-American intruders with political designs (e.g., Philip Nolan in 1801, Louis Aury in 1816, and James Long in 1821) (Campbell 2003; Richardson et al 1981). A filibuster incursion of note to the area was the Gutiérrez-Magee expedition in 1812 (Campbell 2003; Richardson et al. 1981). José Bernardo Gutiérrez de Lara and Augustus William Magee led an expedition into Texas from Louisiana in order to forcibly take control of Texas from Spain. From August of 1812 to April of 1813, the Gutiérrez-Magee expedition traveled westward across Texas capturing Nacogdoches, Trinidad de Salcedo, and La Bahía. On March 28, 1813 near the juncture of Salado Creek and the San Antonio River, the Battle of Rosillo was fought between Spanish royalists and the republican army of the Gutiérrez-Magee expedition (Campbell 2003:91-92; Richardson et al. 
1981:42). The republican army defeated the Spanish royalist army and on April 1, 1813 Gutiérrez entered San Antonio and Governor Salcedo and about a dozen officers surrendered (Campbell 2003:91-92; Richardson et al. 1981:42).

On April 6, 1813 in San Antonio, Gutiérrez proclaimed a declaration of independence, forming the first republic of Texas with Gutiérrez as "President Protector of the State of Texas" (Campbell 2003:93). However, for a variety of reasons Gutiérrez's reign was short, lasting about three months when General José Álvarez de Toledo y Dubois deposed him (Campbell 2003:93; McGraw et al. 1998; Richardson et al. 1981; Thonhoff 2005).

Spain responded to the rebellion by sending General Joaquín de Arredondo and his army to San Antonio in order to crush the rebels. Arredondo and his army left Laredo in early August and marched to San Antonio along the Laredo Road. Toledo and the republican army intercepted the Spanish army south of the Medina River in order to spare San Antonio from the impending conflict. Thus, on August 18, 1813, the two armies met and fought the Battle of the Medina, which is sometimes referred to as, "the bloodiest battle ever fought on Texas soil" (Campbell 2003:93; Thonhoff 2005). General Arredondo's forces consisted of 1,830 soldiers while Toledo's republican army contained 1,400 Anglos, Tejanos, Indians, and former royalists (Campbell 2003; Thonhoff 2005).

At the end of the conflict, the Spanish army overwhelmingly defeated the republican army by killing all but about 100 soldiers, which escaped. The bodies of the republican soldiers were left unburied until 1822 (nine years after the battle) when the first governor of Texas, José Félix Trespalacios, in the newly formed Republic of Mexico, had the bones collected and buried at the battlefield (Thonhoff 2005). The probable location of these events, site 41AT109, is near the confluence of Galvan and Gallinas Creeks and was described by J. L. Berlandier as La Loma de San Cristóbal (McGraw et at. 1998).

The devastating defeat of the republican army at the Battle of the Medina ended the Gutiérrez-Magee expedition and Texas' first republic (Thonhoff 2005). This battle is notable in that it was one of the largest in North America up to the Civil War, which had consequences that affected the demography and economic development of the region for years after the conflict
(McGraw et al. 1998:285). However, possibly due to the tumultuous times of the era and the outcome of the battle, it has largely been forgotten and the exact location of the battle and the burial site lost (McGraw et al.1998; Thonhoff 2005).

Although rebellion and revolt had been suppressed, the feelings of discontent between the upper and lower classes and the dissatisfaction with Old Spain remained (Richardson et al. 1981). Finally, in early 1821, the conservative upper classes of Mexico represented by Agustín de Iturbide met with rebel leader Vicente Guerrero and negotiated the Plan of Iguala on February 24, 1821. Briefly, this plan proclaimed New Spain independent from Old Spain, which was to be governed by a constitutional monarchy that protected the Catholic Church and racial equality (Richardson et al. 1981:52). Thus, after the signing of the Treaty of Córdoba by Viceroy Juan O'Donojú accepting this plan, Spanish Texas was now Mexican Texas (Campbell 2003:97; Richardson et al. 1981:52).

\section{Texas Settlement and Independence}

After Mexico gained independence from Spain, the newly formed country used a policy of land grants to attract settlers into the area, including Anglos from the United States, to help inhabit the sparsely populated northern regions of Mexico. During the 1820s, Empresario,or colonization agent Green DeWitt, obtained grants from the Mexican government to settle 400 families along the Guadalupe, San Marcos, and Lavaca rivers (Baumgartner and Vollentine 2007; Campbell 2003; Richardson et al. 1981; Smyrl 2007). Early settlement of the colony, known as the DeWitt's Colony, migrated between Gonzales and Lavaca finally settling around Gonzales due to harassment from Comanches and property boundary disputes with settlers of the De León grant (Richardson et al. 1981; Smyrl 2007). Subsequent settlement in the area centered on waterways (Smyrl 2007).

Because of a request from an increasing population seeking assistance from Indian raids, the Mexican government sent a 6-pound cannon to Gonzales in 1831 for their protection (Baumgartner and Vollentine 2005). Subsequently, the attendance by delegates of DeWitt's Colony at the conventions for the separation in statehood from Coahuila of 1832 and 1833 and the Consultation of 1835 were viewed as disloyalty and the Mexican government sent forces to retrieve the cannon (Baumgartner and Vollentine 2005; Campbell 
2003; Richardson et al. 1981). On October 2, 1835, Lieutenant Francisco Castañeda and 100 dragoons and about 150 Texians converged about 1 mile east of present day Cost, Texas (Baumgartner and Vollentine 2007; Campbell 2003; Richardson et al. 1981). This conflict was brief, resulting in one shot from the Gonzales "come and take it" cannon and the beginning of the Texas revolution (Baumgartner and Vollentine 2005; Campbell 2003; Richardson et al. 1981).

\section{Republic of Texas Era}

After the events that transpired during the War of Texas Independence, San Antonio and central Texas continued to grow. Population estimates drawn from tax rolls suggest that the population in Texas from 1836-1846 increased by 269 percent (Campbell 2003:159). It was during this time that the phrase "Gone to Texas" became legendary and the initials G.T.T. were chalked on doors in the southern United States (Campbell 2003:159; Handbook of Texas Online 2007).

Among those to move into central Texas were German immigrants who came in to the area as a result of the Society for the Protection of German Immigrants in Texas. This society, founded in 1845 by Prince Carl of Solms-Braunfels, brought a massive influx of German immigrants into central Texas (Fox et al. 1997:2). While many of these new settlers founded German towns such as Castroville, New Braunfels, and Fredericksburg, several chose to stay in the established town of San Antonio and offered the area many industries, which it lacked such as breweries and tanneries.

On December 29, 1845 Congress signed the Texas Admission Act, which culminated after several years of annexation debate. And on February 19, 1846 members of the newly formed state government and leaders of the Republic conducted a ceremony in front of the Capitol at Austin marking Texas' official annexation into the Union and the end of the Republic of Texas (Campbell 2003:186; Miller and Faux 1997:78).

\section{Civil War in Texas}

Although Texas' involvement in the Civil War is beyond the scope of discussion here, Texas played an integral part for the confederacy. The citizens of Texas overwhelmingly approved of the secession from the Union. In a vote held on February 23, 1861, 75 percent of the voters favored the secession (Campbell 2003:244).
The feeling of secession held by the majority may be attributed to the immigrants of Texas primarily coming from southern, slave-holding states (Campbell 2003:207). These immigrants brought with them the institution of slavery and created an economy and society based on agriculture (Campbell 2003:207). Thus, the abolition of slavery would have drastically affected Texas. The Declaration of Causes issued by the Texas legislature in 1861 declared that the end of slavery would, “...bring inevitable calamities..." for the 15 slave holding states (Campbell 2003:246).

\section{Post-Civil War Era}

Subsequent to the Civil War, Texas entered the Reconstruction period. To begin reconstruction, federal troops, in part, had to spread the word of the Emancipation Proclamation (Campbell 2003:268). In Galveston on June 19, 1865 General Gordon Granger and the Union army spread the word of the slaves' emancipation (Campbell 2003:268). Thus, this day became known as Juneteenth and has been celebrated by Texas African Americans ever since (Campbell 2003:268).

One invention that had an affect on Texas and its economy during this time was barbed wire. Barbed wire, first demonstrated in 1871, enabled ranchers to alter land and cattle control to a less-intrusive, more profitable plan, and brought additional commerce and trade to central and south Texas (McCallum and Owens 2007). Though barbed wire was one of the largest influences on Texas in general, the most influential invention in the region was the railroad.

The first railway came through San Antonio in 1877, bringing with it a plethora of job opportunities and commercial ventures. The railroad brought about a large shift in settlement patterns, as the eastern neighborhoods which were once multi-ethnic, became popular among African-Americans who worked as porters, mechanics, and loading crew for the growing railways. Wealthy citizens moved from the noise and traffic of downtown to quieter suburbs in the north and west. Through the 1880 s and 1890 s, as the economy of the city prospered through tourism, the population of the city doubled from 53,321 to over 100,000 people (Fox et al. 1997:31).

By the 1880 s to 1900 s the area began to recover economically because of improved transportation and migration of people from other states and countries and continued throughout the early twentieth century with trade, transportation, and tourism continuing to bring 
economic prosperity to San Antonio. The establishment of Fort Sam Houston and the activity surrounding World War I and World War II kept the railway system active and commercial activity in the east prospered.

Through the remainder of the twentieth century, San Antonio expanded rapidly but the downtown portion retained the city plan established in the nineteenth century. A major preservation program was initiated in 1976 in conjuncture with new planning laws emphasizing the establishment of historic districts and national landmarks. Thus, most of the downtown area today retains its late nineteenth century appearance and configuration, while accommodating modern conveniences such as plumbing, electricity, and the automobile.

\section{Historic Resources In or Near the Project Area}

The APE traverses a portion of the Walker Ranch National Register District; however, all contributing resources within the APE were previously mitigated by TxDOT in the 1990s. Walker Ranch was established by Captain Edward Higgins in the 1840s. He used it to settle a debt with Charles F. de Ganahl in 1853. The original Higgins ranch and adjacent acquisitions remained in the Ganahl/Walker family until 1972. At the ranch were two stone gate pillars engraved with a cross, the date 1786, and several brands. These appear to date the ranch to the Spanish Colonial period, but no associated artifacts have ever been encountered (A. Fox 1979). Walker Ranch was listed on the NRHP in 1975. The NRHP District is comprised of the ruins of two 2-room structures, cisterns, extensive stone walls, and 16 archaeological sites.

Other historic resources near the Wurzbach Parkway Extension Project APE besides Walker Ranch include the Coker community and the Coker Methodist Cemetery, where the graves of John "Jack" Coker and Jefferson Davis Smith bear historical markers.

The Coker community was founded by Jack and his brother Joseph on acreage Jack was awarded for his military service at the Battle of San Jacinto in Texas' War for Independence. Historical Marker 935 was erected in 1968 at Jack's grave and reads:

John “Jack” Coker (May 10, 1789-Jan. 4, 1861) Came from South Carolina to Texas in 1834. Served in Battle of San Jacinto in Texas War for Independence, 1836. Was one of a party with "Deaf" Smith that destroyed Vince's Bridge near Pasadena. This deed may have kept Santa Anna's army from retreat or reinforcement, thus insuring Texas victory. In recognition, the Legislature of Texas awarded to Coker 1,920 acres, where he and his brother Joseph founded Coker community.

Jefferson Davis Smith and his brother Clint were captured while herding sheep along Cibolo Creek between San Antonio and Boerne in 1871 (Lich 2007). They were held captives by Lipan and Comanche Indians before being returned to their families. Consequently, they gained fame as "frontier" celebrities and performers of the Old West. Both brothers were also trail drivers, cowboys, and ranchers (Lich 2007). Historical Marker 4960 was erected in 1993 at Jefferson's grave and reads:

Jefferson (Jeff) Davis Smith, son of Henry M. and Fanny (Short) Smith, was born in Kendall County, Texas. Jeff, Age 9, and his brother Clint, age 11, were kidnapped by Lipan and Comache Indians while herding sheep near their home in 1871. Jeff was reportedly bought by Apache Chief Geronimo and made to join his tribe. Mexican bandits captured him to return him to his family for a $\$ 1,000$ reward about 1878. He married Julia Harriet Reed in 1894 and moved to San Antonio. 


\section{Chapter 3}

\section{MeTHODS}

\section{BACKGROUNd ReVIEW}

SWCA conducted an intensive background archaeological literature and records search of the Wurzbach Parkway Extension Project APE in February 2007. An SWCA archaeologist searched the Texas Archeological Research Laboratory (TARL) files and the Texas Historic Sites Atlas (Atlas) online database for any previously recorded surveys and historic or prehistoric archaeological sites located in or near the APE.

In addition to identifying recorded archaeological sites, the review included the following types of information on the Atlas: NRHP properties, State Archeological Landmarks (SAL), Official Texas Historical Markers (OTHM), Registered Texas Historic Landmarks (RTHL), cemeteries, and local neighborhood surveys.

The archaeologist also examined the following sources: the Soil Survey of Bexar County, Texas, the Geologic Atlas of Texas, and the Castle Hills and Longhorn U.S. Geological Survey (USGS) 7.5-minute topographic maps of the APE. A review of aerial photographs was conducted to assist in determining whether any standing structures or features are located within or adjacent to the APE. Finally, SWCA examined files at TxDOT for any and all information regarding previous Wurzbach investigations and site information.

\section{Field Methods}

The cultural resources survey was conducted to determine the nature, extent, and if possible, significance of any cultural resources located within the APE, according to 13 TAC 26.20. As the background review made it clear, the majority of the APE had been extensively investigated by archaeologists in the late 1980s and early 1990s. The level of SWCA investigations was designed to confirm previous findings and investigate sites or lands previously unexplored. The survey consisted of three to four archaeologists walking the entire length of the APE, access permitting. Archaeologists utilized shovel tests and artificial and natural exposures to determine the presence and potential for cultural resources. The survey was conducted in formal 30-m transects.

SWCA conducted intensive survey in areas where sites had been previously documented, where alluvial soils were mapped, and where urban disturbances appeared minor. The survey mainly included the area between Blanco and Jones Maltsberger roads. The goal in these areas was to relocate sites within the APE, document their current conditions, and to assess the potential need for further investigation such as backhoe trenches where alluvial soils were present.

Disturbed, rocky upland portions of the project area were examined at a reconnaissance level only. Reconnaissance-level survey was primarily conducted west of U.S. 281 based on the levels of effort of previous surveys, observed disturbances, and existing residential and infrastructural development. Overall, SWCA archaeologists walked 100 percent of the APE for which right of entry had been granted from Blanco Road to Jones Maltsberger Road. (Interpark Associates LTD and Coker United Methodist Church did not allow access to their properties, which are between West Avenue and U.S. 281.)

A reconnaissance-level survey was conducted between Jones Maltsberger and Wetmore roads, an area previously investigated by archaeologists on several occasions and where predominately landfills, pits, and quarries are mapped (Fisher 1983). Additionally, in this area, site 41BX949 was surveyed at the reconnaissance level because previous testing (Potter and Black 1995) produced an extremely low frequency of artifacts in six backhoe trenches and nine shovel tests. Potter and Black (1995:13) were unable to define meaningful site limits or even confirm the existence of a discrete archaeological site at this location.

At sites 41BX947 and 41BX948, SWCA archaeologists relocated the previous investigations and determined the area for which access was restricted in the 1990s. Backhoe trenches and shovel tests were used to investigate these previously unsurveyed areas and 
further explore the contents and structure of the sites. SWCA evaluated the sites' eligibility for the NRHP, or for designation as an SAL, and the need for further testing-level work.

Had any newly discovered sites been identified, they would have been assessed in regard to potential significance so that recommendations could be made for proper management (avoidance, non-avoidance, or further work). Additional shovel tests would have been conducted per THC standards at any discovered sites to define horizontal and vertical boundaries. Appropriate State of Texas Archaeological Site Data Forms would have been filled out for each site discovered during the investigations. A detailed plan map of each site would have been produced with locations plotted on USGS 7.5-minute topographic maps and relevant project maps.

SWCA conducted a non-collection survey. Artifacts were tabulated, analyzed, and documented in the field, but not collected. Temporally diagnostic artifacts were described in detail and photographed in the field. Only especially rare artifacts or discoveries were collected, which for this survey includes two Pedernales projectile points that were encountered within the boundaries of 41BX228.

\section{General SUbSURFACE MEthods}

\section{Shovel Testing}

Shovel testing was primarily used when the APE included upland topography with low potential for deeply buried sites. Shovel tests were excavated in 20 -cm arbitrary levels to $1 \mathrm{~m}$ in depth, or to culturally sterile deposits, whichever came first. The matrix was screened through $1 / 4$-inch mesh. The location of each shovel test was plotted using a global positioning system (GPS) receiver, and each test was recorded on appropriate project field forms. Areas with previously recorded sites or other cultural resources revealed in the archival research required additional shovel testing to explore the nature of the cultural deposits. THC survey standards call for 16 shovel tests per mile of project area or one per 2-3 acres.

\section{Backhoe Trenching}

Portions of the project include topographic settings that had the potential for deeply buried archaeological sites, namely the Salado Creek floodplain and associated alluvial terraces. The primary method for quickly and efficiently exploring these areas was backhoe trenching. In these areas, trenches were placed approximately 100-300 m apart, with tighter intervals, if needed. In the floodplain setting between U.S. 281 and Jones Maltsberger Road, the trenching interval was 1.4 trenches per two acres.

Trench placement was based on the level of disturbance within the project area, the location of buried utilities, the location of any impacted areas, and the preservation potential for archaeological sites. Backhoe trenches were excavated to a depth sufficient to determine the presence/absence of buried cultural materials and allow the complete recording of all features and geomorphic information to depths of project's impacts. The results for each trench were recorded on individual forms.

Generally, trenches were $2 \mathrm{~m}$ deep, $8 \mathrm{~m}$ long, and 1.5 $\mathrm{m}$ wide. An experienced archaeologist monitored all trenching while excavations were underway. Stratigraphic profile drawings with soils descriptions were recorded for each trench by an experienced archaeologist. No features were encountered during trenching. A column of soil was excavated and screened down one side of select trenches. The columns were roughly $30 \times 30 \mathrm{~cm}$ in size, extending from the ground surface to the base of the trench. Soil from the column was removed in 20-cm levels and screened through $1 / 4$-inch hardware screen mesh.

All work was performed in accordance with OSHA (29 CFR Part 1926) and the Texas Trench Safety Act (H. B. 1569). Appropriate measures were taken for any trenches that exceeded $2 \mathrm{~m}$ in depth, utilizing shoring or the stepping back of sidewalls to insure that all Occupational Safety and Health Administration (OSHA) protocols were followed. The entire process was thoroughly photographed. All trenches were backfilled and leveled upon completion of excavation and recording. 


\section{Chapter 4}

\section{Previous Investigations and Recorded Archaeological Sites}

\section{Previous Investigations}

The background review revealed that the vast majority of the 5.3-mile parkway APE has been previously surveyed and numerous archaeological sites have been documented both within and adjacent to the APE (Black and McGraw 1985; Carpenter and French 2003; Fox 1979; Hester 1974; Hudson et al. 1974; Potter 1980; Scurlock and Hudson 1973). In addition, archaeological testing and data recovery work has also been conducted on several sites found along the Wurzbach Parkway Extension Project APE (Black 1992; Black et al. 1998a; Potter and Black 1995). TxDOT also cleared a portion of the overall parkway project between Northwest Military Highway and Blanco Road (THC concurrence letter dated July 5, 2000).

Several cultural investigations beyond the survey level have occurred within the project area including archaeological investigations at the NRHP-listed Walker Ranch in the 1970s and 1980s and the proposed Wurzbach Parkway in the 1990s by TxDOT. The early work on the Walker Ranch was conducted by the THC and CAR of UTSA. The investigations between the 1970s and 1990s included the excavations of the Walker Ranch site, 41BX180 (Fox 1979), Panther Springs Creek site, 41BX228 (Black and McGraw 1985), the Higgins Site, 41BX184 (Black et al. 1998a), and the testing of five sites, 41BX222, 41BX223, 41BX228, 41BX949, and 41BX996 (Black et al. 1998b).

TARL worked in conjunction with TxDOT in the 1990s to survey the Wurzbach Parkway right-of-way (ROW) from Lockhill-Selma Road to the parkway's intersection with IH 35. Their investigations included testing of 41BX184, 41BX222, 41BX223, 41BX228, 41BX947, 41BX948, 41BX949, 41BX996, 41BX1062, and 41BX1063 (Black et al. 1998a; Potter and Black 1995; Black et al. 1998b). Data recovery investigations were also accomplished at 41BX184, and came to be known as the Higgins Experiment, for its innovative use of Total Data Station (TDS) equipment (Black et al. 1998a).
Previous investigations within the 5.3-mile APE were limited in some areas by restricted landowner access, mainly in portions of the roadway east of U.S. 281 (e.g. 41BX947 and 41BX948). However, full access was available for archaeological investigations at 41BX996. Archaeological work west of U.S. 281 was more extensive, including site testing and data recovery in areas near Walker Ranch, including at sites 41BX184, 41BX222, 41BX223, 41BX228, and 41BX1062.

TARL and THC records indicate that 21 linear and areal surveys have been conducted within or adjacent to the APE (Table 4.1). These surveys are related to the proposed roadway construction or expansion as well as adjacent land development, utilities, and park development. Numerous previously conducted surveys are also located within 1 mile of the Wurzbach Parkway Extension Project APE but are not included in Table 4.1.

An inspection of the maps for previous Wurzbach Parkway related archaeological work (Black 1992; Black et al. 1998a; Potter and Black 1995) revealed the currently proposed 2007 roadway configuration is almost identical to the previously investigated alignment. As such, the findings of the previous investigations are directly applicable to this project as potentially significant sites have already been tested for NRHP or SAL eligibility and several significant sites have been data recovered, mitigating any roadway construction impacts (see Chapter 5 for discussion). Thus, while the Wurzbach Parkway APE traverses a portion of the Walker Ranch National Register District, the undertaking does not affect any contributing resources besides those that were previously mitigated.

\section{Previously Recorded Archaeological SITES}

TARL and THC records indicate that 14 archaeological sites have been recorded within or immediately adjacent to the APE (Figure 4.1). These include sites 41BX181, 41BX183, 41BX184, 41BX194, 41BX202, 
41BX203, 41BX209, 41BX222, 41BX223, 41BX228, 41BX947, 41BX948, 41BX949, and 41BX1062 (Table 4.2). In addition, 44 archaeological sites have been encountered within 1 mile of the APE, with most of these recorded during surveys for the Walker Ranch National Historic District. Details about investigations and conclusions for each of the sites in Table 4.2 will be discussed in greater detail in Chapter 5 of this report.

Table 4.1. Previous Archaeological Surveys of the Wurzbach Parkway Between Blanco to Wetmore Roads

\begin{tabular}{|c|c|c|c|c|c|}
\hline $\begin{array}{l}\text { Date of } \\
\text { Survey }\end{array}$ & Agency & Contractor & $\begin{array}{c}\text { Survey } \\
\text { Type }\end{array}$ & Description & Sites Recorded \\
\hline $3 / 1973$ & & $\mathrm{THC}$ & Area & $\begin{array}{l}\text { Located between Blanco Road, Bitters Road, and West } \\
\text { Avenue on the Walker Ranch. It intersects the western portion } \\
\text { of the Wurzbach Parkway APE between West Avenue and } \\
\text { Blanco Road. }\end{array}$ & $\begin{array}{c}\text { 41BX181, 41BX183, } \\
\text { 41BX184, 41BX194, } \\
\text { 41BX202, 41BX203, } \\
\text { 41BX209, 41BX222, } \\
\text { 41BX223, and 41BX228. } \\
\text { Additionally, } 34 \\
\text { archaeological sites were } \\
\text { encountered within } 1 \text { mile of } \\
\text { the project area. }\end{array}$ \\
\hline 1974 & & CAR & Area & $\begin{array}{l}\text { This survey began just north of Bitters Road and ended } 0.5 \\
\text { mile north of the intersection of West Avenue and Rhapsody } \\
\text { Road. It intersects the western portion of the Wurzbach } \\
\text { Parkway APE between West Avenue and Blanco Road. }\end{array}$ & None \\
\hline $7 / 1975$ & & SDHPT & Linear & $\begin{array}{l}\text { This survey follows Wurzbach Road between Fredericksburg } \\
\text { Road and Vance Jackson Road. It is southwest of and does } \\
\text { not intersect the Wurzbach Parkway APE. }\end{array}$ & None \\
\hline 1977 & & CAR & Area & $\begin{array}{l}\text { This survey began } 0.23 \text { mile north of the intersection of U.S. } \\
281 \text { and Nakoma Drive East and terminated } 0.9 \text { mile north of } \\
\text { Panther Springs Creek. It intersects the western portion of the } \\
\text { Wurzbach Parkway APE between West Avenue and U.S. } 281\end{array}$ & None \\
\hline 1977 & & CAR & Linear & $\begin{array}{l}\text { This survey began } 0.7 \text { mile north of the intersection at West } \\
\text { Avenue and Nakoma Drive East and headed northwest to } \\
\text { Loop } 1604 \text { just east of Blanco Road. This survey then turned } \\
\text { around to the eastern side of Huebner Road and continued } \\
\text { southeast until terminating at West Avenue, } 0.9 \text { mile North of } \\
\text { Nakoma Drive East. It intersects the western portion of the } \\
\text { Wurzbach Parkway APE between West Avenue and Blanco } \\
\text { Road. }\end{array}$ & None \\
\hline 1977 & EPA & SDHPT & Area & $\begin{array}{l}\text { Conducted for the SA2WTP, this survey intersects the } \\
\text { Wurzbach Parkway APE from the eastern end of SWCA's } \\
2002 \text { survey to approximately } 0.63 \text { miles east along Starcrest } \\
\text { Road. }\end{array}$ & None \\
\hline $1 / 1979$ & EPA & & Linear & $\begin{array}{l}\text { The investigation consisted of a large tract east of U.S. } 281 \\
\text { and a portion of the current Wurzbach Parkway APE was } \\
\text { surveyed along Salado Creek. }\end{array}$ & None \\
\hline $5 / 1979$ & & SDHPT & Linear & $\begin{array}{l}\text { This survey began on the west side of O'Connor Road just } \\
\text { past Independence Avenue and terminated at the intersection } \\
\text { of Larkdale Drive and O'Connor Road. It is west of and does } \\
\text { not intersect the Wurzbach Parkway APE. }\end{array}$ & None \\
\hline 1979 & SCS & & Area & $\begin{array}{l}\text { This survey was located east of Wetmore Road between } \\
\text { Thousand Oaks Drive and a point north of the proposed } \\
\text { Wurzbach Parkway APE. It does not intersect the Wurzbach } \\
\text { Parkway APE. }\end{array}$ & None \\
\hline 1980 & & CAR & Area & $\begin{array}{l}\text { This survey began } 0.83 \text { mile north of the intersection of } \\
\text { Blanco Road and West Avenue and continued northeast for } \\
\text { approximately } 0.16 \text { mile. It intersects the western portion of } \\
\text { the proposed Wurzbach Parkway APE between West Avenue } \\
\text { and Blanco Road. }\end{array}$ & 41BX338 \\
\hline $10 / 1986$ & FHWA & SDHPT & Linear & $\begin{array}{l}\text { This survey intersects the Wurzbach Parkway APE at } \\
\text { Starcrest Road and was located along Wetmore Road } \\
\text { between East Bitters Road and Thousand Oaks Drive. }\end{array}$ & None \\
\hline 1986 & FHWA & SDHPT & Linear & $\begin{array}{l}\text { This survey intersects the Wurzbach Parkway APE at } \\
\text { Starcrest Road and was located along Wetmore Road } \\
\text { between East Bitters Road and Thousand Oaks Drive. }\end{array}$ & None \\
\hline
\end{tabular}


Table 4.1. Previous Archaeological Surveys of the Wurzbach Parkway Between Blanco to Wetmore Roads, continued

\begin{tabular}{|c|c|c|c|c|c|}
\hline $\begin{array}{l}\text { Date of } \\
\text { Survey }\end{array}$ & Agency & Contractor & $\begin{array}{c}\text { Survey } \\
\text { Type }\end{array}$ & Description & Sites Recorded \\
\hline 1987 & FHWA & SDHPT & Linear & $\begin{array}{l}\text { This survey began at the intersection of U.S. } 281 \text { and Isom } \\
\text { Road and continued along the west side of U.S. } 281 \text { until } \\
\text { terminating at Loop } 1604 \text {. It intersects the western portion of } \\
\text { the Wurzbach Parkway APE at U.S. } 281 \text {. }\end{array}$ & None \\
\hline 1990 & FHWA & & Linear & $\begin{array}{l}\text { This survey started } 0.38 \text { mile north of the intersection at West } \\
\text { Avenue and Nakoma Drive East. It intersects the western } \\
\text { portion of the Wurzbach Parkway APE at West Avenue. It then } \\
\text { headed southeast for } 400 \mathrm{~m} \text { and terminated at West Avenue. }\end{array}$ & None \\
\hline 1990 & FHWA & & Area & $\begin{array}{l}\text { This survey was between West Avenue and Blanco Road, } \\
\text { within the proposed Wurzbach Parkway APE. }\end{array}$ & None \\
\hline 2/1991 & FHWA & SDHPT & Linear & $\begin{array}{l}\text { This survey began } 0.93 \text { mile southwest of the intersection } \\
\text { of IH } 35 \text { and Randolph Road and continued west to the } \\
\text { intersection of Selma and Wurzbach roads. It intersects the } \\
\text { Wurbach Parkway APE from Blanco Road to } 380 \text { m west of } \\
\text { West Avenue. }\end{array}$ & $\begin{array}{c}41 \mathrm{~B} \times 946-950,41 \mathrm{~B} \times 1062 \\
\text { and } 41 \mathrm{~B} \times 1063\end{array}$ \\
\hline 1992 & FHWA & & Linear & $\begin{array}{l}\text { This survey extended along Blanco Road beginning at West } \\
\text { Avenue and ending at Loop 1604. It intersects the western } \\
\text { portion of the Wurzbach Parkway APE at Blanco Road. }\end{array}$ & None \\
\hline 1997 & & CAR & Area & $\begin{array}{l}\text { Located on the Walker Ranch, just north of the intersection } \\
\text { at Nakoma Drive East and West Avenue. It intersected the } \\
\text { western portion of the proposed Wurzbach Parkway APE } \\
\text { between West Avenue and Blanco Road and extended just } \\
\text { south of Panther Springs Creek }\end{array}$ & $41 \mathrm{BX} 1271$ \\
\hline 2002 & FHWA & SWCA & Area & $\begin{array}{l}\text { This survey included the current Wurzbach Parkway APE from } \\
\text { Bitters Road to } 0.44 \text { mile east. }\end{array}$ & None \\
\hline 2003 & & CAR & Area & $\begin{array}{l}\text { Located on the Walker Ranch, just north of the intersection } \\
\text { at Nakoma Drive East and West Avenue. It intersected the } \\
\text { western portion of the proposed Wurzbach Parkway APE } \\
\text { between West Avenue and Blanco Road and extended to the } \\
\text { north and south of Panther Springs Creek. }\end{array}$ & $\begin{array}{c}\text { 41BX1271 Revisit and } \\
\text { Testing }\end{array}$ \\
\hline 2005 & & CAR & Area & $\begin{array}{l}\text { These investigations for the San Antonio Airport were located } \\
\text { along Starcrest Road and intersect the Wurzbach Parkway } \\
\text { APE. }\end{array}$ & None \\
\hline 2006 & SAPARD & CAR & Area & $\begin{array}{l}\text { This survey extended along Salado Creek between Blanco } \\
\text { Road and Huebner Road. It intersects the western portion of } \\
\text { the proposed Wurzbach Parkway APE at Blanco Road. }\end{array}$ & 41BX1656 and 41BX1657 \\
\hline Unknown & FCC & & Area & $\begin{array}{l}\text { Located off Wetmore Road and just past Sentinel Road. It is } \\
\text { south of and does not intersect the Wurzbach Parkway APE. }\end{array}$ & None \\
\hline
\end{tabular}




\begin{tabular}{|c|c|c|c|c|c|c|c|c|c|c|c|c|c|c|}
\hline 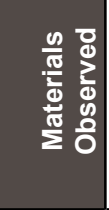 & $\$$ & $\$$ & $\begin{array}{l}\stackrel{\Xi}{\Xi} \\
\stackrel{2}{\Xi}\end{array}$ & 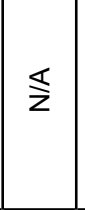 & $\stackrel{\oplus}{\stackrel{\oplus}{\circ}}$ & $\$$ & 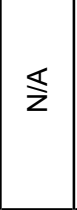 & $\$$ & 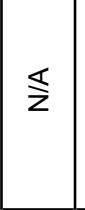 & 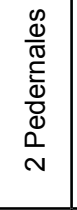 & 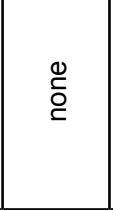 & 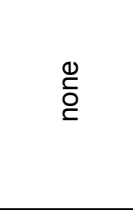 & $\mid$\begin{tabular}{|l}
0 \\
$\stackrel{0}{0}$ \\
$\stackrel{5}{\Xi}$
\end{tabular} & 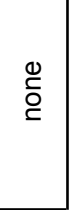 \\
\hline 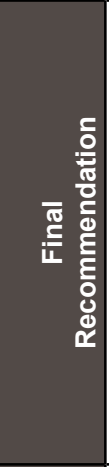 & 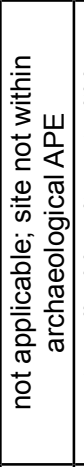 & 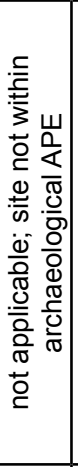 & 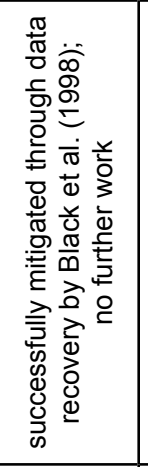 & 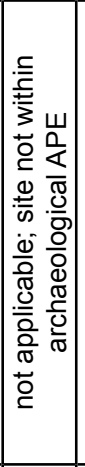 & 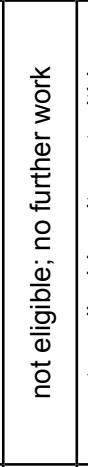 & 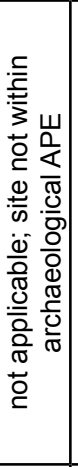 & 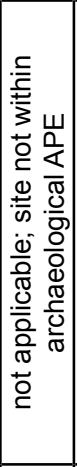 & 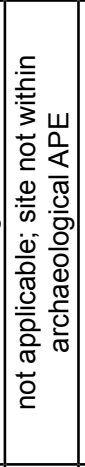 & 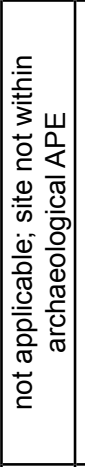 & 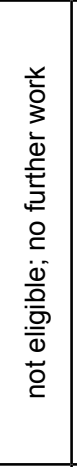 & 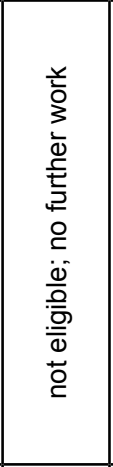 & 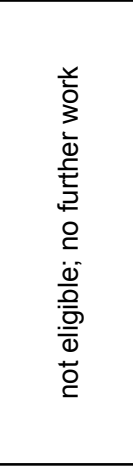 & 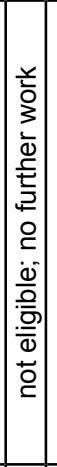 & 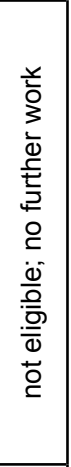 \\
\hline 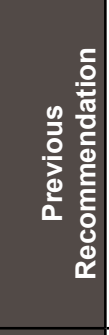 & 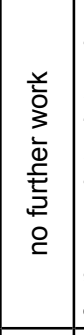 & 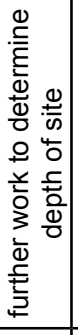 & 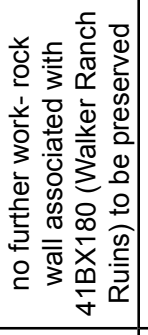 & 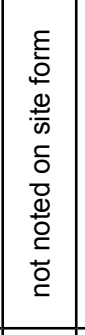 & 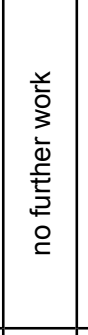 & 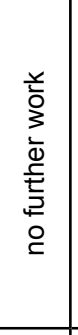 & 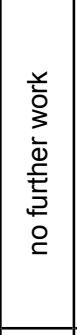 & 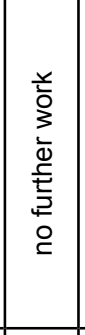 & 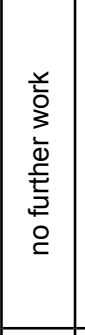 & 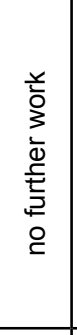 & 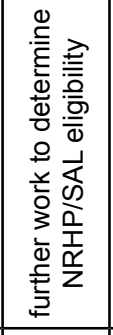 & 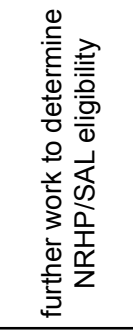 & 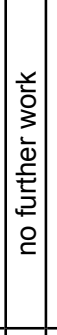 & 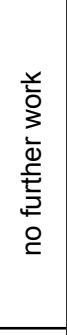 \\
\hline 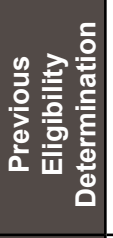 & 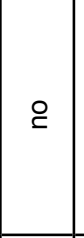 & $\stackrel{\infty}{\infty}$ & $\stackrel{\infty}{\infty}$ & 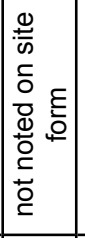 & ঃ & ๑ & ๖ & ๖ & ๕ & 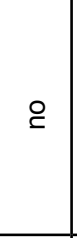 & 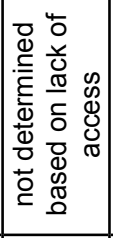 & 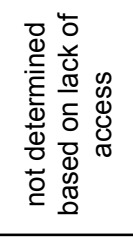 & ○ & 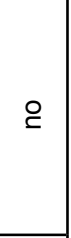 \\
\hline 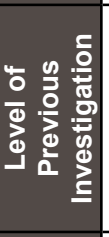 & 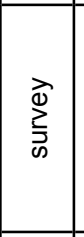 & 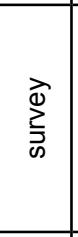 & 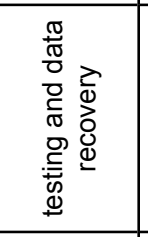 & 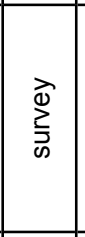 & $\stackrel{\vec{D}}{\vec{\omega}}_{\vec{\omega}}^{\vec{\Delta}}$ & 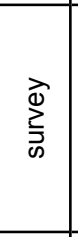 & $\sum_{\omega}^{\vec{d}}$ & 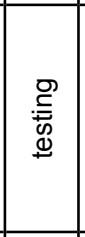 & 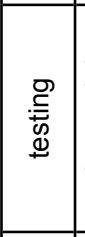 & 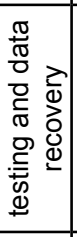 & $\begin{array}{l}\stackrel{\mathscr{D}}{\stackrel{D}{\Phi}} \\
\stackrel{\Phi}{\Phi}\end{array}$ & 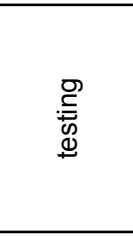 & 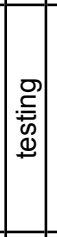 & 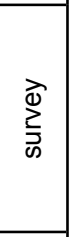 \\
\hline $\begin{array}{l}\frac{0}{2} \\
\frac{0}{2} \\
\frac{9}{2}\end{array}$ & 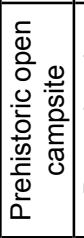 & 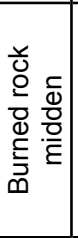 & 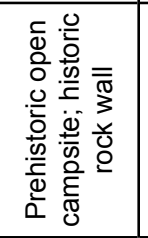 & 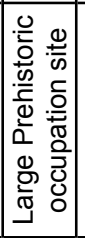 & 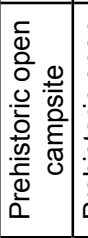 & 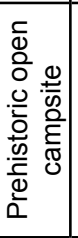 & 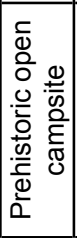 & 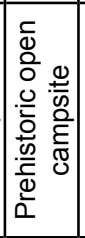 & 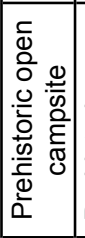 & 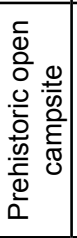 & 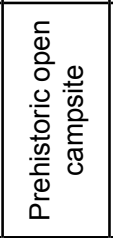 & 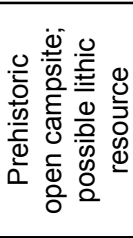 & 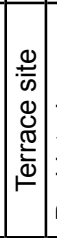 & 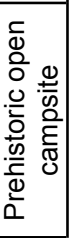 \\
\hline 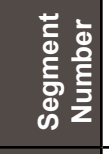 & - & $r$ & $r$ & $r$ & - & - & - & - & - & - & $m$ & $m$ & $\nabla$ & $\sim$ \\
\hline 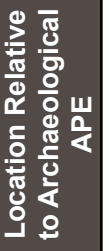 & 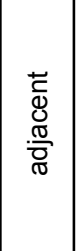 & 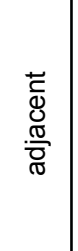 & 竞 & 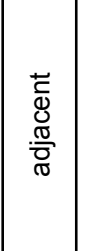 & 挼 & 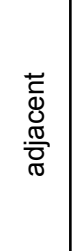 & 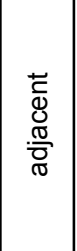 & 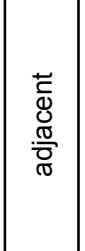 & 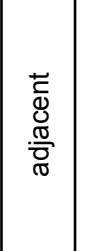 & 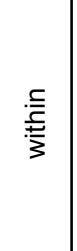 & 禀 & 禀 & $\begin{array}{l}\frac{5}{\bar{E}} \\
\frac{ \pm}{3}\end{array}$ & 喜 \\
\hline 这 & 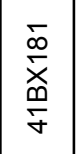 & 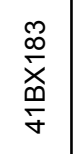 & $\begin{array}{l}\underset{+}{\infty} \\
\underset{x}{x} \\
\stackrel{\infty}{\sigma}\end{array}$ & 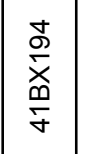 & 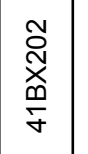 & 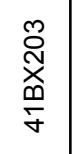 & 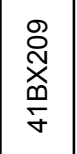 & 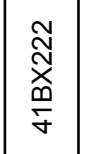 & 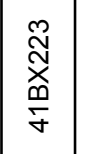 & $\begin{array}{l}\stackrel{\mathscr{N}}{\underset{X}{x}} \\
\stackrel{\infty}{\sim}\end{array}$ & $\begin{array}{l}\text { 市 } \\
\stackrel{x}{x} \\
\stackrel{9}{\dot{y}}\end{array}$ & 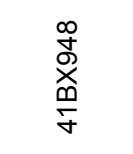 & 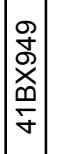 & 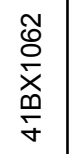 \\
\hline
\end{tabular}




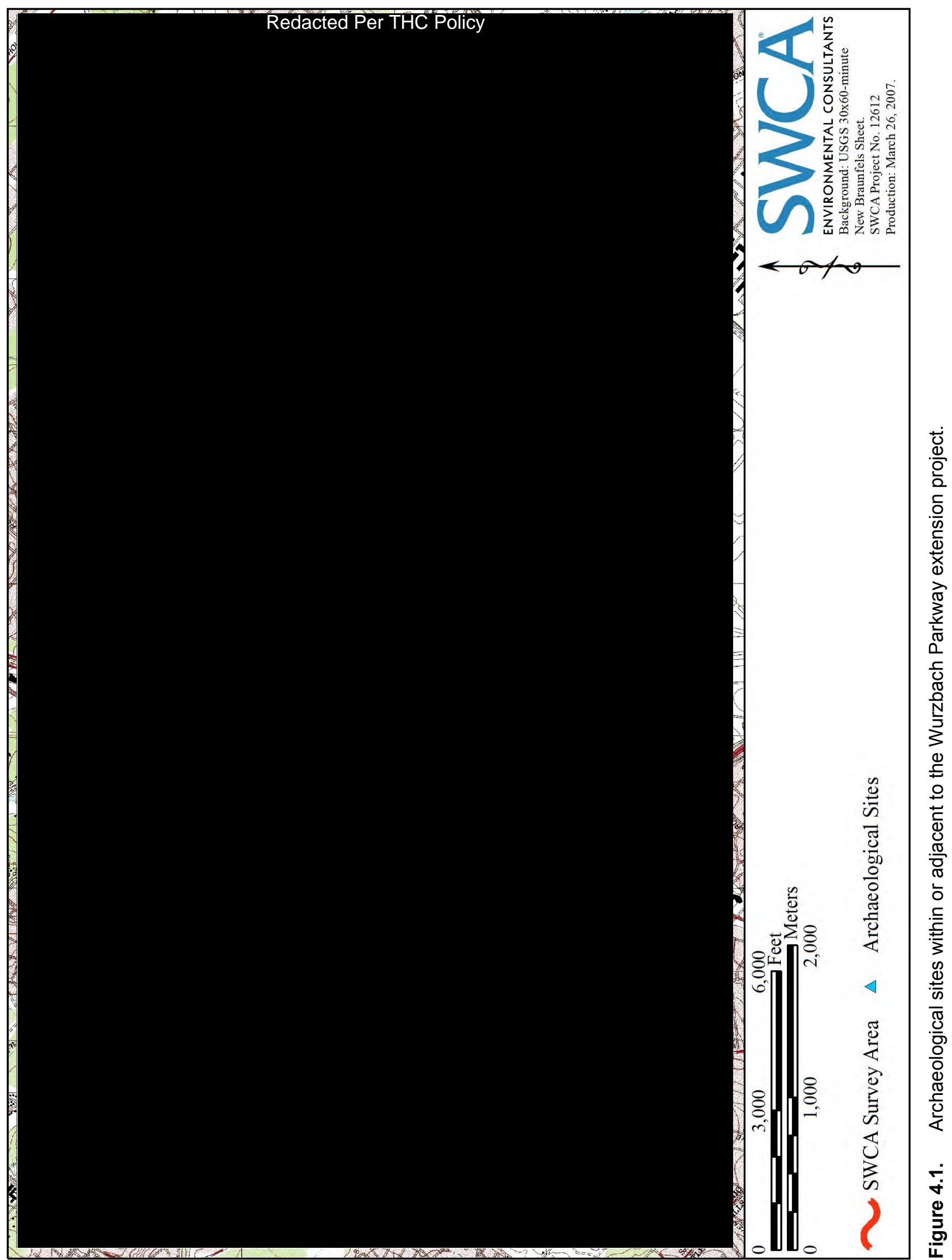





\section{Chapter 5}

\section{Results of Field Investigations}

\section{INTRODUCTION}

SWCA's field investigations of the Wurzbach Parkway Extension Project APE included both reconnaissance and intensive pedestrian survey, shovel testing at sites $41 \mathrm{BX} 228$ and 41BX948, and backhoe trenching at 41BX947 and of selected areas along the Salado Creek floodplain between Coker West Loop and Jones Maltsberger Road. Right of entry was denied at two properties, including the Coker United Methodist Church, which precluded a revisit to 41BX1062, located within the APE (Figure 5.1).

Of the 14 previously recorded sites within or immediately adjacent to the APE (see Table 4.2), seven were determined not to extend into the APE (41BX181, 41BX183, 41BX194, 41BX203, 41BX209, 41BX222, and 41BX223). Two of the seven sites within the APE had been successfully mitigated through prior data recovery efforts (41BX184 and 41BX228), while landforms associated with site 41BX202 were found to have been completely destroyed. Site 41BX949 was investigated at a reconnaissance level, based on the results of prior work.

To facilitate description, the APE is divided into four segments (west to east) that correspond to engineering segments as follows:

Segment 1: Blanco Road to West Avenue (CSJ 0915-12-224);

Segment 2: West Avenue to U.S. 281 (CSJ 800015-008);

Segment 3: U.S. 281 to Jones Maltsberger Road (CSJ 8000-15-011);

Segment 4: Jones Maltsberger Road to Wetmore Road (CSJ 8000-15-012).

Seven locales (1-5, A, and B) for permanent and temporary easements were subsequently added to the design and surveyed by TxDOT archaeologist Al McGraw in 2010. Locale 1 is near the western end of Segment 1, Locales 2 and 3 are within Segment 3, and Locales 4, 5, A, and B are within Segment 4. Maps presented in this chapter for each of the segments include labeled representations of these locations. A summary of the findings from the TxDOT survey are included in this chapter. The entire TxDOT interim report for the survey is contained in Appendix A.

\section{Segment 1}

\section{Blanco Road to West Avenue}

Background reviews revealed this entire segment had been previously surveyed as part of the old Wurzbach Parkway archaeological investigations in the 1980s and 1990s (Black 1992; Black et al. 1998a; Potter and Black 1995). Ten archaeological sites have been recorded within or directly adjacent to this segment.

A 100 percent pedestrian survey was accomplished in this section of the APE by three archaeologists. The APE follows the existing roadway, Vista del Norte, for about $300 \mathrm{~m}$ (Figures 5.2 and 5.3) from Blanco Road west to the San Antonio River Authority (SARA) property associated with the flood control dam at the confluence of Panther Springs and Salado creeks. A 0.053 -acre permanent easement was surveyed by TxDOT north of Vista del Norte at Salado Creek. No cultural materials were encountered within the easement.

The APE then continues across a wooded slope for about $450 \mathrm{~m}$ before intersecting Vista del Norte as the APE begins to cross SARA property and a portion of the Walker Ranch National Register District. Sites 41BX202, 41BX203, and 41BX209 were previously recorded in this section of the segment.

After crossing Vista del Norte, the APE traverses SARA property for about $1,400 \mathrm{~m}$ (including a portion of the Walker Ranch National Register District for about $760 \mathrm{~m}$ ) until it intersects West Avenue. Between Vista del Norte and the flood control dam, the landscape has been heavily modified (Figures 5.4 and 5.5). Conversely, between the dam and West Avenue the terrain is wooded and exhibits smaller-scale impacts such as berms, trails, and trash dumping. Between the dam and the two-track road on SARA property are large oak trees; however, mesquite trees dominate the area 


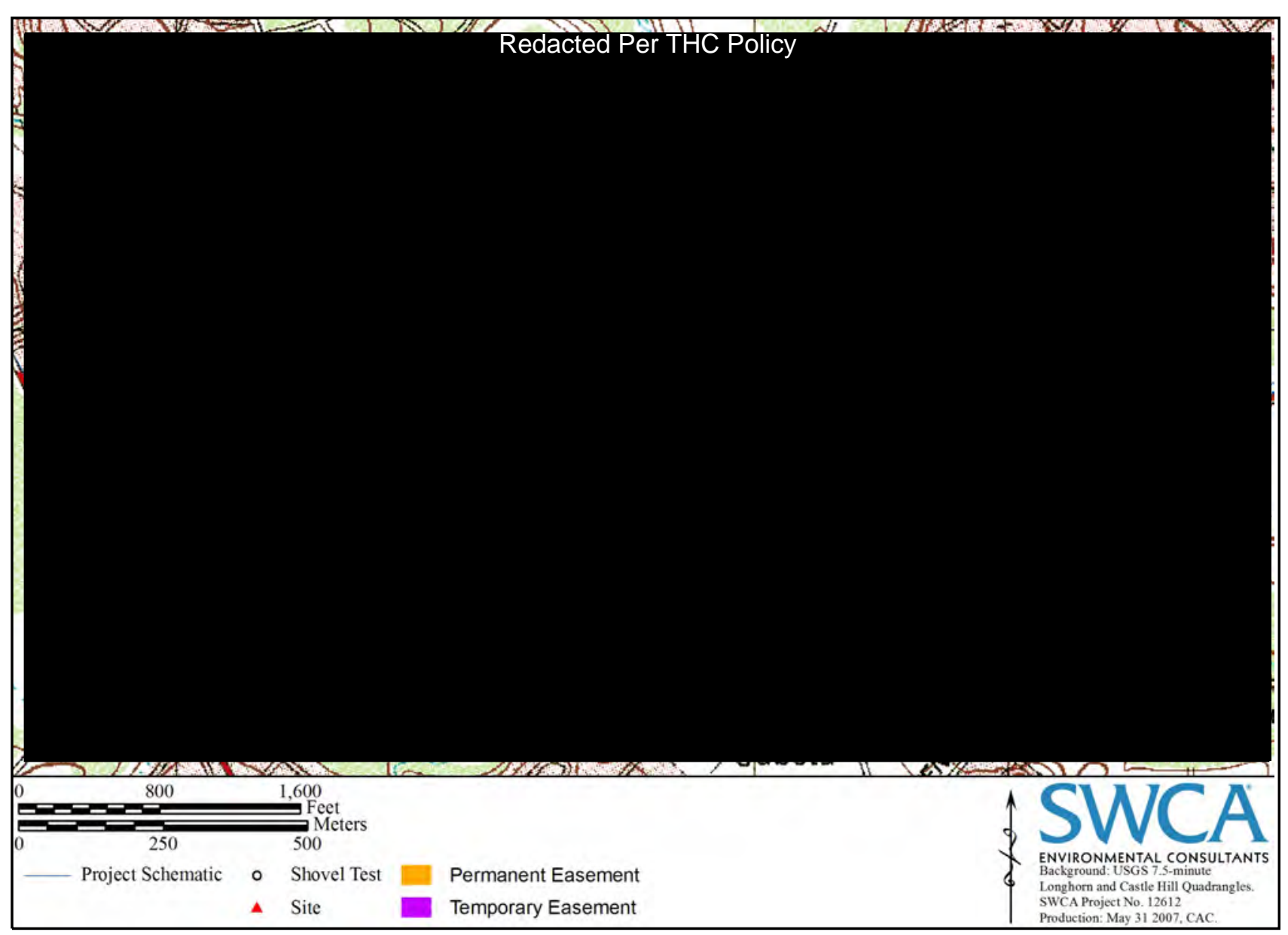

Figure 5.1. Segment 1, Wurzbach Parkway from Blanco Road to West Avenue.

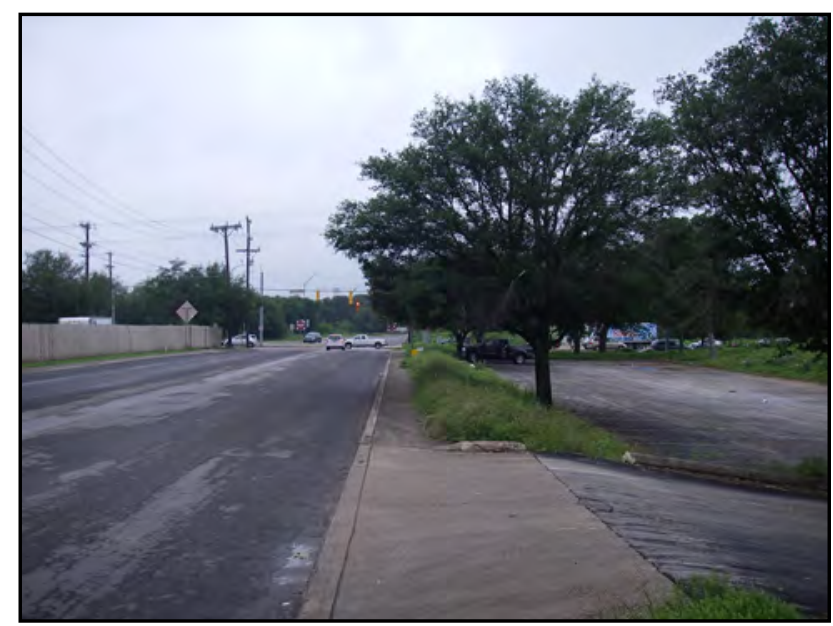

Figure 5.2. Proposed Wurzbach Parkway rightof-way at Vista del Norte and Blanco Road facing west.

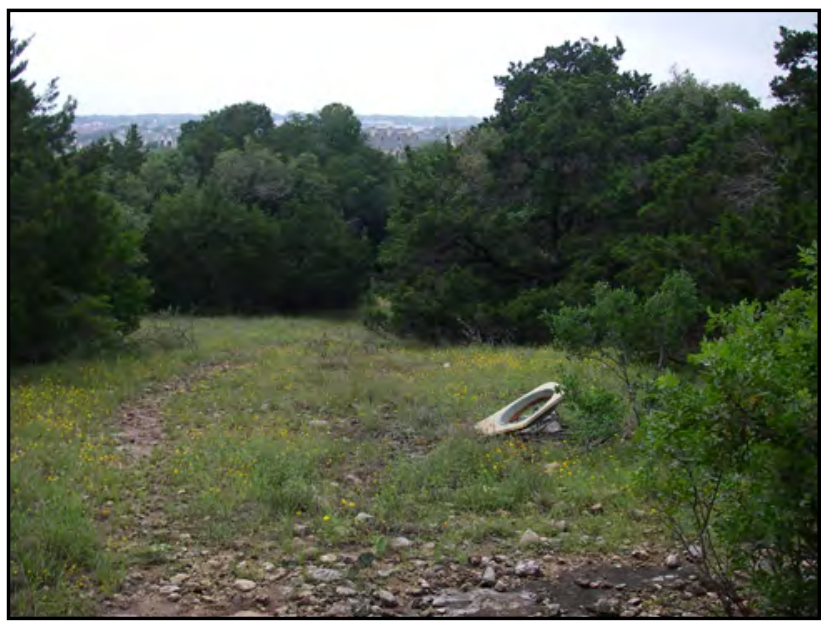

Figure 5.3. Proposed Wurzbach Parkway rightof-way between Blanco Road and Vista del Norte near site 41BX209 facing south and illustrating trash, exposed bedrock, and rocky soils. 


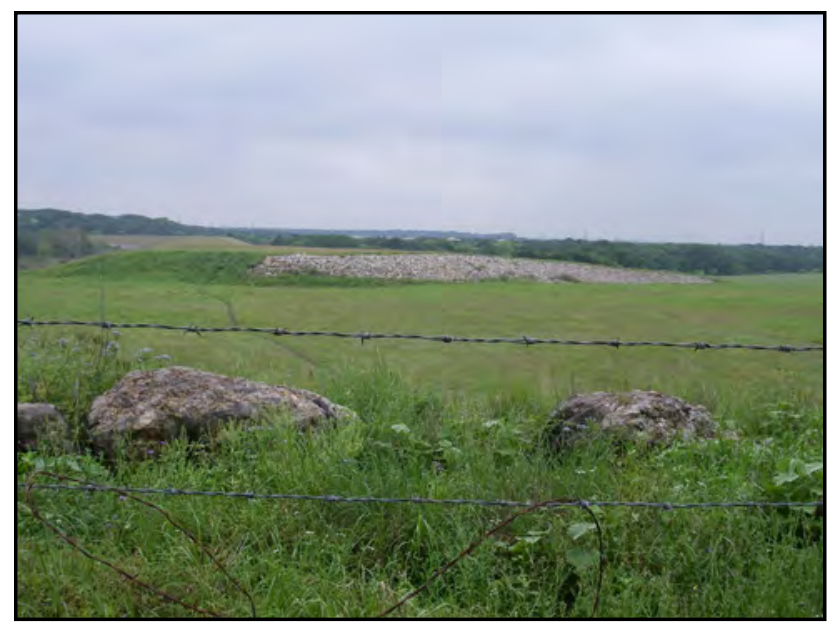

Figure 5.4. Proposed Wurzbach Parkway rightof-way east of Vista del Norte near sites 41BX181 and 41BX183 facing east and illustrating major land modifications associated with the flood control dam construction.

between the two-track road and West Avenue, suggesting this area was previously disturbed by the clearing of vegetation. Sites 41BX181, 41BX183, 41BX184, 41BX194, 41BX222, 41BX223, and 41BX228 were previously recorded in this section of APE.

\section{SITE $41 B X 181$}

Site 41BX181 was originally recorded in 1974 by William Hudson, Jr., based on the presence of numerous large flakes scattered throughout the site, numerous flint cores lying on the surface, and the presence of retouching flakes, unifacial scrapers, bifacial scrappers, and knives (TARL files). No diagnostic projectile points were recovered from the site and no features were identified.

The site was recorded on a flat river terrace that backed up to a hill. Considerable disturbances were evident, including road and fence construction, cattle grazing, and plowing. A portion of 41BX181 was destroyed to create the base for a fence line, which bisects the site. Hudson estimated the site size as 1,000 square $\mathrm{m}$ and its depth ranged from 6-12 feet. His determinations were based on the limits of a surficial lithic scatter as his investigations did not include subsurface excavations. Hudson did not recommend further archaeological work at 41BX181; it is not listed on the NRHP as a contributing member of the Walker Ranch National Historic District.
At present, site 41BX181 is surrounded by residential development. The site was either destroyed by residential development or by the construction of a flood control dam in the late 1980s at the confluence of Panther Springs and Salado creeks, both of which involved extensive alteration of the natural landscape (see Figures 5.4 and 5.5). The site is adjacent to the proposed Wurzbach Parkway Extension Project ROW, but does not extend into it. No cultural materials associated with 41BX181 were detected within the APE during SWCA's current survey.

\section{SITE $41 B X 183$}

Site 41BX183 was also recorded in 1974 by Hudson (TARL files). Described as a small burned rock midden, 41BX183 is located on a small level spot on the slope of a hill above site 41BX181. A two-track road ran through the site and exposed many different materials, including scattered lithic debitage, unifacial and bifacial scrapers, non-diagnostic fragments of several projectile points, and one Perdiz arrow point. No features were identified at 41BX183, where a thin layer of top soil sat on bedrock. The site appeared partially deflated and Hudson interpreted the Perdiz point as being intrusive to the midden.

Hudson estimated the site size as 70 square $m$ and its depth at $10 \mathrm{~cm}$. His determinations were based on

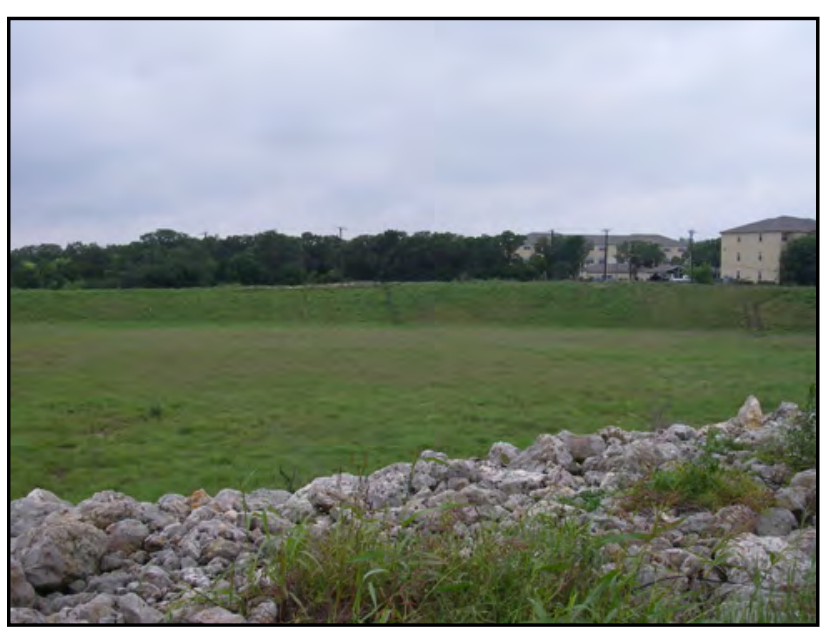

Figure 5.5. Proposed Wurzbach Parkway right-of-way west of Vista del Norte near site 41BX184 facing west and illustrating major land modifications associated with the flood control dam construction. Rock pile in the foreground is the same one seen in the background of Figure 5.4. 
the limits of a surficial lithic scatter as his investigations did not include subsurface excavations. Hudson recommended further archaeological work at the site to determine its actual depth; however, it is not listed on the NRHP as a contributing member of the Walker Ranch National Historic District.

At present, site 41BX183 is surrounded by residential development. The site was destroyed by the construction of a flood control dam in the late 1980s at the confluence of Panther Springs and Salado creeks, which involved extensive alteration of the natural landscape (see Figures 5.4 and 5.5). No cultural materials associated with 41BX183 were detected within the APE during SWCA's current survey.

\section{SITE $41 B \times 184$}

Site 41BX184 was also recorded in 1973 by Hudson (TARL files). Described as a small open site with scattered lithic debris on the west bank of Panther Creek, it was adjacent to site 41BX197. Site 41BX184 extended back from the creek about 30-40 feet and was partially deflated in places. A remnant of a rock wall, associated with 41BX180, formed a corner of the site. Hudson noted that parts of the northern half of the site had been under cultivation at times, with the plow penetrating to a depth of 6 inches.

Hudson estimated the site size as $50-75$ square $m$ with an unknown depth. His determinations were based on the limits of a surficial lithic scatter as his investigations did not include subsurface excavations. Along with the numerous flint flakes scattered about the surface were unifacial scrapers, a barbed projectile point fragment, small retouch flakes, and burned rocks. Hudson did not recommend further archaeological work at 41BX184; however, the site was listed on the NRHP as a contributing member of the Walker Ranch National Historic District.

TARL archaeologists investigated the site in 1992 and 1993 as part of the Wurzbach Parkway Project (Black et al. 1998a). During the intervening years since the site's discovery, a portion of 41BX184 had been destroyed by the construction of a flood control dam in the late 1980s at the confluence of Panther Springs and Salado creeks. The 1992 testing investigations documented intact Late Archaic deposits, including a buried burned rock midden and a hearth field. Data recovery inves- tigations were accomplished the following year and came to be known as the Higgins Experiment, for the innovative use of TDS piece-plotting. The burned rock midden contained intact remains of large ovens, which were the heated elements of basin-shaped roasting pits, probably used for processing plant foods. The hearth field contained a large range of cooking features of varying sizes, representing a wide range of behaviors.

At present, site 41BX184 is surrounded by the flood control dam (Figure 5.6). Based on the observance of numerous minor alterations to the landscape, the site has apparently continued to be a target of looters since the data recovery investigations were completed in the 1990s. For example, Datum 5 from those investigations, a rebar rod encased in concrete, was relocated during SWCA's current survey between two looter's pits. Numerous flakes were visible on the surface; however, no diagnostic artifacts associated with 41BX184 were detected within the Wurzbach Parkway Extension Project APE.

Overall, Black et al. (1998a) investigations covered the current proposed Wurzbach Parkway Extension Project APE, mitigating potential roadway construction impacts with their extensive excavations. Therefore, no further work is recommended.

\section{SITE $41 B \times 194$}

Site 41BX194 was originally recorded in 1974 by Thomas R. Hester across Salado Creek from a Fort Sam Houston golf course that was being constructed

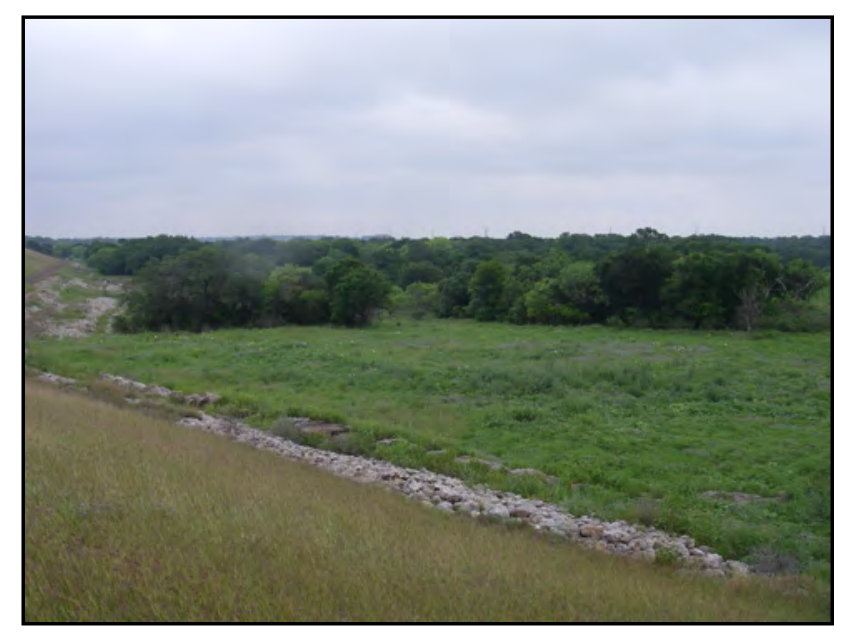

Figure 5.6. Proposed Wurzbach Parkway rightof-way at site 41BX184 taken from the top of the flood control dam, facing east. 
(TARL files). The site had been heavily damaged by the military's removing of fill for use in the golf course. Site 41BX194 extended along a low terrace of Salado Creek, where a bulldozer had exposed two localities; one with a hearth and another with hearth midden deposits, including flakes. A private collection from the site contained diagnostic artifacts from the Late Prehistoric (Scallorn, Perdiz, and 12 bone-tempered potsherds), and the Middle and Late Archaic (Abasolo, Tortugas, and stemmed biface forms). Hester did not estimate the site size or its depth; however, he noted an extensive lithic scatter of debitage and burned rock. His investigations did not include subsurface excavations. Hester did not note the site's eligibility for inclusion to the NRHP or for designation as an SAL; nor did he offer a recommendation of the need for further archaeological work at the site.

At present, site 41BX194 is presumably surrounded by the golf course and residential de velopment (the site was not re-located during the SWCA survey, which was restricted to the proposed Wurzbach Parkway Extension Project ROW). The site was described by Hester as across the creek from the golf course; therefore, portions of the site may have been disturbed by the construction of a flood control dam in the late 1980s at the confluence of Panther Springs and Salado creeks. No cultural materials associated with 41BX194 were detected within the APE during SWCA's current survey. The site is adjacent to the pro-posed Wurzbach Parkway Extension Project ROW, but does not extend into it. Undoubtedly, the extent of disturbance from golf course and dam construction would have had a negative impact on the site's eligibility for listing on the NRHP or for SAL designation.

\section{SITE $41 B X 202$}

Site 41BX202 was recorded in 1973 by Hudson during the initial THC survey of Walker Ranch (TARL files). Described as a small open site on the east bank of Salado Creek, site 41BX202 was partially in a large open field with two-track roads crossing it in several places. A small portion of the site extended into an undisturbed area of trees along the creek.

The site had been impacted by heavy erosion along the roads and by cattle. The field had been cleared and plowed up to depth of $15 \mathrm{~cm}$ during the twentieth century. Relatively small amounts of lithic material were evident on the surface. Burned rock, debitage and several side and end scrapers from primary and secondary flakes were among the cultural material observed. No diagnostic projectile points were recovered from the site and no features were identified.

Hudson estimated the site size as $50-75$ square $m$ and its depth ranged from $6-10 \mathrm{~cm}$. His determinations were based on the limits of a surficial lithic scatter as his investigations did not include subsurface excavations. Hudson did not recommend further archaeological work at 41BX202.

At present, the site is surrounded by roads and residential development. The portion of the site within the ROW has been previously disturbed by road and bridge construction, leaving no intact landforms associated with the site. No cultural materials associated with 41BX202 were detected within the APE during SWCA's current survey. SWCA's assessment concurs with the previous findings of non-significance for this site. Therefore, the site is not considered eligible for inclusion to the NRHP or for designation as an SAL and no further work is recommended.

\section{SITE $41 B X 203$}

Site 41BX203 was also recorded in 1973 by Hudson (TARL files). Like the previous site, 41BX203 is described as a small open site on the east bank of Salado Creek with a two-track road bisecting it. The site was partially in a large open field and extended into an undisturbed area of trees along the creek. The site had been impacted by heavy erosion along the road and by cattle. The field had been cleared and plowed up to depth of $15 \mathrm{~cm}$ during the twentieth century. Relatively small amounts of lithic material were evident on the surface. Primary and secondary flake tools comprised the cultural material observed. No tertiary flakes, bifaces, or diagnostic projectile points were recovered from the site and no features were identified.

Hudson estimated the site size as 50 square m. His determinations were based on the limits of a surficial lithic scatter as his investigations did not include subsurface excavations. Hudson did not recommend further archaeological work at the site.

At present, site 41BX203 has been destroyed by residential development along Vista del Norte. The site is 
adjacent to the proposed Wurzbach Parkway Extension Project ROW, but does not extend into it. No cultural materials associated with 41BX203 were detected within the APE during SWCA's current survey.

\section{SITE $41 B \times 209$}

Site 41BX209 was also recorded in 1973 by Hudson (TARL files). Like the two previous sites, 41BX209 is described as a small open alluvial terrace site on the east bank of Salado Creek with two-track roads and two fence lines crossing it. The site was in a large open field and had been heavily impacted by heavy erosion along the roads and by cattle. The field had been cleared and plowed up to a depth of $15 \mathrm{~cm}$ during the twentieth century. Relatively small amounts of lithic material were evident on the surface. Primary, secondary, and tertiary flakes comprised the cultural material observed. No diagnostic projectile points were recovered from the site and no features were identified.

Hudson estimated the site size as 75 square m. His determinations were based on the limits of a surficial lithic scatter as his investigations did not include subsurface excavations. Hudson did not recommend further archaeological work at the site.

At present, site 41BX209 is surrounded by residential development and is likely destroyed (see Figure 5.3). The site is adjacent to the proposed Wurzbach Parkway Extension Project ROW, but does not extend into it. No cultural materials associated with 41BX209 were detected within the APE during SWCA's current survey.

\section{SITE $41 B X 222$}

Site 41BX222 was also recorded in 1973 by Hudson (TARL files). It is described as an al-luvial terrace site on the east bank of Panther Springs Creek near its confluence with Salado Creek. Unlike the preceding sites, 41BX222 was in a heavily wooded area and was relatively undisturbed. Randomly scattered burned rock and lithic material were evident on the surface. Primary and secondary flakes, some worked into side or end scrapers, and thick crude bifaces comprised the cultural material observed. No diagnostic projectile points were recovered from the site and no features were identified.
Hudson estimated the site size as 100-1,500 square m. His determinations were based on the limits of a surficial lithic scatter as his investigations did not include subsurface excavations. Hudson recommended further archaeological work at the site and it was listed on the NRHP as a contributing member of the Walker Ranch National Historic District.

The next mention of 41BX222 in the literature is by Thomas R. Hester (1974). Although he did not excavate at the site, he proposed that $41 \mathrm{BX} 222$ represented a continuation of nearby 41BX228, the Panther Springs site, through a densely vegetated area.

Testing excavations in 1993 confirmed Hester's suspicions (Potter and Black 1995). Seven machineexcavated trenches were placed within the boundaries of 41BX222 and revealed no break in occupational debris between the two sites. Substantial disturbance from previous looting was documented within many of the trenches along with moderate densities of burned rock and lithic debitage. No diagnostic projectile points were recovered from the site and no features were identified. Hand excavations were not attempted based on the degree of previous disturbance observed and the sparse nature of the cultural deposits.

Potter and Black (1995) recommended no further work at the site. They also recommended that 41BX222 was no longer worthy of being listed as a contributing member of the Walker Ranch National Historic District.

At present, site 41BX222 is surrounded by wooded areas and residential and dam development. The site is adjacent to the proposed Wurzbach Parkway Extension Project ROW, but does not extend into it. No cultural materials associated with 41BX222 were detected within the APE during SWCA's current survey. SWCA's assessment concurs with the previous findings of non-significance for this site. Therefore, the site is not considered eligible for inclusion to the NRHP or for designation as an SAL and no further work is recommended.

\section{SITE $41 B X 223$}

Site 41BX223 was also recorded in 1973 by Hudson (TARL files). It is described as an alluvial terrace site on the east bank of Panther Springs Creek near its confluence with Salado Creek. Site 41BX223 was in 
a heavily wooded area and was relatively undisturbed, although a two-track road to a dear blind bisected the site. Artifacts collected from this road included bifaces, both large thick ones and small well-chipped ones, and numerous side and end scrapers fashioned from primary, secondary, and tertiary flakes. No diagnostic projectile points were recovered from the site and no features were identified.

Hudson estimated the site size as 800 square $m$ and its depth at $6-15 \mathrm{~cm}$. His determinations were based on the limits of a surficial lithic scatter as his investigations did not include subsurface excavations. Hudson recommended further archaeological work at the site to determine its actual depth and it was listed on the NRHP as a contributing member of the Walker Ranch National Historic District.

Testing excavations in 1993 revealed that site 41BX223 lacked sufficient preservation and structural integrity necessary for the site to be eligible for listing in the NRHP or for designation as an SAL (Potter and Black 1995). Three machine-excavated trenches were placed within the boundaries of 41BX223. No diagnostic projectile points were recovered from the site and no features were identified. Hand excavations were not attempted based on the sparse nature of the cultural deposits. Potter and Black (1995) recommended no further work at the site. They also recommended that 41BX223 was no longer worthy of being listed as a contributing member of the Walker Ranch National Historic District.

At present, site 41BX223 is surrounded by wooded areas, the dam, and residential development. The site is adjacent to the proposed Wurzbach Parkway Extension Project ROW, but does not extend into it. No cultural materials associated with 41BX223 were detected within the APE during SWCA's current survey. SWCA's assessment concurs with the previous findings of non-significance for this site. Therefore, the site is not considered eligible for inclusion to the NRHP or for designation as an SAL and no further work is recommended.

\section{SITE $41 B X 228$}

Site 41BX228 was recorded in 1973 by Hudson and Warren Lynn (TARL files), described as a burned rock midden located on the edge of the steep eastern bank of
Panther Springs Creek near its confluence with Salado Creek. Site 41BX228 was in a wooded area and relatively undisturbed. One 20 -cm level of a 1 square $\mathrm{m}$ test unit yielded numerous artifacts including bison bone and 12 diagnostic projectile points from the Archaic and Late Prehistoric periods.

Hudson and Lynn estimated the site size as 100-200 square $\mathrm{m}$ and its depth at more than $50 \mathrm{~cm}$. His determinations were based on the limits of a surficial lithic scatter and the excavation of a single test unit. Hudson recommended further archaeological work at the site to determine its actual depth.

In 1974 two more test pits were excavated at site 41BX228 (Kelly 1974). Again, abundant artifacts were encountered from $0-60 \mathrm{~cm}$ below surface, including 40 diagnostic projectile points. T. C. Kelly enlarged the site's boundary based on the extent of the surficial lithic scatter to 36,000 square $m$. As a result of the 1973 and 1974 investigations, 41BX228 was listed on the NRHP as a contributing member of the Walker Ranch National Historic District.

In 1979 CAR archaeologists initiated data recovery investigations at $41 \mathrm{BX} 228$ prior to the construction of a flood control dam in the 1980s (Black and McGraw 1985). Extensive mechanical trenching revealed at least four burned rock middens. The beginning of three of these features was dated to about 4,500 B.P. Site boundaries were reevaluated and adjusted down to 3,200 square $\mathrm{m}$ based on the site's subsurface extent. Habitation at 41BX228 produced overlapping occupations that were not separated by sterile layers of deposition and were characterized as semistratified (Black and McGraw 1985:272). In general, older artifact styles tended to be deeper than younger ones, but there were many exceptions. Despite these difficulties, seven cultural components were identified at 41BX228 spanning approximately 5,500 years.

Archaeologists from TARL investigated 41BX228 in 1992, targeting intact Zone II deposits as part of the proposed Wurzbach Parkway project for TxDOT (Potter and Black 1995). This stratum had been referred to as a transition zone (Black and McGraw 1985) between the overlying organically-rich soil (Zone I) and gravels below. Most of the earliest occupation materials from 41BX228 occurred within the transition zone. During the intervening years, looters had completely ravaged 


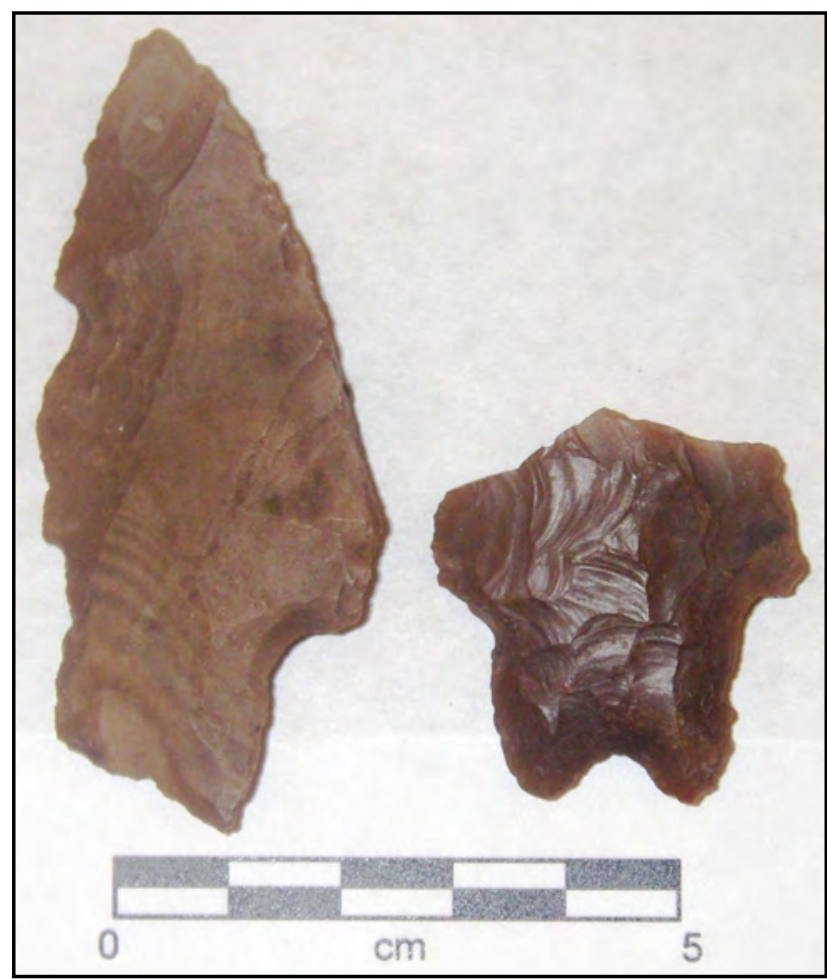

Figure 5.7. Fragments of two Pedernales projectile points recovered from the surface of site 41BX228.

the Zone I deposits that had been the target of the 1979 investigations. The TARL crew used a Gradall to remove the disturbed overburden. Three trenches, 15 shovel tests, and 17 test units were then excavated.

TARL excavations demonstrated that the once-extensive site had been reduced by looting to a few remnant deposits (Potter and Black 1995). These remnants represented secondary cultural deposits; thus, no further work was recommended for 41BX228. Potter and Black (1995) also recommended that the site was no longer worthy of being listed as a contributing member of the Walker Ranch National Historic District.

At present, site $41 \mathrm{BX} 228$ is surrounded by the dam and residential development. Hiking and bicycling trails associated with the adjacent Walker Ranch Park traverse the site. Two Pedernales projectile points were collected from the surface of 41BX228 within the APE during SWCA's current survey (Figure 5.7). Shovel tests were excavated near the projectile points to determine whether buried intact archaeological resources were present (Table 5.1, Figure 5.8). No cultural materials were encountered in any shovel tests excavated by SWCA at site 41BX228. Overall, investigations by Black and McGraw (1985) and Potter and Black (1995) covered the current proposed Wurzbach Parkway Extension Project APE, mitigating potential roadway construction impacts with their extensive excavations. As previously stated, Potter and Black (1995) recommended that the site was no longer worthy of being listed as a contributing member of the Walker Ranch National Historic District. SWCA's assessment concurs with the previous findings for this site. Therefore, the site is no longer considered eligible for inclusion to the NRHP or for designation as an SAL and no further work is recommended.

\section{Segment 2 West Avenue to U.S. 281}

Background reviews revealed this entire segment had been previously surveyed as part of several surveys, including the old Wurzbach Parkway archaeological investigations (Black 1992; Black et al. 1998a; Potter and Black 1995). Only one archaeological site was recorded within this segment.

A 100 percent pedestrian survey of all properties for which right of entry access was granted was accomplished in this section of the APE by four archaeologists. This segment includes the Oceans Windows, Inc., property in the southwest quadrant of the intersection of North Loop Road and U.S. 281, where a cloverleafshaped exit/entrance ramp would be located.

The APE east of West Avenue for about $450 \mathrm{~m}$ is an area that is being used as a landfill and quarry (Figure 5.9). Temporary construction easements are located to the north and south of the ROW on private land. Right of entry for survey was not granted on several large sections by several landowners along this segment of the APE, including Interpark Associated, LTD, and Coker United Methodist Church. The APE at the Coker Church property includes utility buildings and about a 100 -m-long strip of temporary construction easement. The easement would be located on existing church parking lots.

The previously recorded archaeological site, 41BX1062, is within the central portion of this segment of the APE. The original site boundaries were confined to an elevated ridge of a natural terrace, which is entirely on Coker United Methodist Church property. Although a revisit to the site was precluded by a lack of right of entry, four shovel tests were excavated on 
Table 5.1. Shovel Test Data

\begin{tabular}{|c|c|c|c|c|c|c|c|}
\hline $\begin{array}{l}\text { Shovel } \\
\text { Test \# }\end{array}$ & Site & $\begin{array}{l}\text { Depth } \\
\text { (cmbs) }\end{array}$ & Munsell & Soil Color & $\begin{array}{l}\text { Soil Texture } \\
\text { Description }\end{array}$ & Inclusions & Comments \\
\hline \multirow{2}{*}{ D1 } & \multirow{2}{*}{ 41BX228 } & $0-20$ & 7.5YR3/1 & $\begin{array}{c}\text { very dark } \\
\text { gray }\end{array}$ & silty clay loam & rootlets & $\begin{array}{l}\text { wooded channel bar in historic district for } \\
\text { Walker Ranch; no cultural materials }\end{array}$ \\
\hline & & $20-28$ & 7.5YR3/3 & dark brown & $\begin{array}{c}\text { sub-rounded } \\
\text { limestone gravels }\end{array}$ & $\begin{array}{l}\text { abundant } \\
\text { gravels }\end{array}$ & $\begin{array}{l}\text { wooded channel bar in historic district for } \\
\text { Walker Ranch; no cultural materials }\end{array}$ \\
\hline \multirow{2}{*}{ D2 } & \multirow{2}{*}{ 41BX228 } & $0-28$ & 7.5YR2.5/1 & black & silty clay loam & $\begin{array}{c}\text { roots and } \\
\text { rootlets }\end{array}$ & $\begin{array}{l}\text { wooded channel bar in historic district for } \\
\text { Walker Ranch; no cultural materials }\end{array}$ \\
\hline & & $28-60$ & 7.5YR3/4 & dark brown & loamy clay & $\begin{array}{l}\text { roots and } \\
\text { rootlets }\end{array}$ & $\begin{array}{l}\text { wooded channel bar in historic district for } \\
\text { Walker Ranch; no cultural materials. }\end{array}$ \\
\hline D3 & 41BX948 & $0-20$ & 7.5YR2.5/1 & black & silty loam & $\begin{array}{l}\text { roots and } \\
\text { rootlets }\end{array}$ & $\begin{array}{l}\text { wooded terrace at site } 41 \mathrm{BX} 948 ; \text { no cultural } \\
\text { materials; basal gravels at } 20 \mathrm{cmbs}\end{array}$ \\
\hline D4 & 41BX948 & $0-20$ & 7.5YR2.5/1 & black & silty loam & rootlets & $\begin{array}{c}\text { wooded terrace at site } 41 \mathrm{BX} 948 ; \text { no cultural } \\
\text { materials; basal gravels at } 20 \mathrm{cmbs}\end{array}$ \\
\hline \multirow{2}{*}{ D5 } & \multirow{2}{*}{ 41BX948 } & $0-35$ & 10YR3/1 & $\begin{array}{l}\text { very dark } \\
\text { gray }\end{array}$ & silty loam & rootlets & $\begin{array}{l}\text { wooded terrace at site } 41 \mathrm{BX} 948 ; \text { no cultural } \\
\text { materials }\end{array}$ \\
\hline & & $35-40$ & 10YR3/2 & $\begin{array}{c}\text { very dary } \\
\text { grayish brown }\end{array}$ & silty loam & rootlets & $\begin{array}{c}\text { no cultural materials; basal gravels at } 40 \\
\text { cmbs }\end{array}$ \\
\hline \multirow{2}{*}{ MJ1 } & \multirow{2}{*}{$41 \mathrm{BX} 228$} & $0-40$ & 10YR2/1 & black & clay loam & $\begin{array}{l}\text { roots and } \\
\text { rootlets }\end{array}$ & $\begin{array}{c}\text { in historic district for Walker Ranch; no } \\
\text { cultural materials }\end{array}$ \\
\hline & & $40-45$ & 10YR3/3 & dark brown & clay loam & $\begin{array}{l}\text { roots and } \\
\text { gravels }\end{array}$ & $\begin{array}{l}\text { in historic district for Walker Ranch; no } \\
\text { cultural materials } \\
\end{array}$ \\
\hline \multirow{2}{*}{ MJ2 } & \multirow{2}{*}{ 41BX948 } & $0-20$ & 10YR3/2 & \begin{tabular}{|c|} 
very dary \\
grayish brown
\end{tabular} & loamy clay & $\begin{array}{c}\text { roots and } \\
\text { rootlets }\end{array}$ & $\begin{array}{l}\text { wooded terrace at site } 41 \mathrm{BX} 948 ; \text { no cultural } \\
\text { materials }\end{array}$ \\
\hline & & $20-30$ & 10YR3/2 & $\begin{array}{c}\text { very dary } \\
\text { grayish brown }\end{array}$ & loamy clay & $\begin{array}{l}\text { roots and } \\
\text { gravels }\end{array}$ & $\begin{array}{l}\text { no cultural materials and increased gravels } \\
\text { with depth }\end{array}$ \\
\hline \multirow{2}{*}{ MJ3 } & \multirow{2}{*}{ 41BX948 } & $0-20$ & 10YR3/2 & $\begin{array}{c}\text { very dary } \\
\text { grayish brown }\end{array}$ & loamy clay & $\begin{array}{l}\text { roots and } \\
\text { rootlets }\end{array}$ & $\begin{array}{c}\text { wooded terrace at site } 41 \mathrm{BX} 948 ; \text { no cultural } \\
\text { materials }\end{array}$ \\
\hline & & $20-30$ & 10YR3/2 & $\begin{array}{c}\text { very dary } \\
\text { grayish brown }\end{array}$ & loamy clay & $\begin{array}{l}\text { roots and } \\
\text { gravels }\end{array}$ & $\begin{array}{l}\text { no cultural materials and increased gravels } \\
\text { with depth }\end{array}$ \\
\hline $\mathrm{T} 1$ & $41 \mathrm{~B} \times 948$ & $0-25$ & 10YR2/1 & black & clay loam & roots & $\begin{array}{c}\text { near a two-track on a wooded terrace at site } \\
41 \mathrm{BX} 948 ; \text { no cultural materials }\end{array}$ \\
\hline $\mathrm{T} 2$ & 41BX948 & $0-20$ & 10YR2/1 & black & clay loam & $\begin{array}{l}\text { roots and } \\
\text { gravels }\end{array}$ & $\begin{array}{l}\text { wooded terrace at site } 41 \mathrm{BX} 948 \text {; no cultural } \\
\text { materials; degrading bedrock at } 25 \mathrm{cmbs}\end{array}$ \\
\hline \multirow{2}{*}{1} & & $0-28$ & 10YR3/3 & dark brown & clay loam & rootlets & near site41BX1062; east of Sta. No. 180 \\
\hline & & $28-32$ & $5 \mathrm{YR} 4 / 6$ & yellow-red & clay & rootlets & near site41BX1062; east of Sta. No. 180 \\
\hline \multirow{2}{*}{2} & & $0-25$ & 10YR3/3 & dark brown & clay loam & rootlets & near site41BX1062; east of Sta. No. 180 \\
\hline & & $25-30$ & $5 \mathrm{YR} 4 / 6$ & yellow-red & clay & rootlets & near site41BX1062; east of Sta. No. 180 \\
\hline \multirow{2}{*}{3} & & $0-20$ & 10YR3/3 & dark brown & clay loam & rootlets & near site41BX1062; east of Sta. No. 180 \\
\hline & & $20-45$ & $5 \mathrm{YR} 4 / 6$ & yellow-red & clay & rootlets & near site41BX1062; east of Sta. No. 180 \\
\hline \multirow{2}{*}{4} & & $0-20$ & 10YR3/3 & dark brown & clay loam & rootlets & near site41BX1062; east of Sta. No. 180 \\
\hline & & $20-45$ & $5 \mathrm{YR} 4 / 6$ & yellow-red & clay & rootlets & near site41BX1062; east of Sta. No. 180 \\
\hline
\end{tabular}

the adjacent property and demonstrated that the site does not extend northward.

The property in the northwest quadrant of the intersection of Segment 2 and U.S. 281 (also Salado Creek intersection) was inspected and trenching was proposed for what appeared to be an alluvial terrace associated with Salado Creek. However, according to the landowner, Dr. Robert Jones (personal communication, 2007), the landform is an artificial terrace constructed in the 1970s. He also mentioned that THC archaeologists investigated the property before the filling began. After considering the extent of previous disturbances,
SWCA attempted neither a pedestrian survey nor trenching at the locale.

The property on the southwest quadrant of the intersection of Segment 2 and U.S. 281 (the proposed locale for the aforementioned exit/entrance ramp) consists of an active floodplain of Salado Creek and a 100 percent pedestrian survey was accomplished after a recent flooding event (Figure 5.10). No cultural materials were observed in this area. Large boulders were evident not only in the active channel, but also along the adjacent terraces, indicating high volumes of fastmoving water are commonplace in this area. Cutbanks revealed little soil deposition above extensive gravel 


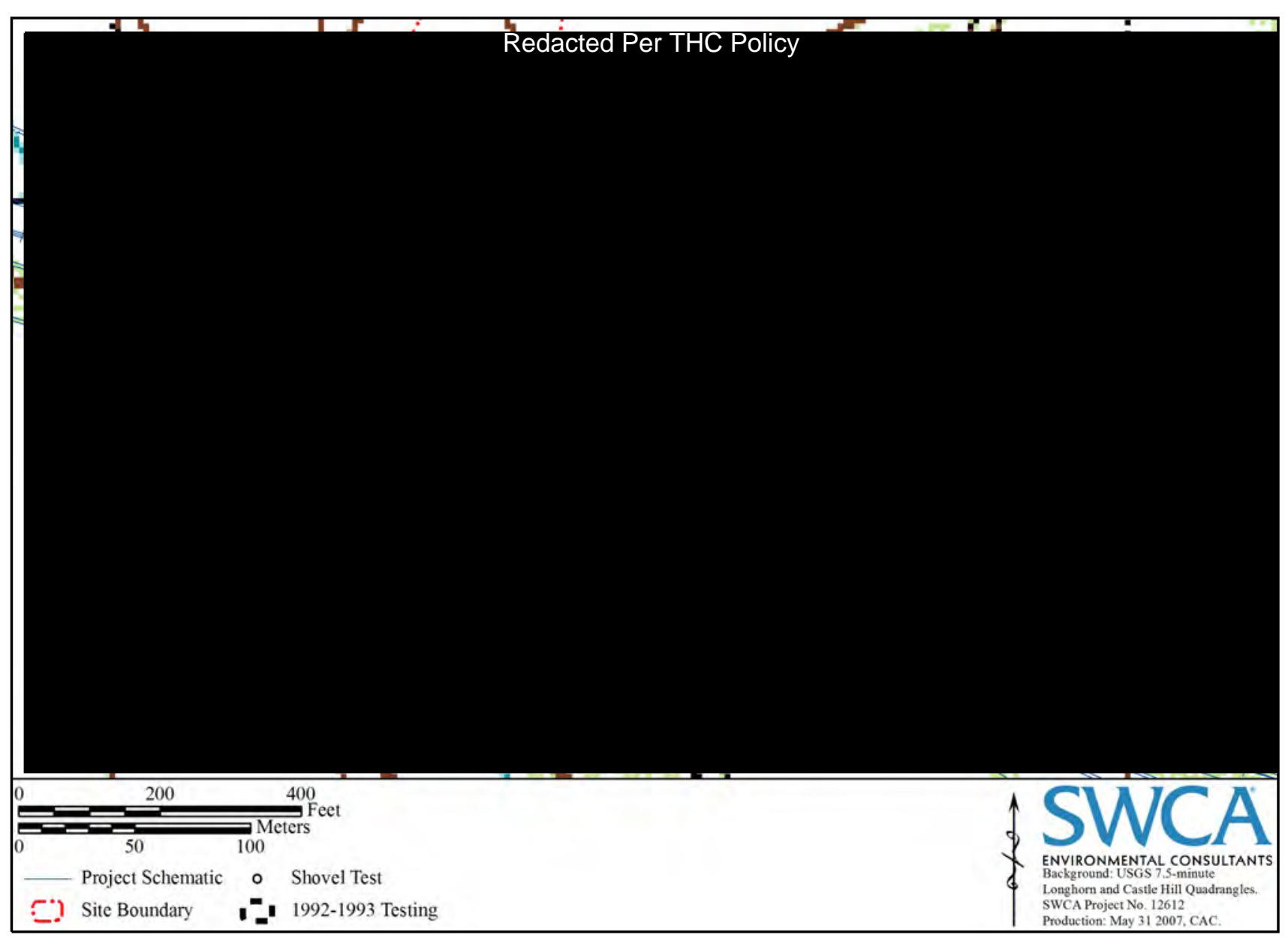

Figure 5.8. 41BX228 site map with shovel test excavations.

deposits (Figure 5.11). For these reasons, trenching was not attempted in this area.

Overall, investigations revealed Segment 2 to have been previously surveyed for archaeological resources and that it currently exhibits extensive disturbances from residential and commercial development. No new archaeological sites were documented.

\section{SITE $41 B X 1062$}

Site 41BX1062 was originally recorded in 1994 by James Karbula of TARL based on systematic shovel testing that revealed two large bovid teeth and mandible fragments, 25-50 mostly burned flakes, burned rock, a biface fragment, and a crude biface (TARL files). No diagnostic projectile points were recovered from the site. One burned rock feature was identified.

Site 41BX1062 was recorded on an elevated ridge of a natural terrace overlooking a paleochannel that once flowed into Salado Creek. Karbula determined the site size as 400 square $m$ and its depth ranged from $20-30$ $\mathrm{cm}$. Fifteen shovel tests and three $1 \times 1-\mathrm{m}$ units were excavated (Figure 5.12). The investigations revealed shallow soils throughout the site and a concentration of cultural materials along the ridge. The single feature identified, burned rocks clustered in a semi-circular arrangement, appeared disturbed by oak roots. No diagnostic artifacts were encountered and Karbula recommended that 41BX1062 was neither eligible for listing on the NRHP nor for designation as an SAL. No further archaeological work was recommended at the site.

At present, site 41BX1062 is surrounded by commercial and residential development. Right of entry was denied at the Coker United Methodist Church property, which precluded a revisit to 41BX1062, located within the APE. However, four shovel tests were excavated in the ROW adjacent to the site and no cultural materials associated with 41BX1062 were detected within the APE during SWCA's current survey. SWCA's assessment concurs with the previous findings of non- 


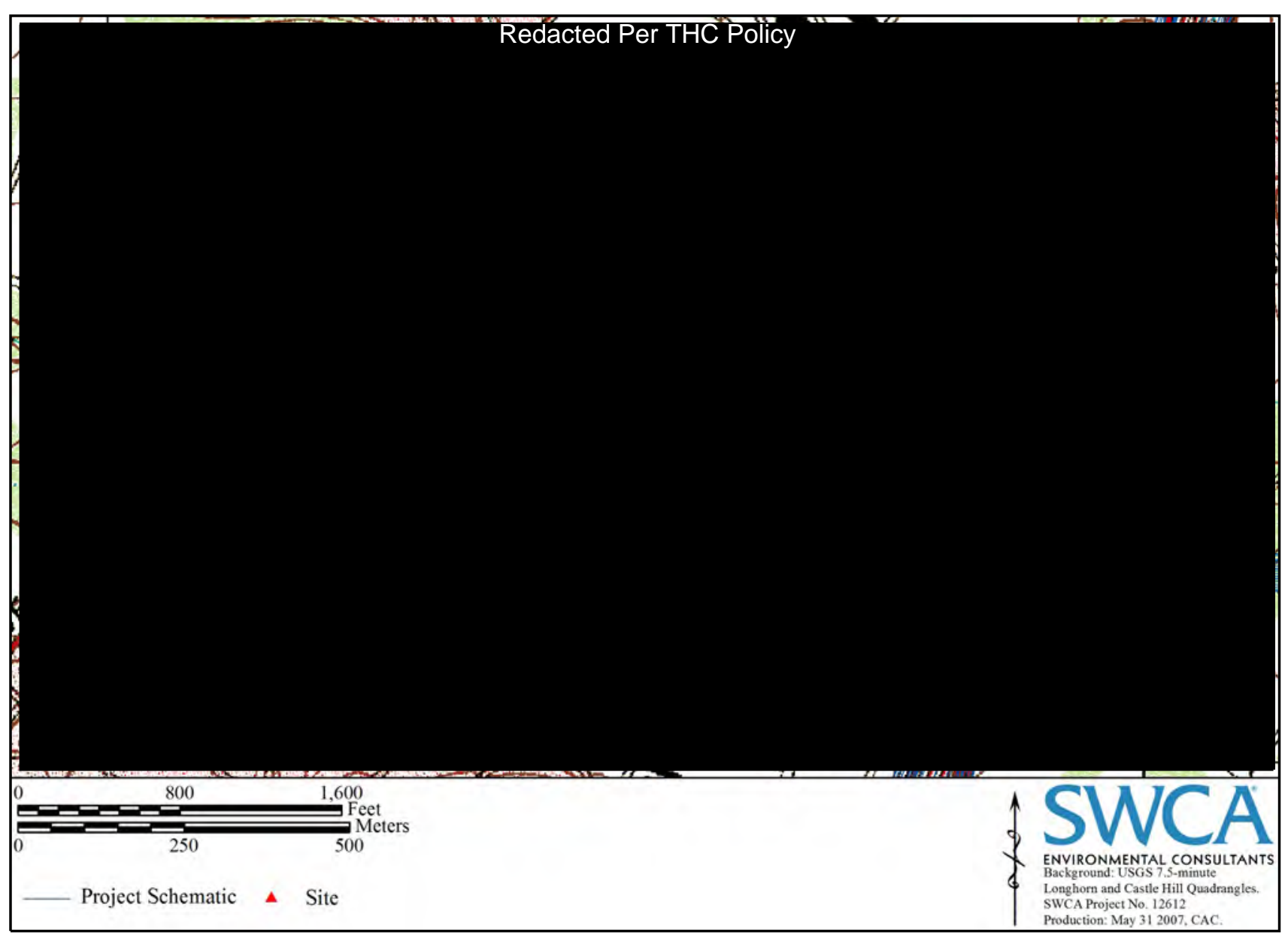

Figure 5.9. Segment 2, Wurzbach Parkway from West Avenue to U.S. 281.

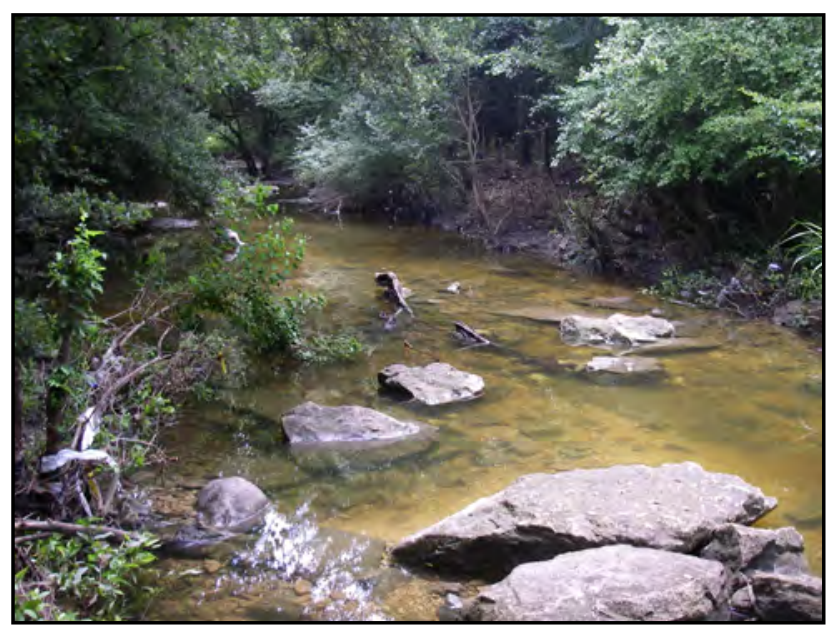

Figure 5.10. Proposed Wurzbach Parkway rightof-way on the west side of U.S. 281 and Salado Creek, facing east.

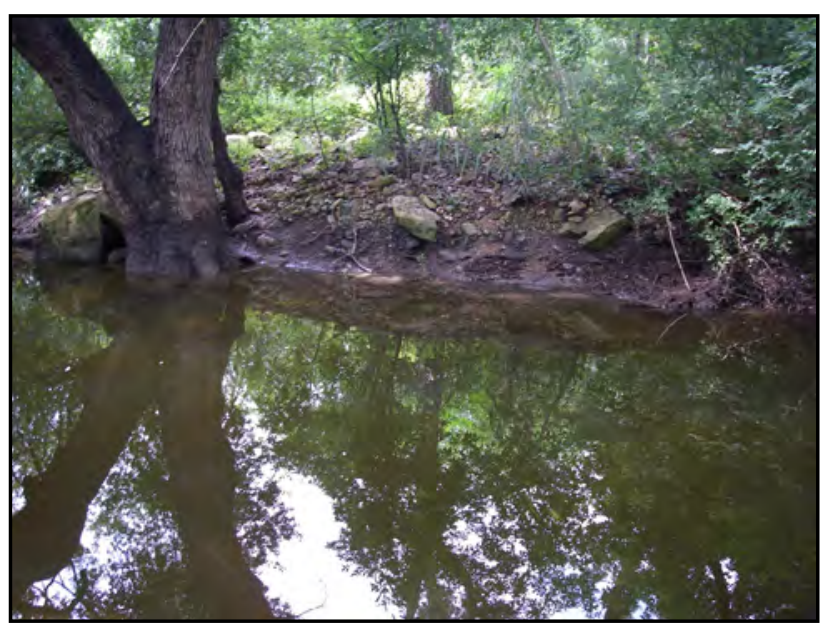

Figure 5.11. Cutbank along Salado Creek on the west side of U.S. 281, facing south. 


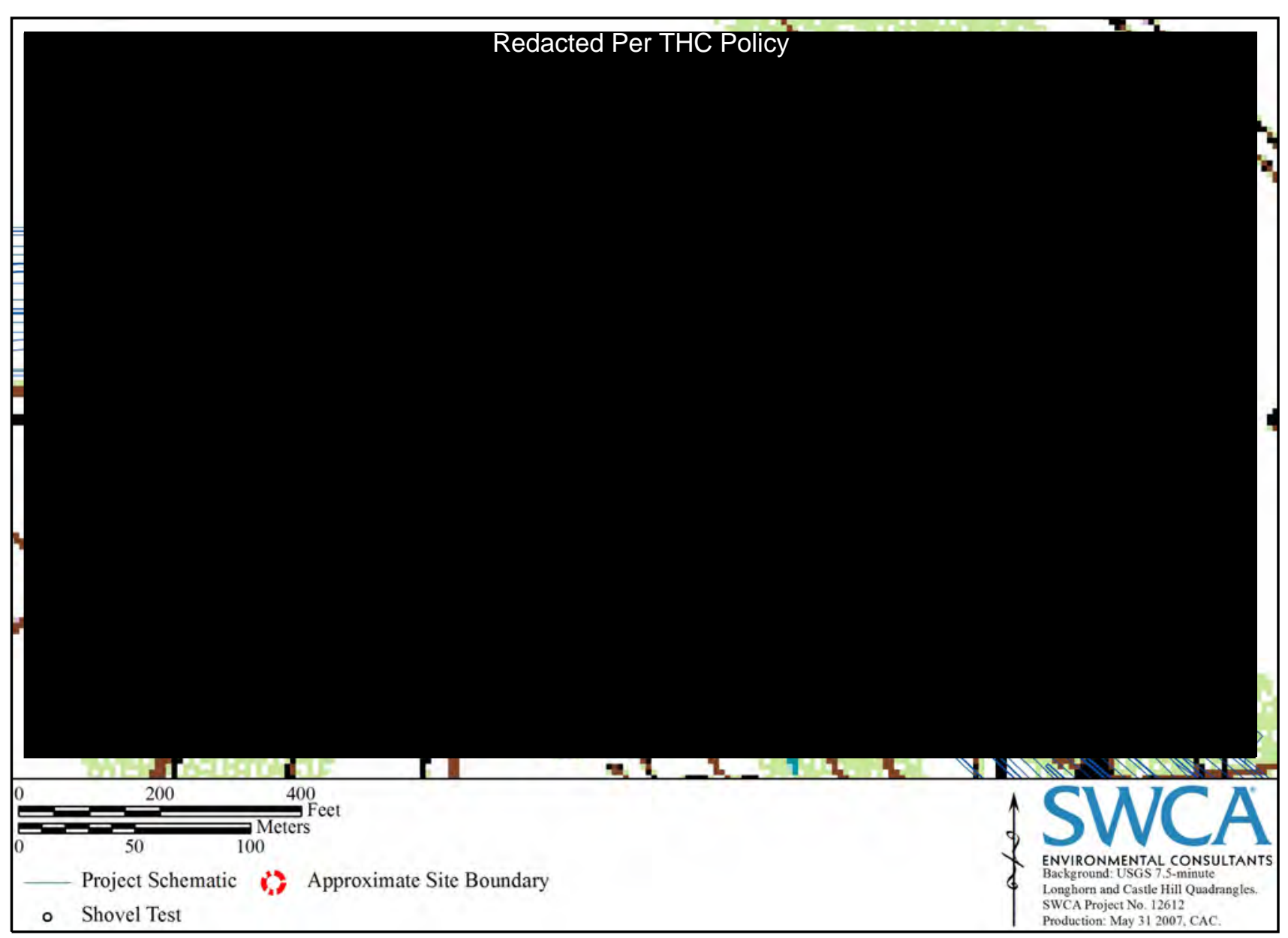

Figure 5.12. Site 41BX1062 site map with shovel test excavations.

significance for this site. The site is not considered eligible for inclusion to the NRHP or for designation as an SAL. No further work is recommended.

\section{Segment 3}

\section{U.S. 281 to Jones Maltsberger RoAd}

Background reviews revealed that much of Segment 3 had been previously surveyed as part of the old Wurzbach Parkway archaeological investigations (Black 1992; Black et al. 1998a; Potter and Black 1995). While these investigations were limited in several areas due to lack of landowner access, two archaeological sites were documented and partially assessed.

A 100 percent pedestrian survey was completed in this section of the APE by SWCA archaeologists. This segment includes property in the southeast quadrant of the intersection of Jones Maltsberger Road and U.S. 281, where a cloverleaf-shaped exit/entrance ramp would be located. The proposed roadway in this area would parallel and cross Salado Creek and would be surrounded by existing commercial and residential development (Figure 5.13). Two previously recorded archaeological sites (41BX947 and 41BX948) are located along this section of the Wurzbach Parkway Extension Project APE. These sites were partially investigated in 1994 and 1995 by TARL; however, a lack of access prevented complete evaluations of each site's eligibility for listing in the NRHP or for designation as an SAL.

Additional shovel testing and backhoe excavations were undertaken during SWCA's current survey to explore the APE in this segment with particular attention to properties that were previously off limits to investigators. The locations of prior site excavations were determined and current excavations were placed to explore adjacent areas. Backhoe trenches were also used to investigate high probability portions of the Salado Creek floodplain and portions of the southeast quadrant of the intersection of Jones Maltsberger Road and U.S. 281. 


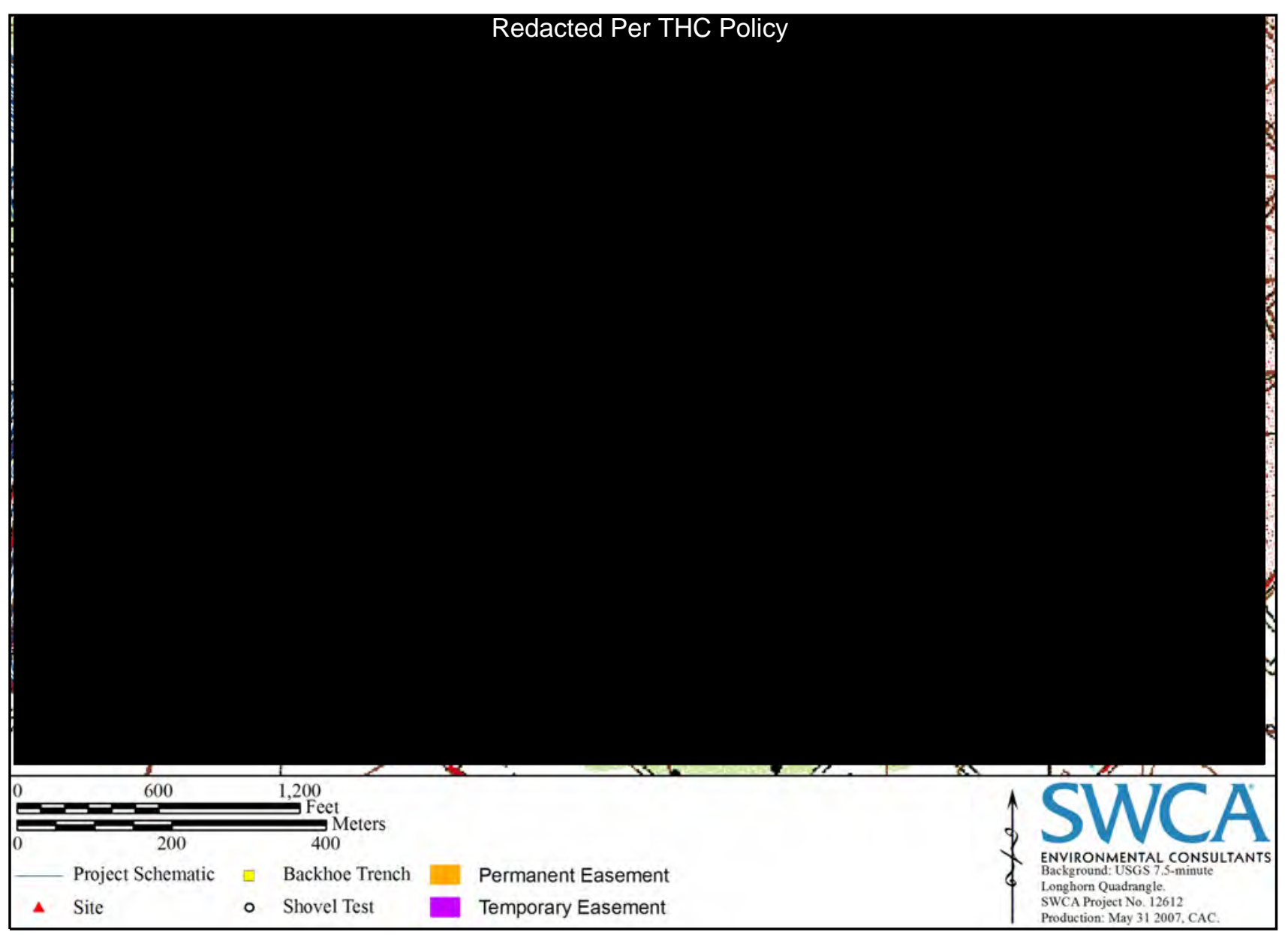

Figure 5.13. Segment 3, Wurzbach Parkway from U.S. 281 to Jones Maltsberger Road.

East of 41BX948 and Coker Loop West, the proposed Wurzbach Parkway Extension Project follows the Salado Creek floodplain with a series of large, recent commercial developments directly adjacent to its southern ROW edge. One backhoe trench (BHT 18) was placed near this section, revealing buried construction debris up to $1 \mathrm{~m}$ deep (Table 5.2, Figure 5.14). On the surface this area has abundant household and construction trash, some exposed bedrock, and stony soils (Figure 5.15). At roughly the midpoint of the segment, a large (3-m-wide) existing concrete drain crosses the APE. A series of backhoe trenches (BHTs 11-18) was excavated along the APE from this drain east to Jones Maltsberger Road (see Figure 5.13). Soils encountered were clay and loam with extensive gravels throughout in BHTs 15-17, which were excavated within the active floodplain of the Salado Creek. Intrusive fills and disturbances were evident in BHTs 11-14, which were excavated on a modified terrace associated with the adjacent commercial development. No cultural materials were encountered in any BHTs in this segment of the ROW. The Salado Creek floodplain and terraces in this segment appear to be high-energy deposits that have been disturbed and in some cases, reworked by local development.

\section{SITE $41 B \times 947$}

Site 41BX947 was originally recorded in 1991 by Frank Weir of the State Department of Highways and Public Transportation (SDHPT) (now TxDOT) based on the observance of three flakes on the surface (TARL files). No diagnostic projectile points were recovered from the site and no features were identified at the time.

Recorded on a low, flat river terrace, the site size was estimated at 5,000 square $\mathrm{m}$. Wier noted that erosional channels revealed cultural material up to $1 \mathrm{~m}$ deep. His determinations were based on the limits of a surficial lithic scatter as his investigations did not include subsurface excavations. Weir recommended further archaeological work at the site as he suspected buried cultural deposits. 


\begin{tabular}{|c|c|c|c|c|c|c|c|c|c|c|c|c|c|c|c|c|c|c|c|c|}
\hline 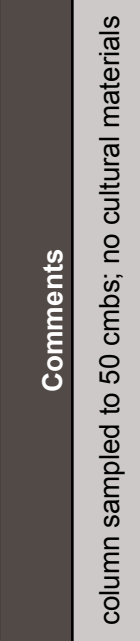 & 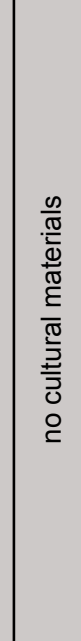 & 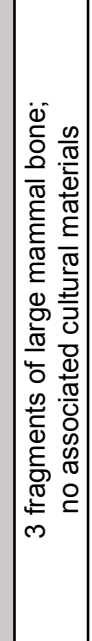 & 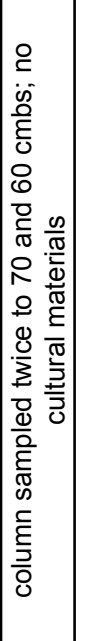 & 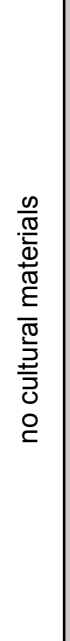 & 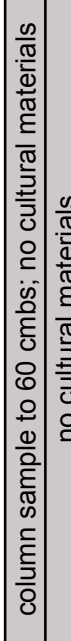 & 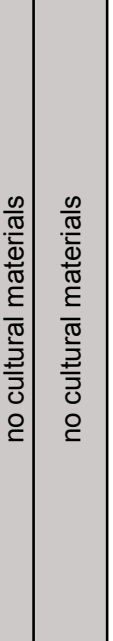 & 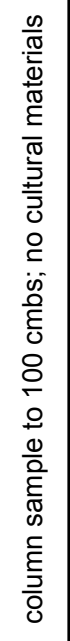 & 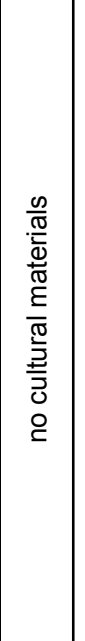 & 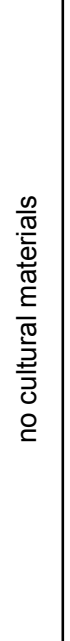 & 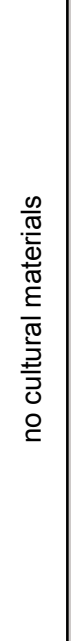 & 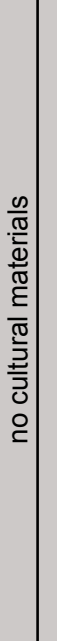 & 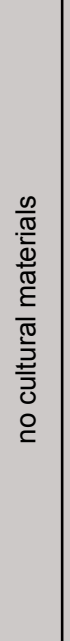 & 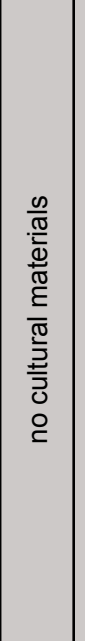 & 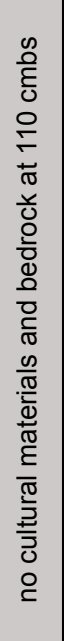 & 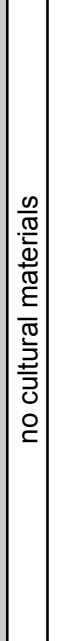 & 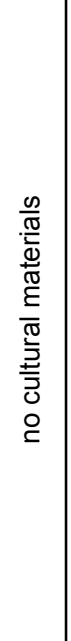 & 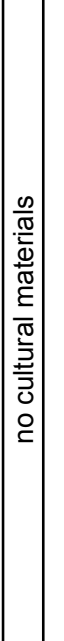 & 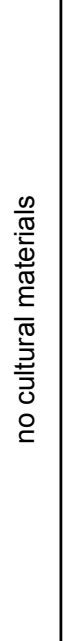 & 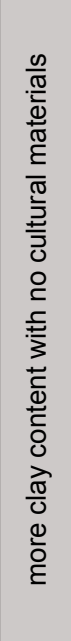 & 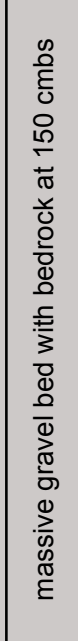 \\
\hline 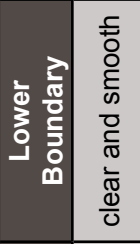 & 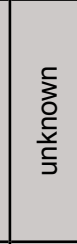 & 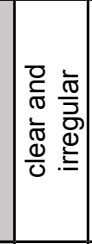 & 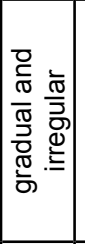 & 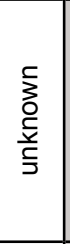 & 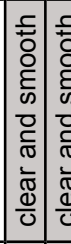 & 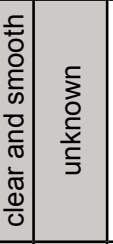 & 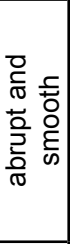 & 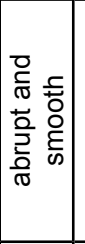 & 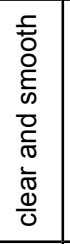 & 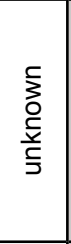 & $\begin{array}{l}3 \\
\frac{3}{3} \\
3 \\
0 \\
\frac{0}{\pi} \\
\frac{2}{\pi} \\
\frac{0}{0} \\
0\end{array}$ & 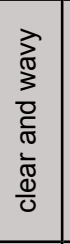 & 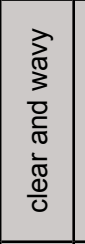 & $\begin{array}{l}\frac{\vec{a}}{2} \\
\frac{0}{\sigma}\end{array}$ & $\left|\begin{array}{l}3 \\
\frac{1}{\pi} \\
3 \\
0 \\
\frac{2}{\pi} \\
\frac{1}{0} \\
\overline{0} \\
\frac{0}{0}\end{array}\right|$ & 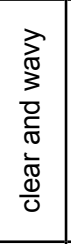 & 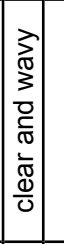 & $\begin{array}{l}\frac{\overrightarrow{0}}{2} \\
\frac{20}{\sigma}\end{array}$ & $\begin{array}{l}\sum_{\pi} \\
\frac{10}{3} \\
0 \\
\frac{0}{\pi} \\
\frac{\pi}{\pi} \\
\frac{0}{0} \\
\frac{\pi}{0} \\
\frac{0}{0}\end{array}$ & $\begin{array}{l}\sum_{\pi}^{2} \\
\frac{\pi}{3} \\
0 \\
\frac{0}{\pi} \\
\frac{0}{2} \\
\frac{2}{2} \\
\frac{0}{\pi}\end{array}$ \\
\hline $\begin{array}{l}\frac{\omega}{0} \\
\frac{0}{0} \\
\frac{\pi}{\pi}\end{array}$ & $\begin{array}{l}\frac{\infty}{0} \\
\stackrel{0}{0} \\
\frac{\pi}{0} \\
\frac{1}{\pi} \\
\frac{\pi}{0} \\
\frac{1}{0} \\
\frac{0}{\pi}\end{array}$ & 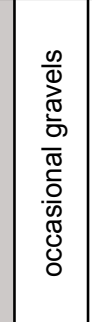 & 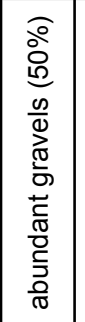 & 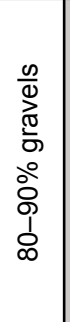 & 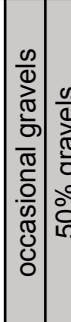 & 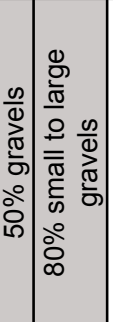 & 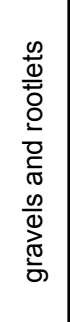 & 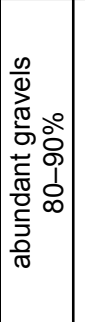 & 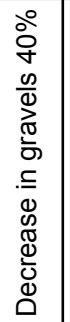 & $\begin{array}{l}\frac{\infty}{0} \\
\stackrel{1}{\pi} \\
\frac{0}{0} \\
\therefore \\
0 \\
\infty \\
0 \\
0 \\
0\end{array}$ & 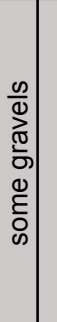 & 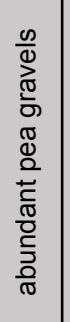 & 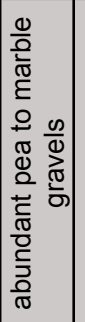 & $\begin{array}{l}\frac{\infty}{0} \\
\stackrel{0}{0} \\
\frac{\pi}{0} \\
\stackrel{0}{0} \\
0 \\
\infty\end{array}$ & $\mid$ & 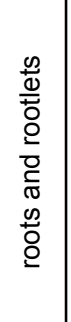 & $\begin{array}{l}\stackrel{0}{0} \\
\stackrel{0}{2}\end{array}$ & $\begin{array}{l}\frac{\infty}{0} \\
\stackrel{\omega}{\infty} \\
\frac{\pi}{0} \\
\stackrel{0}{0} \\
\stackrel{0}{\infty}\end{array}$ & 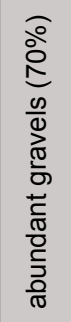 & 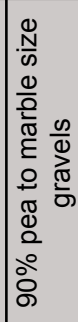 \\
\hline
\end{tabular}

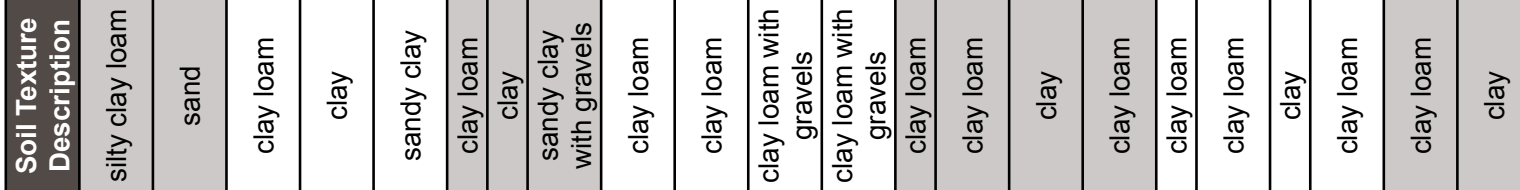

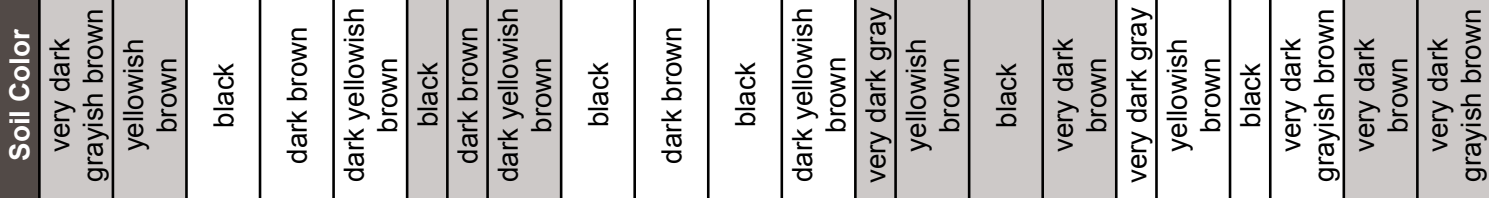

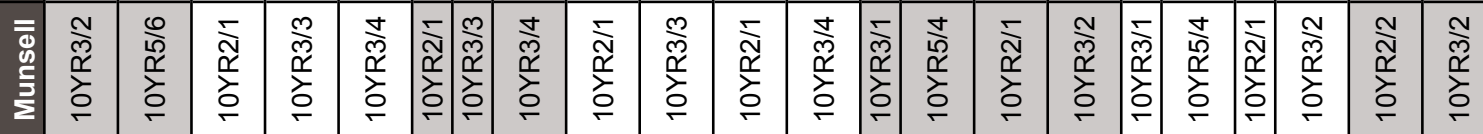

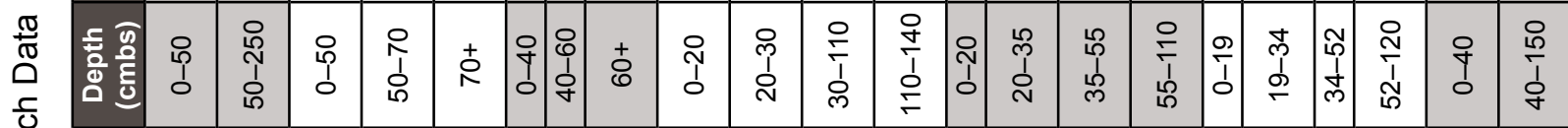
등

\begin{tabular}{|c|c|c|c|c|c|c|c|}
\hline 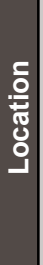 & 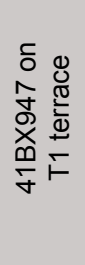 & 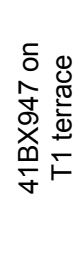 & 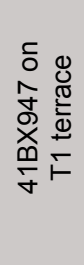 & 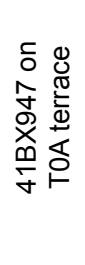 & 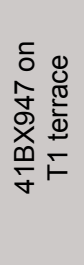 & 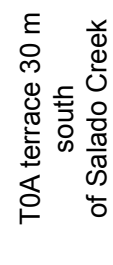 & 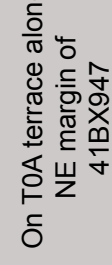 \\
\hline 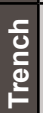 & 宾 & $\begin{array}{l}\stackrel{N}{\text { I }} \\
\underset{\mathbf{I}}{\mathbf{T}}\end{array}$ & $\stackrel{m}{\stackrel{m}{!}}$ & $\begin{array}{l}\stackrel{+}{ } \\
\stackrel{ }{\infty}\end{array}$ & 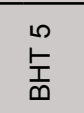 & $\begin{array}{l}0 \\
\stackrel{ }{T} \\
\frac{1}{m}\end{array}$ & 点 \\
\hline
\end{tabular}


a

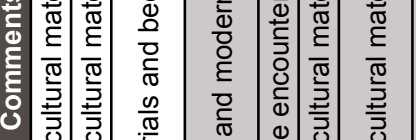

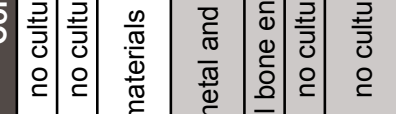
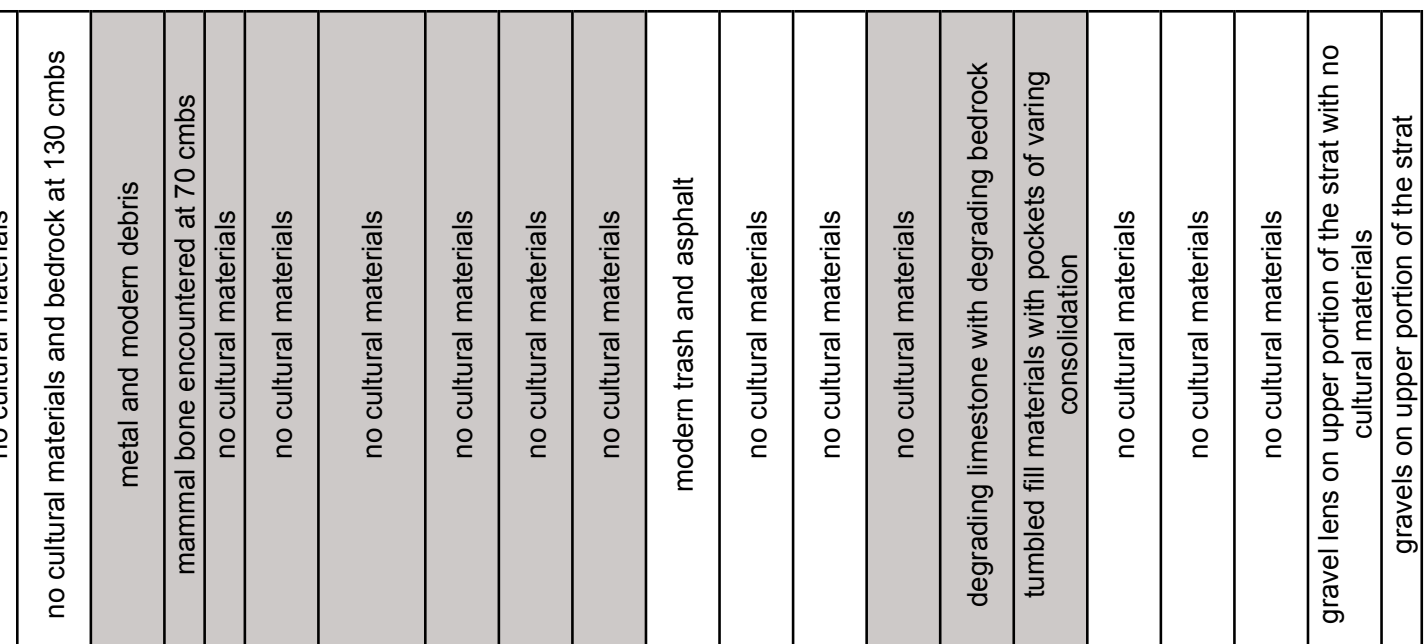

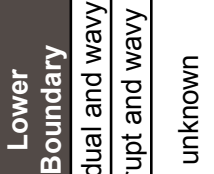
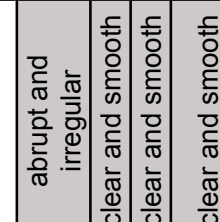

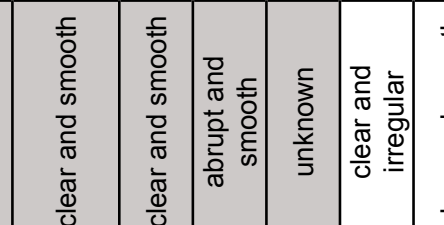

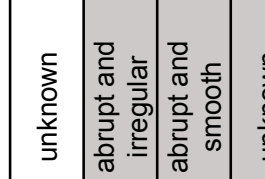

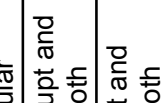

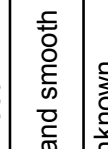
离

$\div \frac{\infty}{0} \div$

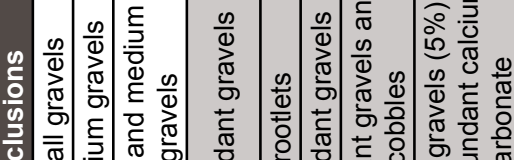

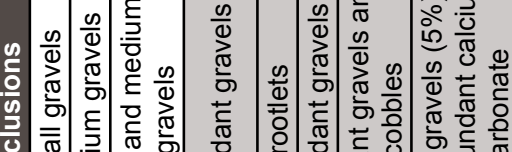

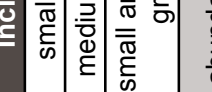

离

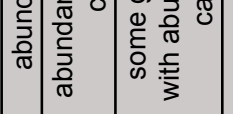

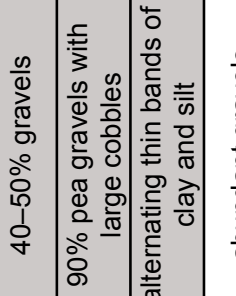

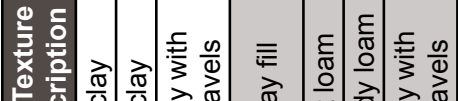

흥

类 $\frac{\pi}{0} \frac{\pi}{0} \frac{\pi}{0}$

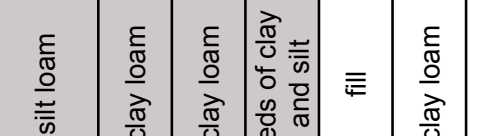

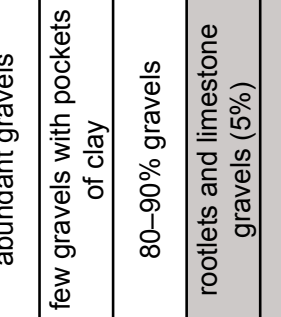

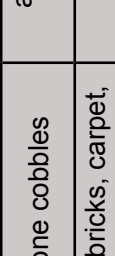

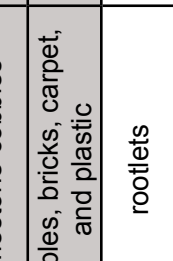

$\frac{1}{2}$

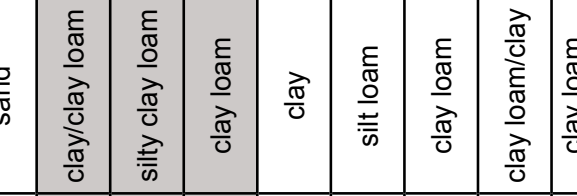

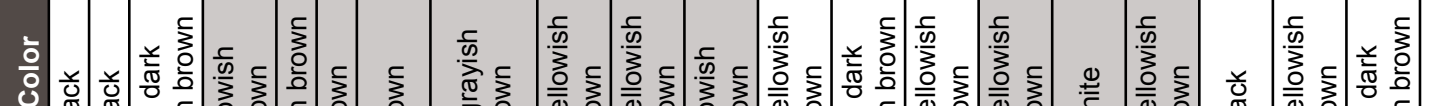

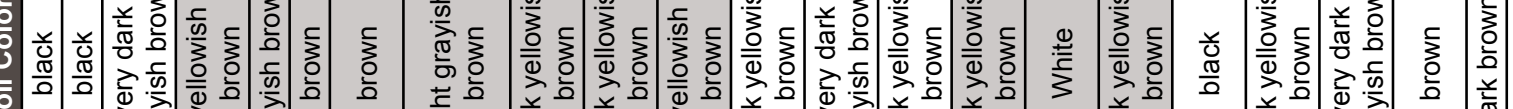

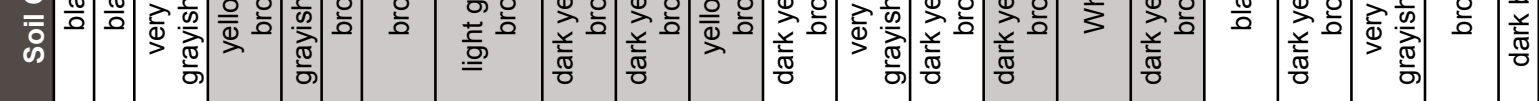

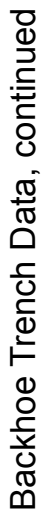

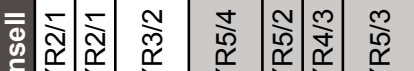

(l)

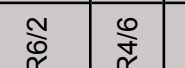

ฮี =

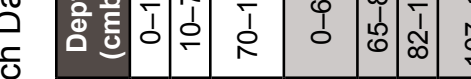

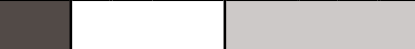

竞

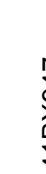

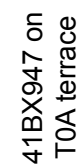

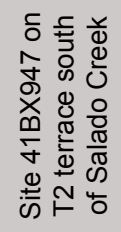

กั

高

날

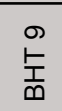

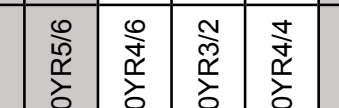

竞

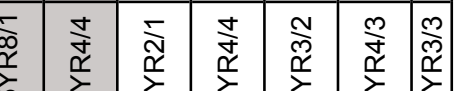

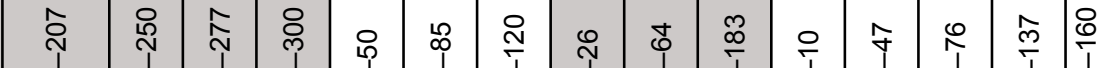

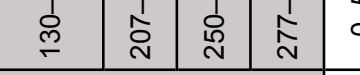




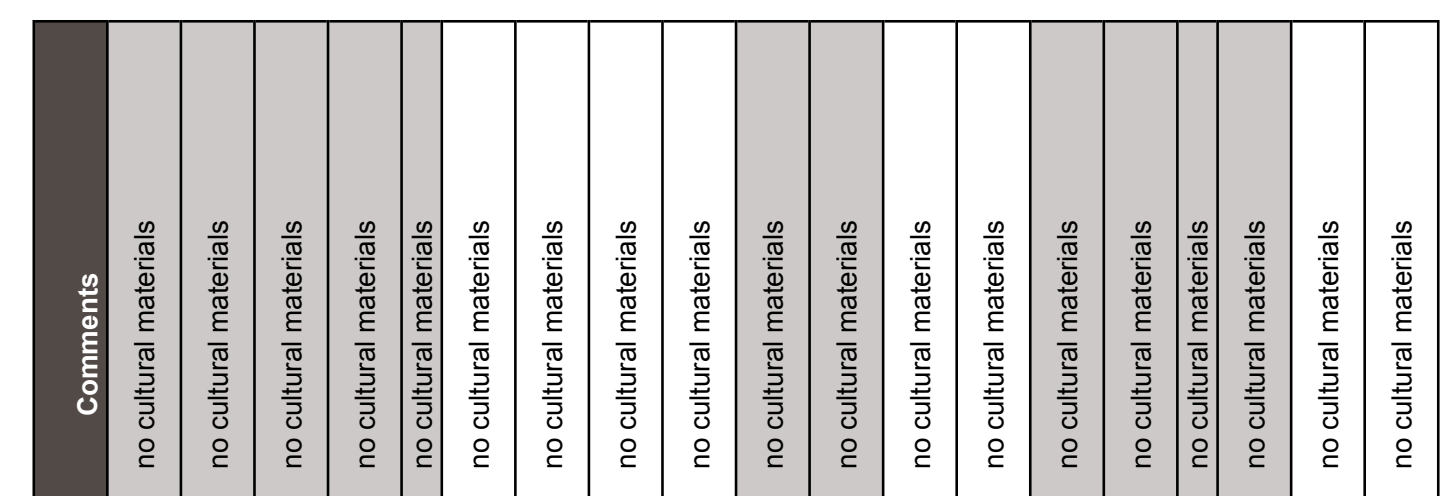

\begin{tabular}{|c|c|c|c|c|c|c|c|c|c|c|c|c|c|c|c|c|c|c|}
\hline 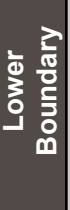 & 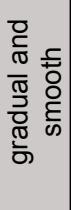 & 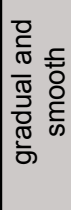 & 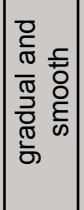 & 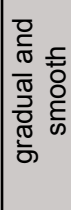 & $\left|\begin{array}{|c|} \\
\frac{3}{3} \\
0 \\
\frac{5}{5} \\
\frac{5}{5}\end{array}\right|$ & 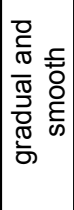 & 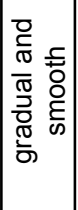 & 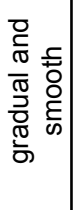 & 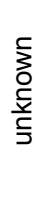 & 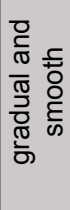 & 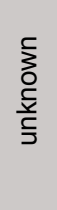 & 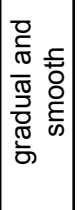 & 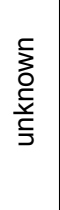 & 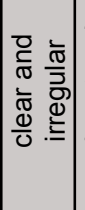 & 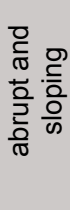 & 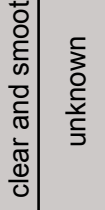 & 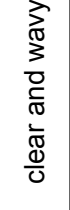 & 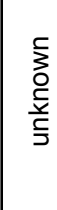 \\
\hline 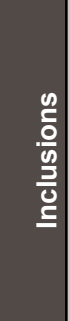 & 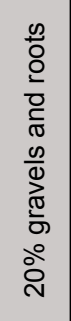 & $\begin{array}{l}\frac{\infty}{0} \\
\stackrel{0}{0} \\
\frac{\pi}{0} \\
\stackrel{0}{0} \\
\infty\end{array}$ & $\begin{array}{l}\frac{\infty}{0} \\
\stackrel{0}{0} \\
\frac{\pi}{0} \\
0 \\
0 \\
\infty\end{array}$ & $\begin{array}{l}\frac{\infty}{0} \\
\stackrel{0}{0} \\
\frac{\pi}{0} \\
\stackrel{0}{0} \\
\frac{0}{1}\end{array}$ & $\left|\begin{array}{|c|c}\frac{0}{0} \\
\stackrel{0}{0} \\
\frac{0}{6} \\
0 \\
0 \\
0 \\
1 \\
0 \\
0\end{array}\right|$ & 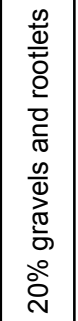 & 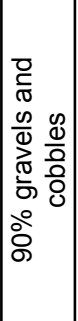 & 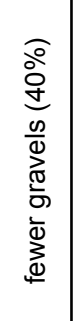 & 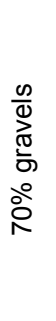 & $\begin{array}{l}\frac{\infty}{0} \\
\stackrel{\pi}{0} \\
\frac{\pi}{0} \\
\stackrel{0}{0} \\
\dot{\sigma}\end{array}$ & 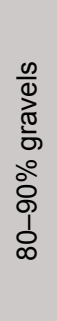 & $\begin{array}{l}\frac{\infty}{0} \\
\stackrel{0}{0} \\
\frac{\pi}{0} \\
\stackrel{0}{0} \\
\dot{+}\end{array}$ & $\begin{array}{l}\frac{\infty}{0} \\
\stackrel{0}{0} \\
\frac{0}{0} \\
\circ \\
\stackrel{0}{0} \\
0 \\
1 \\
\infty\end{array}$ & 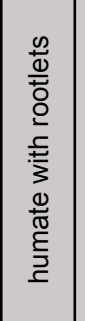 & $\begin{array}{l}\frac{\infty}{0} \\
\stackrel{1}{0} \\
\frac{0}{0} \\
\circ \\
0 \\
0 \\
0 \\
0\end{array}$ & 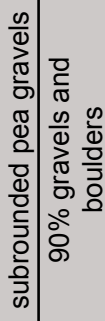 & 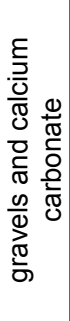 & $\begin{array}{l}\frac{0}{\pi} \\
\frac{0}{0} \\
\frac{0}{0} \\
\frac{0}{0} \\
\frac{5}{0} \\
\frac{\overline{0}}{0}\end{array}$ \\
\hline
\end{tabular}

\begin{tabular}{|c|c|c|c|c|c|c|c|c|c|c|c|c|c|c|c|c|c|c|c|}
\hline 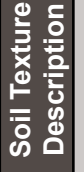 & $\begin{array}{l}\underset{\varepsilon}{\sigma} \\
\stackrel{\delta}{0}\end{array}$ & $\begin{array}{l}\frac{E}{\mathrm{\sigma}} \\
\frac{0}{\mathrm{O}} \\
\frac{\mathrm{\sigma}}{0}\end{array}$ & $\begin{array}{l}\frac{E}{\sigma} \\
\frac{0}{\widehat{\sigma}} \\
\frac{\pi}{0}\end{array}$ & $\begin{array}{l}\frac{\varepsilon}{\pi} \\
\frac{0}{\pi} \\
\frac{\pi}{0}\end{array}$ & $\left|\begin{array}{c|}\frac{\varepsilon}{\pi} \\
\frac{0}{0} \\
\frac{\pi}{0} \\
\frac{\pi}{0}\end{array}\right|$ & $\begin{array}{l}\varepsilon \\
\underline{\widetilde{\Phi}} \\
\underline{\varrho}\end{array}$ & $\begin{array}{l}\frac{E}{\pi} \\
\frac{0}{\pi} \\
\frac{\pi}{0}\end{array}$ & $\begin{array}{l}\frac{E}{\pi} \\
\frac{0}{\partial} \\
\frac{\pi}{0}\end{array}$ & $\begin{array}{l}\frac{E}{\sigma} \\
\frac{0}{\widehat{\sigma}} \\
\frac{\pi}{0}\end{array}$ & $\begin{array}{l}\frac{E}{\bar{\sigma}} \\
\frac{0}{\lambda} \\
\frac{\pi}{0}\end{array}$ & $\begin{array}{l}\frac{E}{\widetilde{\delta}} \\
\frac{0}{\overparen{\pi}} \\
\frac{\pi}{0}\end{array}$ & $\begin{array}{l}\frac{\varepsilon}{\pi} \\
\frac{0}{\partial} \\
\frac{\pi}{0}\end{array}$ & $\begin{array}{l}\frac{E}{\pi} \\
\frac{0}{\overparen{\pi}} \\
\frac{\pi}{0}\end{array}$ & $\begin{array}{l}\underline{\varepsilon} \\
\stackrel{\widetilde{D}}{0}\end{array}$ & $\begin{array}{l}\frac{E}{\pi} \\
\frac{0}{\lambda} \\
\frac{\pi}{0}\end{array}$ & $\mid \begin{array}{l}\frac{\varepsilon}{\sigma} \\
\frac{0}{2} \\
\frac{\pi}{0} \\
\frac{\pi}{0}\end{array}$ & $\begin{array}{l}\frac{E}{\pi} \\
\frac{0}{\lambda} \\
\frac{\pi}{0}\end{array}$ & $\frac{\vec{\pi}}{0}$ & $\frac{\vec{\sigma}}{0}$ \\
\hline 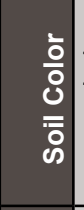 & 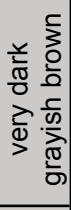 & 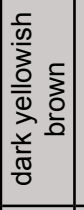 & 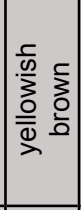 & 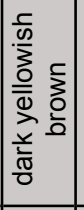 & 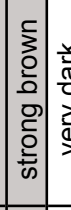 & 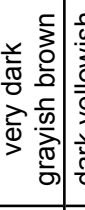 & 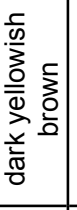 & 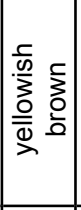 & 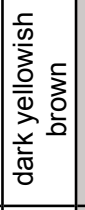 & 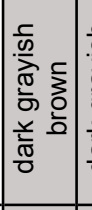 & 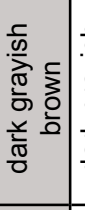 & 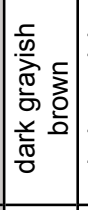 & 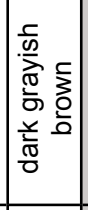 & $\begin{array}{l}\text { 㒸 } \\
\frac{\pi}{0}\end{array}$ & 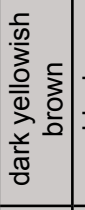 & \begin{tabular}{|l|} 
\\
$\frac{2}{0}$ \\
$\frac{\pi}{0}$ \\
\end{tabular} & $\begin{array}{l}\frac{V}{0} \\
\frac{\pi}{0}\end{array}$ & 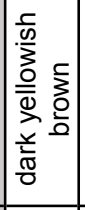 & 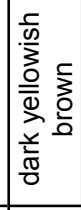 \\
\hline \begin{tabular}{l|}
$\bar{\Phi}$ \\
\\
0 \\
$\bar{z}$ \\
$\Sigma$
\end{tabular} & $\begin{array}{l}\stackrel{N}{\mathcal{N}} \\
\stackrel{\underline{\mu}}{\partial} \\
\underline{0}\end{array}$ & 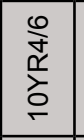 & 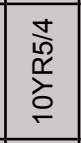 & 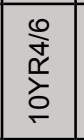 & 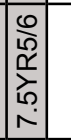 & 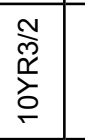 & 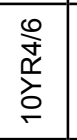 & 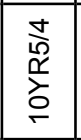 & 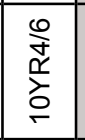 & $\begin{array}{l}\stackrel{N}{\mathbb{f}} \\
\stackrel{\underline{\alpha}}{\underline{\alpha}} \\
\underline{0}\end{array}$ & 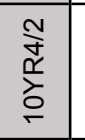 & 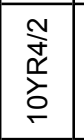 & $\begin{array}{l}\frac{\sigma}{d} \\
\frac{0}{\mathcal{N}} \\
\frac{N}{\alpha}\end{array}$ & 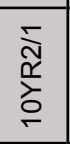 & 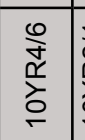 & 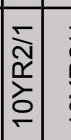 & $\begin{array}{l}\bar{\nwarrow} \\
\stackrel{\Sigma}{\underline{\alpha}} \\
\underline{\underline{\alpha}}\end{array}$ & 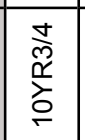 & 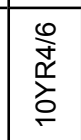 \\
\hline 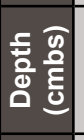 & 广্] & 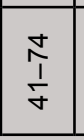 & $\frac{O}{\frac{O}{1}}$ & 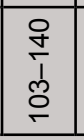 & 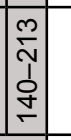 & $\begin{array}{l}\stackrel{N}{N} \\
0\end{array}$ & $\begin{array}{l}\stackrel{8}{0} \\
\grave{N}\end{array}$ & $\begin{array}{l}\text { ○ } \\
1 \\
8 \\
8\end{array}$ & $\frac{\stackrel{8}{+}}{\frac{1}{8}}$ & 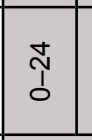 & $\frac{\stackrel{8}{1}}{\stackrel{1}{d}}$ & 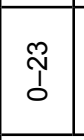 & 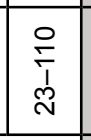 & $\hat{\jmath}$ & ஸे & $\begin{array}{c}0 \\
\vdots \\
1 \\
\sim \\
\widehat{N}\end{array} \mid$ & $\frac{\stackrel{\circ}{m}}{\frac{1}{1}}$ & $\stackrel{\circ}{\frac{1}{1}}$ & 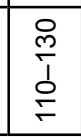 \\
\hline ㅎํㅇ & & & 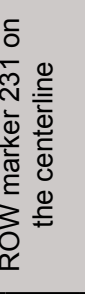 & & & & 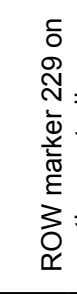 & & & 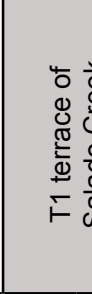 & 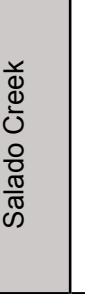 & 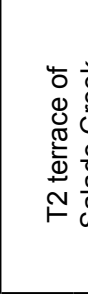 & $\begin{array}{l}\frac{\check{0}}{0} \\
\frac{0}{0} \\
0 \\
\frac{0}{0} \\
\frac{\pi}{\pi} \\
\tilde{N}\end{array}$ & & 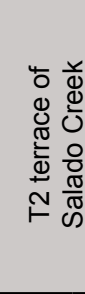 & & & 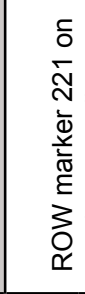 & 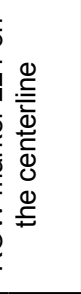 \\
\hline $\begin{array}{l}\frac{}{0} \\
\frac{\overline{0}}{6} \\
\text { के }\end{array}$ & & & $\frac{m}{\frac{m}{5}}$ & & & & 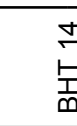 & & & $\begin{array}{l}\frac{10}{5} \\
\text { 卓 } \\
\frac{1}{n}\end{array}$ & & $\begin{array}{l}\frac{0}{5} \\
\frac{1}{\frac{1}{n}}\end{array}$ & $\frac{2}{\frac{2}{T}}$ & & 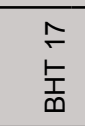 & & & $\stackrel{\infty}{\frac{1}{1}}$ & $\frac{\infty}{\frac{1}{a}}$ \\
\hline
\end{tabular}




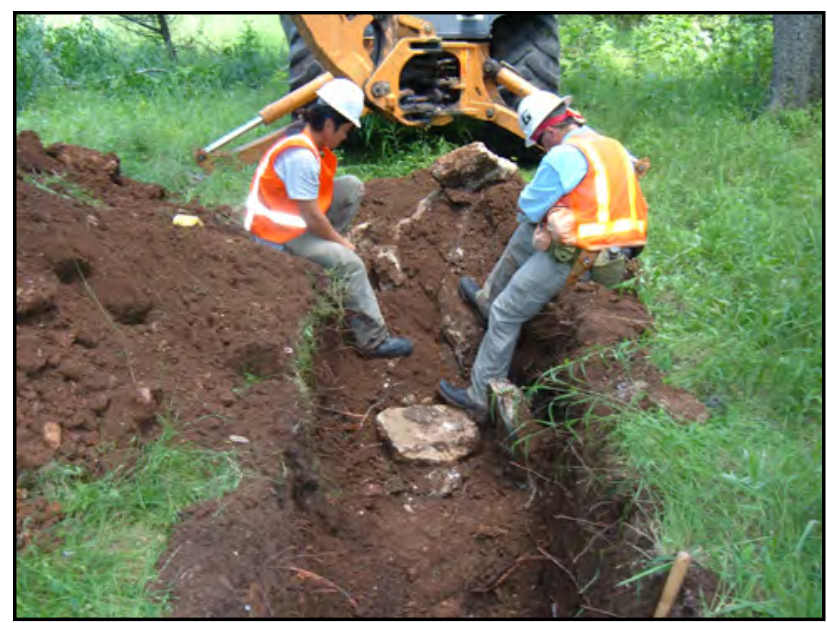

Figure 5.14. Concrete fragments, tile, and other building materials were encountered at $1 \mathrm{~m}$ deep in $\mathrm{BHT} 18$, facing east.

As part of the Wurzbach Parkway project for TxDOT, archaeologists from TARL investigated 41BX947 in 1995 , but they were limited to investigating select portions of the site (Black et al. 1998a). TARL identified the area potentially encompassing the site as from U.S. 281 east to a steep limestone slope. They excavated nine trenches in this area and identified two cultural components at the site. A rockless hearth from Component A was dated to between A.D. 1440 and 1670. A charred nut from the same component in another trench was dated to between A.D. 1400 and 1630. Other features of this component were determined to be burned tree roots or stumps. The older Component B was dated to between 1680 and 1260 B.c. and contained sparse burned rock, a large blade-like flake, and charcoal. Burned tree roots or stumps were also encountered.

Black et al. (1998a:91) characterizes the recovery of cultural materials at 41BX947 as "meager, and probably below the threshold necessary to make useful archaeological interpretations." However, recommendations about the site's eligibility for inclusion in the NRHP or for designation as an SAL were not attempted because the areas north and east of the site could not be investigated. At present, site 41BX947 is surrounded by wooded Salado Creek floodplain and commercial and residential development. Ten backhoe trenches were excavated to explore areas that were previously inaccessible to TARL archaeologists (Figures 5.16 through 5.20; see Table 5.2). Of the trenches excavated at the site, four each were placed on the $\mathrm{T}_{0}$ and $\mathrm{T}_{1}$ terraces, and two others were on the $\mathrm{T}_{2}$ terrace. Bone fragments from a large mammal were recovered in BHT 2 and BHT 9 in the top $70 \mathrm{~cm}$; however, no cultural materials were associated with the bone in either trench. The bone itself appeared to be recent in origin with little weathering but an exact determination as to species (cow or bison) could not be made. No cultural materials associated with 41BX947 were detected within the APE during SWCA's current survey. Considering the sum of the past (Black et al. 1998a) and present investigations, which utilized 19 backhoe trenches and intensive inspections, SWCA does not consider the site eligible for inclusion to the NRHP or for designation as an SAL and no further work is recommended.

\section{SITE $41 B X 948$}

Site 41BX948 was also recorded in 1991 by Weir based on the observance of occasional burned rock, flakes, core fragments, a Clear Fork gouge, and a Nolan projectile point fragment on the surface (TARL files). No features were identified.

Site 41BX948 was recorded on a high terrace bluff overlooking Salado Creek. Weir estimated the site size as 2,000 square $\mathrm{m}$ and, based on the excavation of a shovel test and the examination of erosional exposures, determined the site depth to be at least $40 \mathrm{~cm}$. Weir recommended further archaeological work at the site as he suspected buried cultural deposits.

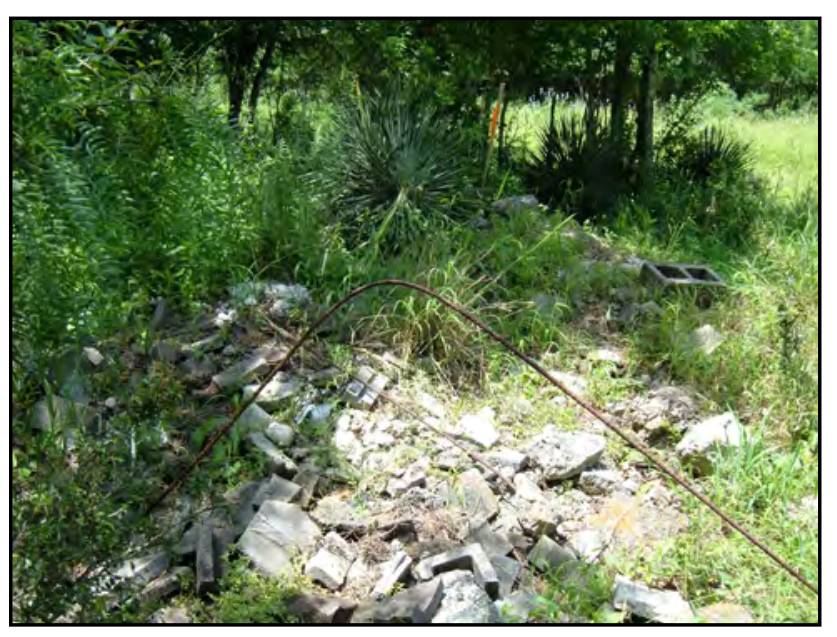

Figure 5.15. Construction debris in the right-ofway at Station No. 221, facing north. Between Station Nos. 220 and 228, the right-of-way is characterized by stony soils, occasional exposed bedrock, and trash of all kinds. 


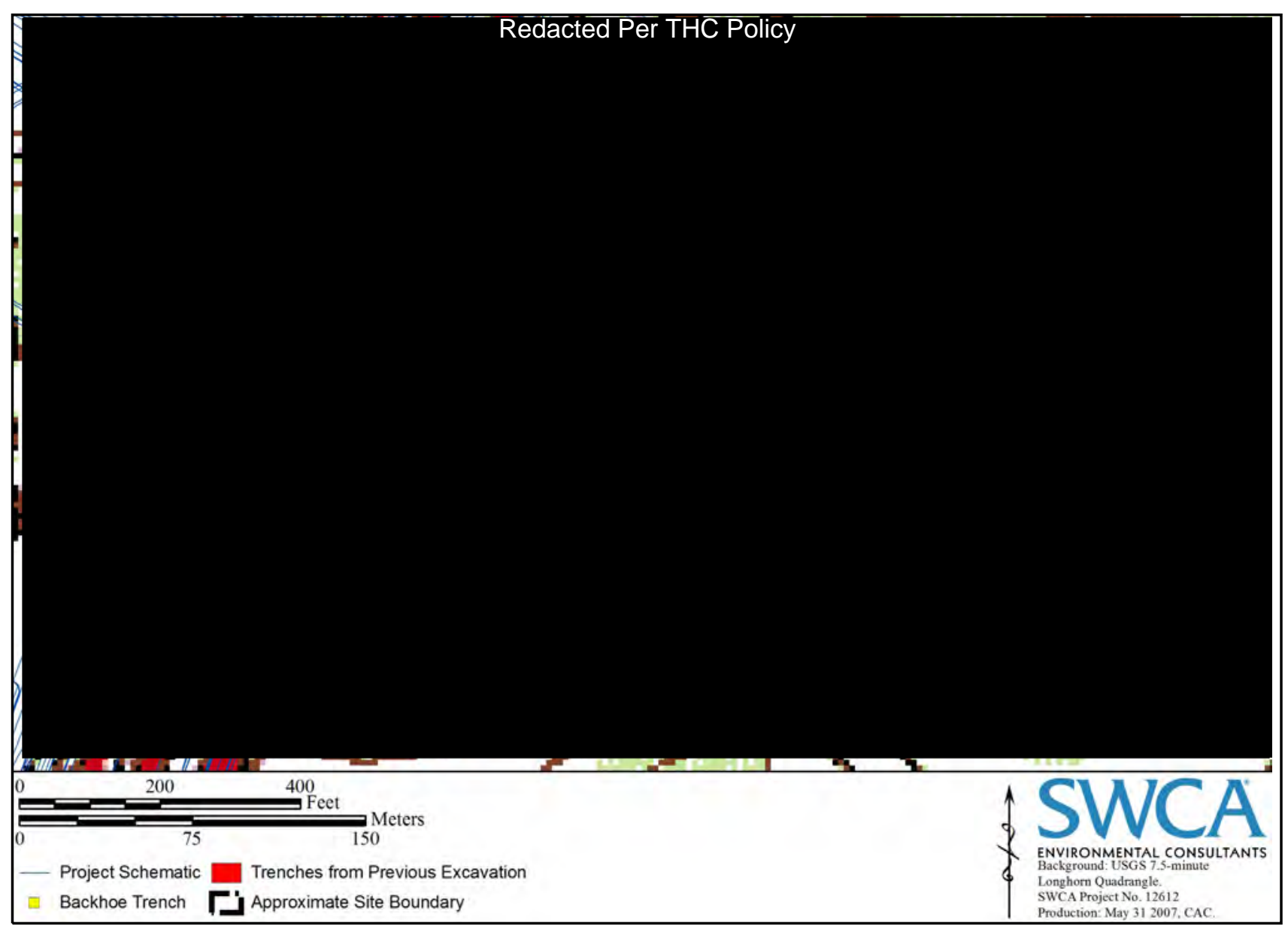

Figure 5.16. Site 41BX947 map with trench excavations.

Archaeologists from TARL investigated 41BX948 in 1994, but they were could not fully investigate all portions of the site (Black et al. 1998a). No access was granted for a portion of the ROW that was still occupied by a residence with a landscaped yard that included a pool. They excavated 14 shovel tests in a fenced area. Investigators encountered scattered burned rocks and flakes in the upper $40 \mathrm{~cm}$ of sediment, but no tools, artifact concentrations, features, or diagnostic artifacts indicative of intact cultural deposits or components.

Black et al. (1998a:94) characterizes the recovery of cultural materials at 41BX948 as "very low density and might represent the fringe areas of a larger site." Recommendations about the site's eligibility for inclusion in the NRHP or for designation as an SAL were not attempted because the areas south and west of the site could not be investigated.

At present, site 41BX948 is a wooded residential lot surrounded by commercial development. The afore- mentioned home has been removed from the ROW. Seven shovel tests were excavated by SWCA to explore areas that were previously inaccessible to TARL archaeologists (Figures 5.21 through 5.23; see Table 5.1). No cultural materials associated with 41BX948

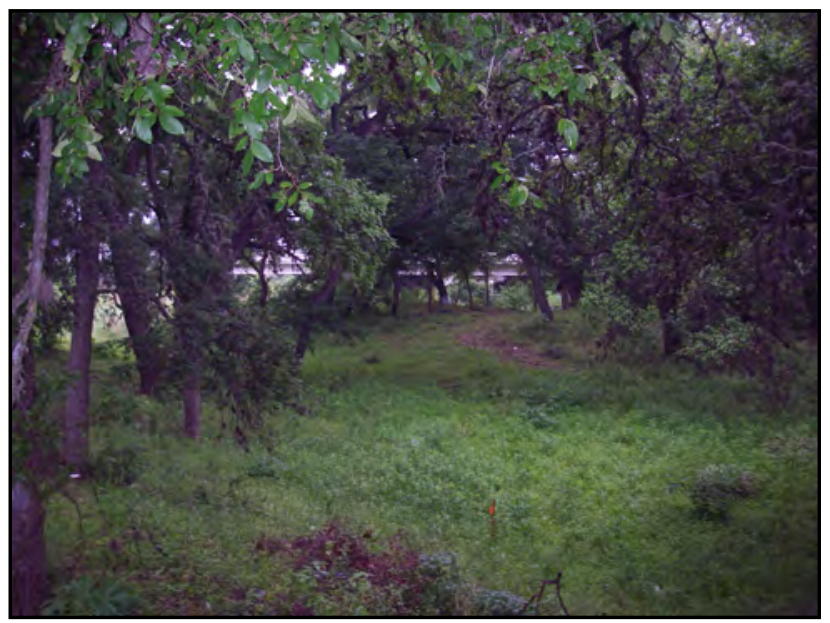

Figure 5.17. Proposed Wurzbach Parkway rightof-way at site 41BX947 near U.S. 281 and Salado Creek, facing west. 


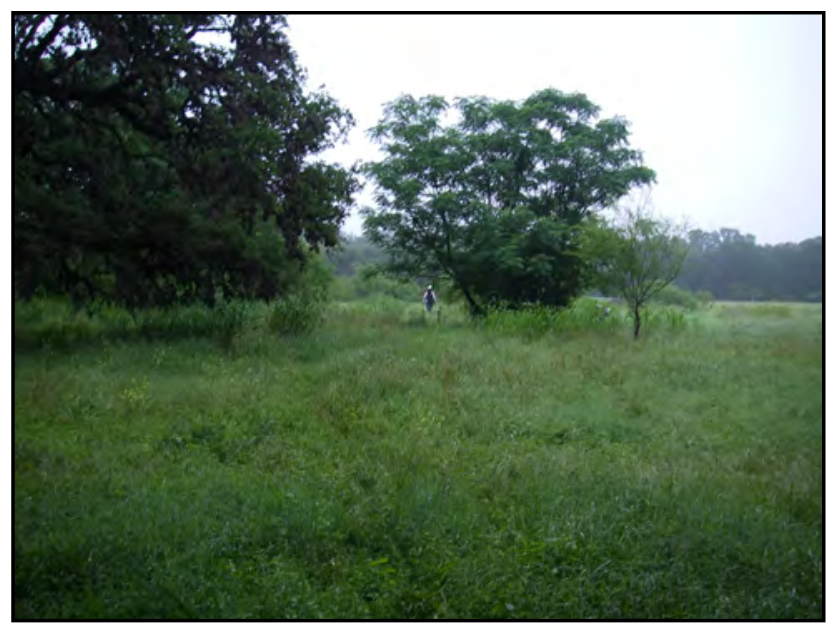

Figure 5.18. Proposed Wurzbach Parkway rightof-way at site 41BX947 near U.S. 281 and Salado Creek, facing east. BHTs 9 and 10 were excavated in this area.

were detected within the APE during SWCA's current survey. Considering the sum of the past (Black et al. 1998a) and present investigations, SWCA does not consider the site eligible for inclusion to the NRHP or for designation as an SAL and no further work is recommended.

Two permanent easements were surveyed by TxDOT within Segment 3, both along the south side of the APE. Locale 3 is a 0.403 -acre easement at Jones Maltsberger Road and Salado Creek. Locale 2 is 0.929 acre in size and about 900 feet west of Locale 3. No cultural materials were encountered within these easements.

\section{SEgment 4}

\section{Jones Maltsberger RoAd to Wetmore ROAD}

Background reviews revealed this entire segment had been previously surveyed as part of numerous archaeological investigations related to commercial and land development including a linear survey undertaken for the FHWA in 1991. A previously recorded archaeological site, 41BX949 is located along this section of the Wurzbach Parkway Extension Project APE. As presented in detail below, TARL archaeologist tested 41BX949 in 1992 (Potter and Black 1995). The proposed roadway in this area would parallel segments of Salado Creek and would be surrounded by existing commercial development (Figure 5.24). There are extensive previous disturbances from quarrying and landfill activities in this segment, many of which have

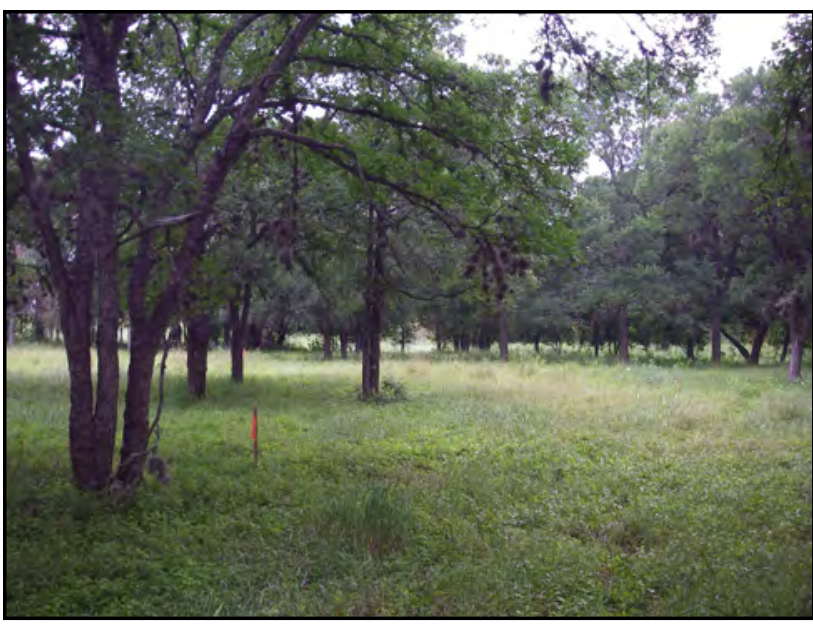

Figure 5.19. Proposed Wurzbach Parkway rightof-way at site 41BX947, facing west. BHTs 1-3 were excavated in this area.

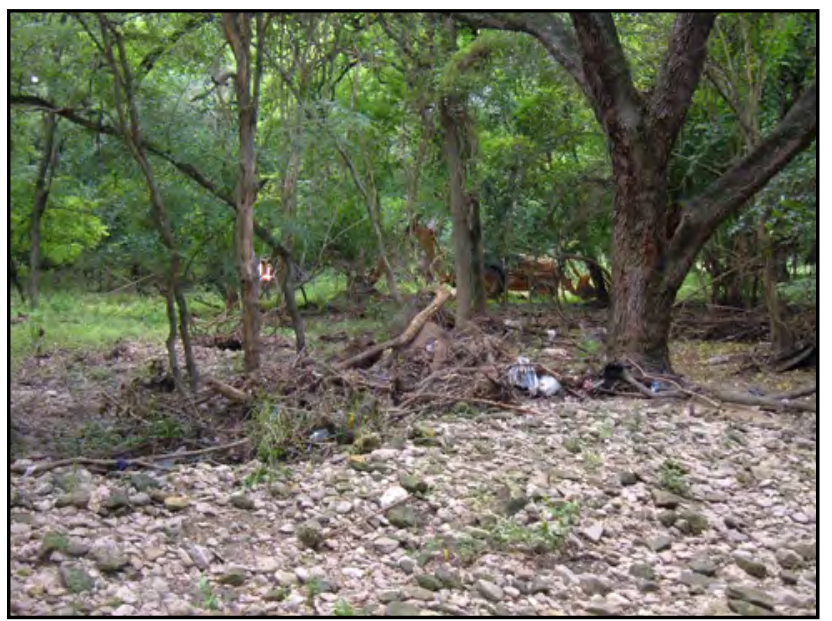

Figure 5.20. Proposed Wurzbach Parkway rightof-way near site 41BX947, facing south. BHTs 4-6 were excavated in this area near the confluence of Salado Creek and a relict channel.

been noted by previous studies (Carpenter and French 2003). Between Starcrest Road and Wetmore Road the segment follows existing roadway with no potential for intact archaeological sites.

Based on the previous investigations and the level of severe disturbances in this segment, only a reconnaissance-level survey was completed in this section of the APE by SWCA archaeologists. Disturbances were documented and areas that appeared relatively intact were inspected but no subsurface excavations were done. The ROW in Segment 4 between Jones Maltsberger and Bitters roads contains small mesquite trees, tall grass, and wildflowers. The ROW appears 


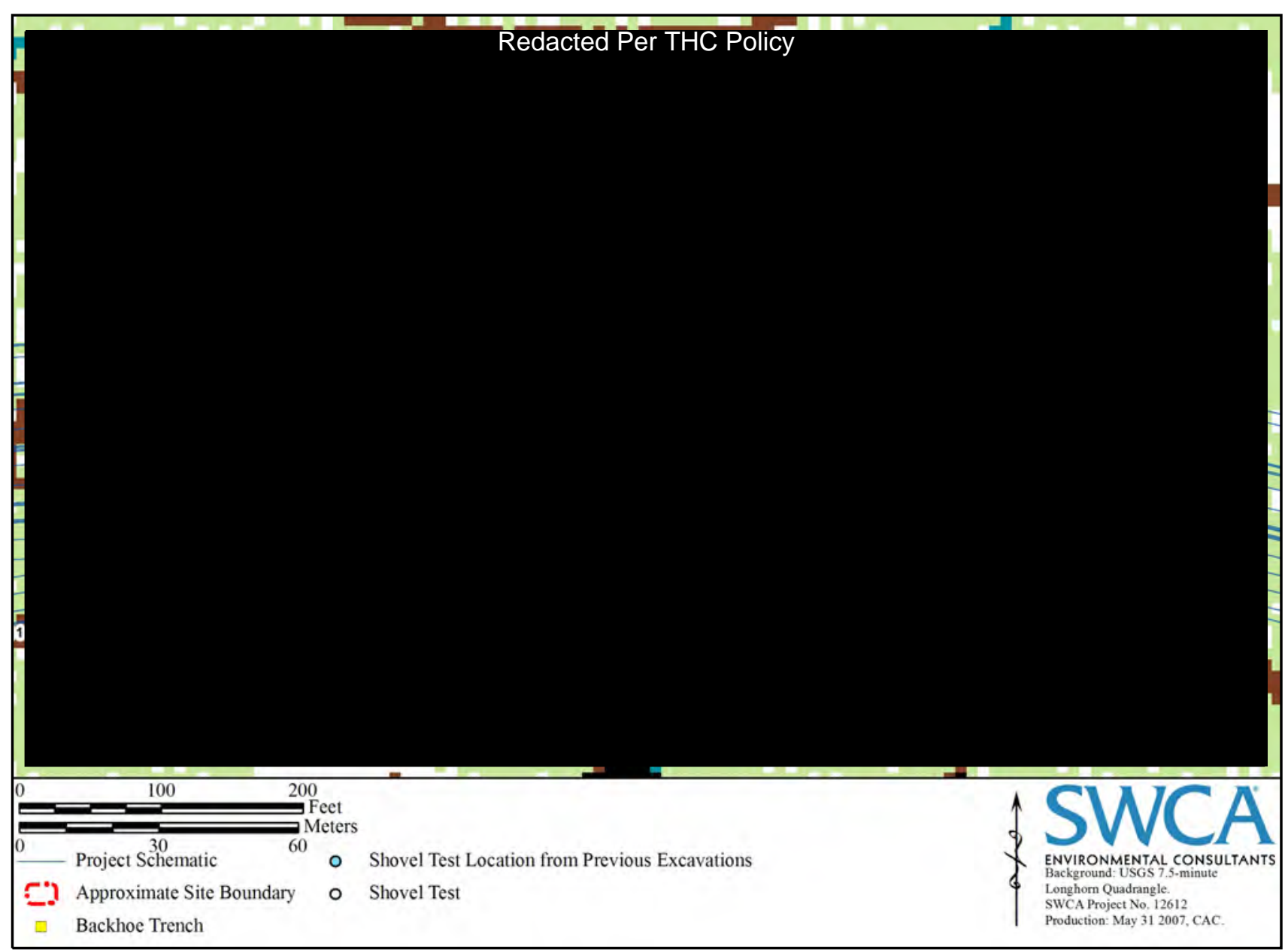

Figure 5.21. Site 41BX948 map and excavations.

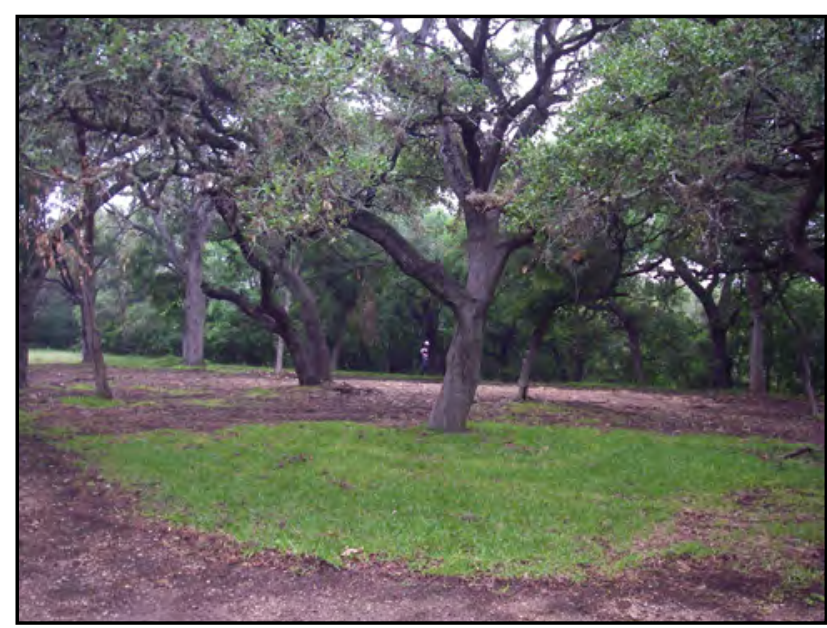

Figure 5.22. Proposed Wurzbach Parkway rightof-way near site 41BX948, facing west. Crew member is standing on the centerline at the edge of the terrace overlooking the relict channel of Salado Creek.

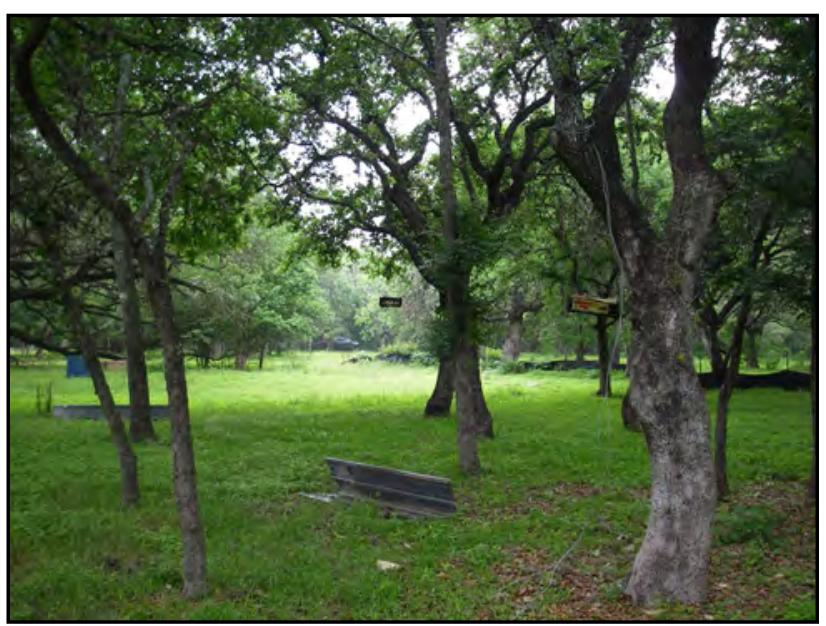

Figure 5.23. Proposed Wurzbach Parkway rightof-way near site 41BX948, facing east. Six negative shovel tests were excavated in this area. 


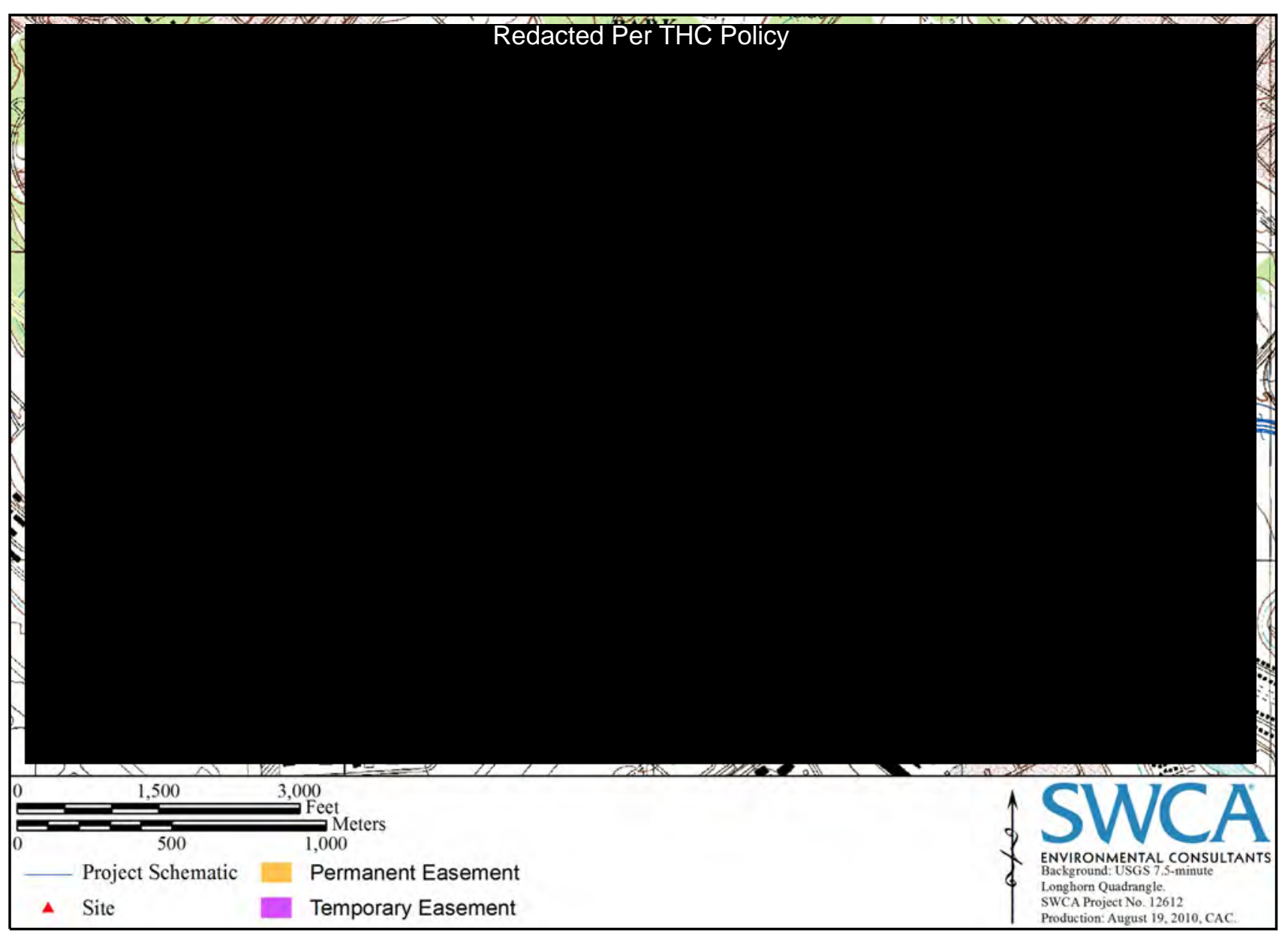

Figure 5.24. Segment 4, Wurzbach Parkway from Jones Maltsberger to Wetmore Road.

to have been disturbed by the removal of vegetation, as large oak trees border the ROW to the southwest, while commercial and recreational developments line the opposite side of the ROW and Bitters Road. Northeast of Bitters Road the APE traverses San Antonio Municipal Airport property that contains large oaks and maintained grassy areas. No new archaeological sites were encountered in Segment 4.

\section{SITE $41 B \times 949$}

Site 41BX949 was recorded in 1991 by Weir of SDHPT based on the observance of burned rock, flakes, bifaces, cores, core fragments, and mussel shell on the surface (TARL files). No diagnostic projectile points were recovered from the site and no features were identified.

Site 41BX949 was recorded on a terrace at the confluence of Salado Creek and an unnamed tributary. Weir estimated the site size as 4,000 square $\mathrm{m}$ and, based on the examination of erosional exposures, determined the site depth to be about $1 \mathrm{~m}$. His conclusions were based on the limits of a surficial lithic scatter as his investigations did not include subsurface excavations. Weir recommended further archaeological work at the site as he suspected buried cultural deposits.

In 1992, TARL tested 41BX949 as part of a comprehensive testing program of five sites along the proposed Wurzbach Parkway (Potter and Black 1995). The testing involved the excavation of nine shovel tests and five backhoe trenches. Their investigations produced a total of 10 unmodified flakes, an edge-damaged flake, and a thin biface fragment (Potter and Black 1995:13). The cultural materials were so few in number that the investigators were unable to define meaningful site limits or even confirm that a discrete archaeological site existed at this locale (Potter and Black 1995:13). The excavations revealed no significant or intact deposits at site 41BX949. Accordingly, no further work was recommended, and the site was not deemed eligible for inclusion to the NRHP or for listing as an SAL. 
At present, site 41BX949 is on undeveloped airport property, which is wooded with maintained grassy areas. Site 41BX949 was surveyed at a reconnaissance level because previous testing (Potter and Black 1995) produced an extremely low frequency of artifacts in extensive hand and machine excavations and no meaningful site limits were defined. SWCA's assessment concurs with the previous findings of non-significance for this site, and no further work is recommended.

Eight temporary easements and two permanent ones were surveyed along both sides of the APE by TxDOT within Segment 4. Locale 4 is along Bitters Road at Salado Creek and consists of a 2.275-acre temporary easement north of the APE and a 28.965-acre temporary easement south of it. Adjacent to the east, Locale 5 is roughly centered at the intersection of Starcrest Drive and the northeast entrance to the San Antonio International Airport. It consists of a 0.292-acre temporary easement north of the APE and four easements (two each permanent and temporary) south of it, totaling 4.227 acres in size. Locale A is a temporary easement along the north side of the APE and includes portions of Bitters Road and the entrance to a brush collection area. Locale B consists of two temporary easements along both sides of the APE east of Jones Maltsberger Road, parallel to Bitters Road, and south of the Northside ISD sports complex. No cultural materials were encountered within these easements. 


\section{Chapter 6}

\section{Summary AND Recommendations}

\section{Segment 1 \\ Blanco Road to West Avenue}

Ten previously recorded archaeological sites are within or directly adjacent to the ROW in this segment of the proposed Wurzbach Parkway Extension APE: 41BX181, 41BX183, 41BX184, 41BX194, 41BX202, 41BX203, 41BX209, 41BX222, 41BX223, and 41BX228 (see Figure 5.1). No evidence of eight of these sites was encountered within the APE; however, the remnants of two of these, 41BX184 and 41BX228, were relocated during the current SWCA survey. Another site 41BX202 is documented within the Wurzbach Parkway Extension Project APE; however, bridge and road construction subsequent to its being recorded have left no remaining intact landforms associated with the site.

Scattered non-diagnostic lithic debris is evident within the known boundaries of $41 \mathrm{BX} 184$ as are recent looter's pits. The surface of 41BX228 continues to reveal lithic debris and diagnostic projectile points like the two fragments collected during this survey (see Figure 5.7); however, no evidence of significant buried cultural resources was evident in any shovel test excavated at the site.

Both 41BX184 and 41BX228 were extensively excavated in the 1990s (Black and McGraw 1985; Black et al. 1998a; Potter and Black 1995). Overall, investigations by Black et al. (1998a) at 41BX184 and by Black and McGraw (1985) and Potter and Black (1995) at 41BX228 covered the current proposed Wurzbach Parkway Extension Project APE, mitigating potential roadway construction impacts with their extensive excavations. In fact, Potter and Black (1995) recommended that 41BX228 was no longer worthy of being listed as a contributing member of the Walker Ranch National Historic District. SWCA's assessment concurs with the previous findings for this site. Therefore, $41 \mathrm{BX} 228$ is no longer considered eligible for inclusion to the NRHP or for designation as an SAL and no further work is recommended.
Given the extent of previous investigations (Black et al. 1998a) and subsequent looting of the site, the remaining portion of $41 \mathrm{BX} 184$ within the ROW is not considered significant and does not contribute to its eligibility for inclusion to the NRHP or for designation as an SAL. SWCA recommends no further work at $41 \mathrm{BX} 184$.

The permanent easement in Segment 1 surveyed by TxDOT exhibited prior disturbance from land clearing and the construction of a Soil Conservation Service floodwater retarding structure. No cultural materials were encountered within the easement and no further work is recommended at this location.

As no properties were identified that meet the criteria for listing on the NRHP according to 36 Code of Federal Regulations (CFR) 60.4 or for designation as a SAL according to 13 TAC 26.12, no further work is recommended for Segment 1 of the proposed Wurzbach Parkway Extension Project.

\section{Segment 2 \\ West Avenue to U.S. 281}

One previously recorded archaeological site, 41BX1062, is within the ROW in this segment of the proposed Wurzbach Parkway Extension Project APE. Right of entry for survey was not granted by several landowners along this segment of APE. For this reason, inspection of 41BX1062 was not possible. However, after testing in 1994, Karbula recommend that 41BX1062 was neither eligible for listing on the NRHP nor for designation as an SAL. No further archaeological work was recommended at that time.

The ROW exhibits extensive disturbances from West Avenue for about $450 \mathrm{~m}$ east where land clearing, fill dumping, and earth moving are evident. Site 41BX1062 is about $150 \mathrm{~m}$ east of this disturbed area, near a church parking lot. No cultural materials associated with the site were detected within the APE during 
SWCA's current survey. SWCA's assessment concurs with the previous findings of non-significance for this site. Therefore, the site is not considered eligible for inclusion to the NRHP or for designation as an SAL and no further work is recommended.

Although right of entry was not granted by several landowners in Segment 2, these properties represent upland terrain, with shallow, rocky soils. These areas have also been previously surveyed and no archaeological sites were found. As no properties were identified that meet the criteria for listing on the NRHP according to 36 CFR 60.4 or for designation as a SAL according to 13 TAC 26.12, no further work is recommended for Segment 2 of the proposed Wurzbach Parkway Extension Project.

\section{SEgment 3}

\section{U.S. 281 to Jones Maltsberger RoAd}

Two previously recorded archaeological sites (41BX947 and 41BX948) are located along this section of the Wurzbach Parkway APE. These sites were partially investigated in 1994 and 1995 by CAR; however, lack of access prevented complete evaluations of the sites' eligibility for listing in the NRHP or for designation as SALs.

Ten backhoe trenches were excavated by SWCA to explore areas of 41BX947 that were previously inaccessible to TARL archaeologists. Six shovel tests were excavated within areas of 41BX948 that were previously inaccessible. No cultural materials associated with 41BX947 or 41BX948 were detected within the APE during SWCA's current survey. Therefore, neither site is considered eligible for inclusion to the NRHP or for designation as an SAL and no further work is recommended.

Intensive survey of the remainder of Segment 3 revealed no archaeological sites. Eight backhoe trenches were placed along high probability areas along Salado Creek between Coker Loop West and Jones Maltsberger Road. No cultural materials were recovered from any BHTs in this segment of the ROW.

Two permanent easements were surveyed by TxDOT within Segment 3, both along the south side of the APE. Locale 3 is located in the frequently flooded $\mathrm{T}_{0}$ and $\mathrm{T}_{1}$ floodplain of Salado Creek with numerous exposures of gravel bars. Locale 2 includes an asphalt parking lot for the adjacent commercial development. No cultural materials were encountered within these easements.

As no properties were identified that meet the criteria for listing on the NRHP according to 36 CFR 60.4 or for designation as a SAL according to 13 TAC 26.12, no further work is recommended for Segment 3 of the proposed Wurzbach Parkway Extension Project.

\section{Segment 4 \\ Jones Maltsberger Road to Wetmore ROAD}

This segment of the proposed Wurzbach Parkway Extension would parallel portions of Salado Creek and crosses extensively modified and disturbed areas, including landfills and quarries. Potential for intact, significant undiscovered archaeological sites in this segment is non-existent. Numerous previous investigations in this area recorded one archaeological site, 41BX949, along this segment of the APE.

Previous testing excavations (Potter and Black 1995) at 41BX949 revealed no significant or intact deposits at this site. Accordingly, no further work was recommended and 41BX949 was deemed not eligible for inclusion to the NRHP or for designation as an SAL (Potter and Black 1995). SWCA's assessment concurs with the previous findings of non-significance for this site and no further work is recommended.

Eight temporary easements and two permanent ones were investigated along both sides of the APE by TxDOT within Segment 4. Locale 4 consists of two temporary easements north and south of the APE. Locale 4 represents an illegal dump site in the high-energy and frequently flooded flood plain of Salado Creek. Locale 5 consists of a temporary easement north of the APE and four easements (two each permanent and temporary) south of it. The temporary easement north of the APE consists of undeveloped city property previously cleared by bulldozing and removing trees. The easements south of the APE are within the frequently flooded $\mathrm{T}_{0}$ flood plain of Salado Creek with numerous exposures of relic gravel bars and stream-rolled cobbles on the surface. Locale A is a temporary easement along the north side of the APE that includes portions of an existing city street and a driveway. This easement has been previously disturbed by land clearing and road construction. Locale B consists of two temporary 
easements along both sides of the APE that are along an upland margin and parallel to Bitters Road. To the south, the easement includes the western approach to an existing driveway entrance for a city brush dump. It has been previously disturbed by land clearing and brush removal. To the north, the easement has been previously cleared and leveled as portions of an undeveloped business park and sports complex adjacent to Bitters Road. No cultural materials were encountered within these easements.

As no properties were identified that meet the criteria for listing on the NRHP according to 36 CFR 60.4 or for designation as an SAL according to 13 TAC 26.12, no further work is recommended for Segment 4 of the proposed Wurzbach Parkway Extension Project.

\section{Conclusion}

In accordance with Section 106, 36 CFR 800.4, SWCA and TxDOT have made a reasonable and good faith effort to identify archaeological historic properties within the Wurzbach Parkway Extension Project APE. As no properties were identified that meet the criteria for listing on the NRHP according to 36 CFR 60.4 or for designation as an SAL according to 13 TAC 26.12, no archeological historic properties are affected and SWCA recommends no further work for the 5.3-mile Wurzbach Parkway Extension Project APE.

In the event that previously undiscovered archaeological remains are discovered during construction, work in the area of discovery shall cease and emergency discovery procedures will be implemented under the terms and conditions of the Programmatic Agreement between TxDOT, the THC, FHWA, and the Advisory Council on Historic Preservation. 



\section{REFERENCES}

Abbott, P., and C. M. Woodruff, eds.

1986 The Balcones Escarpment: Geology, Hydrology, Ecology. Geological Society of America, San Antonio.

Baumgartner, D. H., and G. B. Vollentine

2007 Handbook of Texas Online, s.v. "Gonzales County". Available at: http://www.tsha. utexas.edu/ handbook/online/articles/ GG/ hcg7.html. Accessed June 25, 2007.

Black, S. L.

1989 Central Texas Plateau Prairie. In From the Gulf to the Rio Grande: Human Adaptation in Central, South, and Lower Pecos Texas, by T. R. Hester, S. L. Black, D. G. Steele, B. W. Olive, A. A. Fox, K. J Reinhard, and L. C. Bement, pp. 17-36. Research Series No. 33 Arkansas Archaeological Survey, Fayetteville.

1992 Proposal for the Archeological Evaluation of Historic Properties Along the Wurzbach Parkway, Bexar County, Texas. Proposal submitted to the Texas Department of Transportation. On file. Texas Archeological Research Laboratory, The University of Texas at Austin.

Black, S. L., and D. G. Creel

1997 The Central Texas Burned Rock Midden Reconsidered. In Hot Rock Cooking on the Greater Edwards Plateau: Four Burned Rock Midden Sites in West Central Texas, Volume I, by S. L. Black, L. W. Ellis, D. G. Creel, and G. T. Goode, pp. 269-301. Studies in Archeology 22. Texas Archeological Research Laboratory, The University of Texas at Austin. Archeology Studies Program, Report 2. Texas Department of Transportation, Environmental Affairs Division, Austin, Texas.
Black, S. L., and A. J. McGraw

1985 The Panther Springs Creek Site: Cultural Change and Continuity within the Upper Salado Creek Watershed, South-Central Texas. Archaeological Survey Report 100. Center for Archaeological Research, The University of Texas at San Antonio.

Black, S. L., J. W. Karbula, C. D. Frederick, and C. G. Mear

1998a Archeology along the Wurzbach Parkway, Module 5: Testing and Geoarcheological Evaluation at the Number-6 Site (41BX996) and Other Sites. Studies in Archeology 29. Texas Archeological Research Laboratory, The University of Texas at Austin.

Black, S. L., K. Jolly, C. D. Frederick, J. R. Lucas, J. W. Karbula, P. R. Takac, and D. R. Potter

1998b Archeology along the Wurzbach Parkway, Module 3: Investigation and Experimentation at the Higgiins Site (41BX184). Studies in Archeology 27. Texas Archeological Research Laboratory, The University of Texas at Austin.

Blair, W. F.

1950 The Biotic Provinces of Texas. The Texas Journal of Science 2(1):93-117.

Bolton, H. E.

1970 Texas in the Middle Eighteenth Century: Studies in Spanish Colonial History and Administration. The Texas State Historical Association and the University of Texas Press, Austin.

Bousman, C. B.

1998 Paleoenvironmental Change in Central Texas: The Palynological Evidence. Plains Anthropologist 43:40-59. 
Campbell, R. B.

2003 Gone to Texas: A History of the Lone Star State. Oxford University Press, New York.

Campbell, T. N.

1976 Archeological Investigations at the Morhiss Site, Victoria County, Texas, 1932-1940. In Fox, A., and T. R. Hester, An Archeological Survey of Coleto Creek, Victoria and Goliad Counties, Texas. Archeological Survey Report No. 18, Center for Archeological Research, The University of Texas at San Antonio. Pp. 81-85.

1988 Indians of Southern Texas and Northeastern Mexico: Selected Writings of Thomas Nolan Campbell. Texas Archeological Research Laboratory, with the cooperation of the Department of Anthropology, the College of Liberal Arts, and the Institute of Latin American Studies, The University of Texas at Austin.

Carpenter, S., and K. D. French

2003 Archaeological Survey of the 23-Acre Wurzbach Parkway Overflow Channel, San Antonio, Bexar County, Texas. SWCA Cultural Resources Report No. 02-314.

Castañeda, C. E.

1936-1956 Our Catholic Heritage in Texas, 1519-1936. 7 vols. Von Boeckmann-Jones Co., Austin.

Cecil, P. F., and D. P. Greene

2004 Hays County. The Handbook of Texas Online. Available at: http:tsha. utexas.edu/ handbook/online/articles/ view/HH/hccl. html. Accessed Fri May 14 2:11:23 US/ Central 2004.

Chipman, D. E.

1992 Spanish Texas, 1519-1821. University of Texas Press, Austin, Texas.
Collins, M. B.

1968 A Note on Broad Corner-Notched Projectile Points Used in Bison Hunting in Western Texas. The Bull Roarer 3(2):13-14. The University of Texas Anthropological Society, Department of Anthropology, The University of Texas at Austin.

1990 The Archaeological Sequence at Kincaid Rockshelter, Uvalde County, Texas. Transactions of the Twenty-Fifth Regional Archeological Symposium for Southeastern New Mexico and Western Texas, pp. 25-34.

1998 Early Paleoindian Components. In WilsonLeonard: An 11,000-Year Archeological Record of Hunter-Gatherers in Central Texas, Volume I, edited and assembled by Michael B. Collins, pp. 123-159. Studies in Archeology 31. Texas Archeological Research Laboratory, The University of Texas at Austin. Archeology Studies Program, Report 10. Environmental Affairs Division, Texas Department of Transportation.

2004 Archeology in Central Texas. In The Prehistory of Texas, edited by T. K. Perttula, pp. 101-126. Texas A\&M University Press, College Station.

Collins, M. B., G. L. Evans, T. N. Campbell, M. C. Winans, and C. E. Mear

1989 Clovis Occupation at Kincaid Rockshelter, Texas. Current Research in the Pleistocene $6: 3-4$

Collins, M. B., B. Ellis, and C. Dodt-Ellis

1990 Excavations at the Camp Pearl Wheat Site (41KR243): An Early Archaic Campsite on Town Creek, Kerr County, Texas. Studies in Archeology 6. Texas Archeological Research Laboratory, The University of Texas at Austin.

Collins, M. B., T. R. Hester, and P. J. Hedrick

1992 Engraved Cobbles from the Gault Site, Central Texas. Current Research in the Pleistocene 9:3-4. 
Collins, M.B., C. B. Bousman, and T. K. Perttula

1993 Historic Context: Quaternary Environments and Archeology in Northeastern Texas. In Archeology in the Eastern Planning Region, Texas: A Planning Document, edited by N. A. Kenmotsu and T. K. Perttula, pp. 49-67. Cultural Resource Management Report 3. Department of Antiquities Protection, Texas Historical Commission, Austin.

Collins, M. B., J. Guy, and S. W. Dial

1998 The Archaic Period, 8800 to 1300 B.P. In Wilson-Leonard: An 11,000-Year Archeological Record of Hunter-Gatherers in Central Texas, Volume I, edited and assembled by Michael B. Collins, pp. 211-270. Studies in Archeology 31. Texas Archeological Research Laboratory, The University of Texas at Austin. Archeology Studies Program, Report 10. Environmental Affairs Division, Texas Department of Transportation.

Collins, M. B., D. B. Hudler, and S. L. Black

2003 Pavo Real (41BX52): A Paleoindian and Archaic Camp and Workshop on the Balcones Escarpment, South-Central Texas, Studies in Archeology 41. Texas Archeological Research Laboratory, The University of Texas at Austin. Archeology Studies Program, Report 50. Environmental Affairs Division, Texas Department of Transportation.

Davis, W. B., and D. J. Schmidly

1994 The Mammals of Texas. Texas Parks and Wildlife Department, Austin.

Dering, $\mathrm{P}$.

1999 Earth-Oven Plant Processing in Archaic Period Economies: An Example from a Semi-arid Savannah in South-Central North America. American Antiquity 64(4):659674.

Dibble, D. S., and D. Lorrain

1968 Bonfire Shelter: A Stratified Bison Kill Site, Val Verde County, Texas. Miscellaneous Papers No. 1. Texas Memorial Museum, The University of Texas at Austin.
Fisher, W. L.

1983 Geologic Atlas of Texas, San Antonio Sheet. Bureau of Economic Geology, The University of Texas at Austin.

Foster, W. C.

1995 Spanish Expeditions into Texas, 1689-1768. University of Texas Press, Austin.

Fox, A. A.

1979 Archaeological and Historical Investigations at 41BX180, Walker Ranch, San Antonio, Texas, Phase I. Archaeological Survey Report 83. Center for Archaeological Research, The University of Texas at San Antonio.

1989 Historic Anglo-European Exploration and Colonization, in From the Gulf to the Rio Grande: Human Adaptation in Central, South, and Lower Pecos Texas, by T. R. Hester, S. L. Black, D. G. Steele, B. W. Olive, A. A. Fox, K. J. Reinhard, and L. C. Bement, pp. 85-92. Research Series No. 33. Arkansas Archeological Survey, Fayetteville.

Fox, A., M. Renner, and R. Hard

1997 Archaeologyat the Alamodome: Investigations of a San Antonio Neighborhood in Transition, Volume 1-Historical, Architectural, and Oral History Research. Archaeological Survey Report, No. 236. Center for Archaeological Research, the University of Texas at San Antonio, San Antonio.

Fox, D. E.

1979 The Lithic Artifacts of Indians at the Spanish Colonial Missions, San Antonio, Texas. Special Report No. 8. Center for Archaeological Research, The University of Texas at San Antonio.

Fox, D. E., R. J. Mallouf, and W. M. Sorrow

1974 Archaeological Resources of the Proposed Cuero I Reservoir, DeWitt and Gonzales Counties, Texas. Archaeological Survey Report 12. Texas Historical Commission and Texas Water Development Board, Austin, Texas. 
Goode, G. T.

1991 Late Prehistoric Burned Rock Middens in Central Texas. In The Burned Rock Middens of Texas: An Archeological Symposium, edited by Thomas R. Hester, pp. 71-93. Studies in Archeology 13. Texas Archeological Research Laboratory, The University of Texas at Austin.

Gould, F. W.

1975 Texas Plants: A Checklist and Ecological Summary. Texas Agricultural Experimentation Station, College Station.

Hall, G. D.

1981 Allens Creek: A Study in the Cultural Prehistory of the Brazos River Valley, Texas. Research Report No. 61. Texas Archeological Survey, The University of Texas at Austin.

Handbook of Texas Online, s.v. "GTT,"

2007 Available at: www.tsha.utexas.edu/ handbook/online/articles/GG/pfg1. html. Accessed: June 25, 2007.

Henderson, J., and G. T. Goode

1991 Pavo Real: An Early Paleoindian Site in South-Central Texas. Current Research in the Pleistocene 8:26-28.

Hester, T. R.

1974 Archaeological Survey of Areas Proposed for Modification in the Salado Creek Watershed, Bexar County, Texas. Center for Archaeological Research, The University of Texas at San Antonio, Archaeological Survey Report 3.

1989 Historic Native American Populations. In From the Gulf to the Rio Grande: Human Adaptation in Central, South, and Lower Pecos Texas, by T. R. Hester, S. L. Black, D. G. Steele, B. W. Olive, A. A. Fox, K. J. Reinhard, and L. C. Bement, pp. 77-84. Research Series No. 33. Arkansas Archeological Survey, Fayetteville.

1995 The Prehistory of South Texas. Bulletin of the Texas Archeological Society 66:427-459.
Houk, B. A., and J. C. Lohse

1993 Archeological Investigations at the Mingo Site, Bandera County, Texas. Bulletin of the Texas Archeological Society 61:193-247.

Houk, B. A., S. Tomka, B. Bousman, C. K. Chandler, B. Moses, M. Renner, and M. Lyons

1997 The Greenbelt Core: A Polyhedral Blade Core from San Antonio, Texas. Current Research in the Pleistocene 14:104-106.

Hudson, W.R., Jr., W. Lynn, and D. Scurlock

1974 Walker Ranch, An Archeological Reconnaissance and Excavations in Northern Bexar County, Texas. Office of the State Archeologist Reports No. 26. Texas Historical Commission, Austin.

Huebner, J. A.

1991 Late Prehistoric Bison Populations in Central and Southern Texas. Plains Anthropologist 36(137):343-358.

1995 Past cultures and climates at the Jonas Terrace Site, 41ME29 of Medina County, Texas. Office of the State Archeologist Reports No. 40. Texas Historical Commission, Austin.

Johnson, L., Jr., and G. Goode

1994 New Try at Dating and Characterizing Holocene Climates, as well as Archaeological Periods, on the Eastern Edwards Plateau. Bulletin of the Texas Archeological Society 65:1-15.

Johnson, L., Jr., D. A. Suhm, and C. D. Tunnell

1962 Salvage Archeology of Canyon Reservoir: The Wunderlich, Footbridge, and Oblate Sites. Bulletin No. 5. Texas Memorial Museum, The University of Texas at Austin.

Katz, P. R.

1987 Archaeological Mitigation at 41BX300, Salado Creek Watershed, South-Central Texas. Archaeological Survey Report No. 130. Center for Archaeological Research, The University of Texas at San Antonio. 
Kelly, T. C.

1974 Notes on Test Excavations at Site 41BX228 (Panther Springs Site). Appendix II in Archaeological Survey of Areas Proposed for Modification in the Salado Creek Watershed, Bexar County, Texas, by T. R. Hester:27-32. Center for Archaeological Research, The University of Texas at San Antonio, Archaeological Survey Report 3.

Kelley, J. C., and T. N. Campbell

1942 What are the Burnt Mounds of Texas? American Antiquity 7(3):319-322.

Kerr, A. C., and S. W. Dial

1998 Systematic Analysis of Unfluted Lanceolate and Early Bifurcate Staem Projectile Points. In Wilson-Leonard: An 11,000-Year Archeological Record of Hunter-Gatherers in Central Texas, Volume I, edited and assembled by Michael B. Collins, pp. 447-505. Studies in Archeology 31. Texas Archeological Research Laboratory, The University of Texas at Austin. Archeology Studies Program, Report 10. Environmental Affairs Division, Texas Department of Transportation.

Kibler, K. W., and A. M. Scott

2000 Archaic Hunters and Gatherers of the Balcones Canyonlands: Data Recovery Excavations at the Cibolo Crossing Site (41BX377), Camp Bullis Military Reservation, Bexar County, Texas. Reports of Investigations No. 126. Prewitt and Associates, Inc., Austin.

Kleinbach, K., G. Mehalchick, J. T. Abbott, and J. M. Quigg

1995 Other Analyses. In NRHP Significance Testing of 57 Prehistoric Archeological Sites on Fort Hood, Texas, Volume II, edited by James T. Abbott and W. Nicholas Trierweiler, pp. 765-842. Archeological Resource Management Series, Research Report No. 34. United States Army Fort Hood.
Lich, G. E.

2007 Handbook of Texas Online, s.v. "Smith, Clinton Lafayette and Jefferson Davis," Available at: www.tsha.utexas.edu/ handbook/online/articles/SS/fsm62.html. Accessed: June 25, 2007.

Lukowski, P. D.

1988 Archaeological Investigations at 41BX1, Bexar County, Texas. Archaeological Survey Report No. 135. Center for Archaeological Research, The University of Texas at San Antonio.

McCallum, F. T., and J. M. Owens

2007 Handbook of Texas Online, s.v. "Barbed wire," Available at: www.tsha.utexas.edu/ handbook/online/articles/BB/aob1.html. Accessed: June 25, 2007.

McGraw, A. J.

1979 A Preliminary Archaeological Survey for the Conquista Project in Gonzales, Atascosa, and Live Oak Counties, Texas. Archaeological Survey Report 76. Center for Archaeological Research, The University of Texas at San Antonio.

McGraw, A. J., and K. Hindes

1987 Chipped Stone and Adobe: A Cultural Resources Assessment of the Proposed Applewhite Reservoir, Bexar County, Texas. Archeological Survey Report No. 163. Center for Archeological Research, The University of Texas at San Antonio.

McGraw, A. J., J. W. Clark Jr., and E. A. Robbins, eds. 1998 A Texas Legacy, the Old San Antonio Road and the Caminos Reales: A Tricentennial History, 1691-1991. Second Edition. Texas Department of Transportation Environmental Affairs Division, Austin, Texas.

McKinney, W. W.

1981 Early Holocene Adaptations in Central and Southwestern Texas: The Problem of the Paleoindian-Archaic Transition. Bulletin of the Texas Archeology Society 52:91-120. 
Meltzer, D. J., and M. R. Bever

1995 Paleoindians of Texas: An Update on the Texas Clovis Fluted Point Survey. Bulletin of the Texas Archeological Society 66:47-81.

Miller, K. A., B. A. Houk, C. Howell, L. Nordt, J. Sanchez, M. Waters, and B. Young

1996 Archaeological Survey of the Proposed 130Mile MIDTEXAS Pipeline, Gonzales, DeWitt, Lavaca, Colorado, Austin, and Waller Counties, Texas. SWCA Archaeological Report No. 95-154. SWCA Environmental Consultants, Inc., Austin.

Miller, M., and M. Faux (editors)

1997 The New York Public Library American History Desk Reference. The Stonesong Press, Inc. and the New York Public Library, N.Y.

Petrides, G. A.

1988 Peterson Field Guides: A Guide to Eastern Trees. Houghton Mifflin Company, Boston and New York.

Potter, D. R.

1980 An Archaeological Assessment of 41 BX197 and Vicinity, Walker Ranch National Historic District, San Antonio, Texas. Archaeological Survey Report 91. Center for Archaeological Research, The University of Texas at San Antonio.

Potter, D. R., and S. L. Black

1995 Archeology along the Wurzbach Parkway, Module 2: Initial Testing and Evaluation of Five Prehistoric Sites in the Upper Salado Watershed, Bexar County, Texas. Studies in Archeology 18. Texas Archeological Research Laboratory, The University of Texas at Austin.

Prewitt, E. R.

1981 Cultural Chronology in Central Texas. Bulletin of the Texas Archeological Society 52:65-89.

1985 From Circleville to Toyah: Comments on Central Texas Chronology. Bulletin of the Texas Archeological Society 54:201-238.
Richardson, R. N., E. Wallace, and A. N. Anderson

1981 Texas, The Lone Star State. Fourth Edition. Prentice-Hall, Inc. Englewood Cliffs, N.J.

Ricklis, R., A., M. D. Blum, and M. B. Collins

1991 Archaeological Testing at the Vera Daniels Site (41TV1364), Zilker Park, Austin, Texas. Studies in Archeology 12. Texas Archeological Research Laboratory. The University of Texas at Austin.

Scurlock, D., and W. R. Hudson, Jr.

1973 An Archeological Investigation of Walker Ranch. Office of the State Archeologist Reports No. 9. Texas Historical Commission, Austin.

Simpson, B. J.

1988 A Field Guide to Texas Trees. Texas Monthly Field Guide Series. Texas Monthly Press, Austin, Texas.

Smyrl, V. E.

2007 Handbook of Texas Online, s.v. "San Marcos River". Available at: http://www.tsha.utexas. edu/handbook/online/articles/SS/rns10.html. Accessed: June 25, 2007.

Sorrow, W. M.

1969 Archeological Investigations at the John Ischy Site: A Burned Rock Midden in Williamson County, Texas. Papers of the Texas Archeological Salvage Project No. 18. The University of Texas at Austin.

Steele, D.G., and B. W. Olive

1989 Bioarcheology of Region 3 Study Area. In From the Gulf to the Rio Grande: Human Adaptation in Central, South, and Lower Pecos Texas, by Thomas R. Hester, Stephen L. Black, D. Gentry Steele, Ben W. Olive, Anne A. Fox, Karl J. Reinhard, and Leland C. Bement, pp. 5-16. Research Series No. 33. Arkansas Archeological Survey, Fayetteville. 
Story, D. A.

1985 Adaptive Strategies of Archaic Cultures of the West Gulf Coastal Plain. In Prehistoric Food Production in North America, edited by R. I. Ford, pp. 19-56. Anthropological Papers 75. Museum of Anthropology, University of Michigan, Ann Arbor.

1990 Cultural History of the Native Americans. In The Archeology and Bioarcheology of the Gulf Coastal Plain, by Dee Ann Story, Janice A. Guy, Barbara A. Burnett, Martha Doty Freeman, Jerome C. Rose, D. Gentry Steele, Ben W. Olive, and Karl J. Reinhard, pp. 163-366. Research Series No. 38. Arkansas Archeological Survey, Fayetteville.

Takac, P. R.

1991 Underwater Excavations at Spring Lake: A Paleoindian Site in Hays County, Texas. Current Research in the Pleistocene 8:4648.

Taylor, R. (editor)

1996 The New Handbook of Texas in Six Volumes. The Texas State Historical Association, Austin.

Taylor, A. J., and C. L. Highley

1995 Archeological Investigations at the Loma Sandia Site (41LK28). A Prehistoric Cemetery and Campsite in Live Oak County, Texas, Vol. 1 and 2. Studies in Archeology 20. Texas Archeological Research Laboratory, The University of Texas at Austin.

Taylor, F. B., R. B. Bailey, and D. L. Richardson 1991 Soil Survey of Bexar County, Texas. United States Department of Agriculture, Washington, D.C.

Thoms, A. V., and R. D. Mandel

1992 The Richard Beene Site: A Deeply Stratified Paleoindian to Late Prehistoric Occupation in South-Central Texas. Current Research in the Pleistocene 9:42-44.
Thoms, A. V., D. D. Kuehn, B. W. Olive, J. E. Dockall, P. A. Clabaugh, and R. Mandel

1996 Early and Middle Holocene Occupations at the Richard Beene Site: The 1995 Southern Texas Archaeological Association Field School Project. La Tierra 23(4):8-36.

Thonhoff, R.

2005 Handbook of Texas Online, s.v. "Medina, Battle of". Available at: http://www.tsha. utexas.edu/handbook/online/articles/MM/ qfm1.html. Accessed: June 6, 2005).

Toomey, R. S., III, M. D. Blum, and S. Valastro, Jr.

1993 Late Quaternary Climates and Environments of the Edwards Plateau, Texas. Global and Planetary Change 7:299-320.

Turner, E. S., and T. R. Hester

1999 A Field Guide to Stone Artifacts of Texas Indians. Third Edition. Texas Monthly Field Guide Series. Gulf Publishing Company, Houston, Texas.

Wandsnider, L.

1997 The Roasted and the Boiled: Food Composition and Heat Treatment with Special Emphasis on Pit-Hearth Cooking. Journal of Anthropological Archaeology 16:1-48.

Weir, F. A.

1976 The Central Texas Archaic. Ph.D. dissertation, Department of Anthropology, Washington State University, Pullman.

Wesolowsky, A. B., T. R. Hester, and D. R. Brown

1976 Archeological Investigations at the Jetta Court Site (41TV151) Travis County, Texas. Bulletin of the Texas Archeological Society 47:25-87.

Willey, G. R., and P. Phillips

1958 Method and Theory in American Archaeology. University of Chicago Press, Chicago.

Wilson, E. W.

1930 Burnt Rock Mounds of Southwest Texas. Bulletin of the Texas Archaeological and Paleontological Society 2:59-63. 

APPENDIX A: INTERIM REPORT 



\section{ARCHEOLOGICAL IMPACT EVALUATION}

Notice: Information on the location of archeological sites may not be disclosed to the general public and is protected by State and Federal law.

Date: 2.22.2010

Highway: Wurzbach Parkway: Easement Additions

Counties: Bexar

USGS Quad(s):Castle Hills

CSJ: 0915-12-137, 0915-12-224, 8000-15-015, 8000-

$12-012$

Report Written by: A. McGraw
Date(s) of Survey:

10.02-03.2009

Jurisdiction: Federal $\times \square$ State $\times \square$

District: San Antonio

Performed Under: THC/TXDOT MOU (2004), First

Amended PA (2005)

Project Type: Design change for the addition of permanent and temporary easements

Total Project Impact Acreage: ca. $51.77 \quad$ New ROW Acreage: 0.0 acres

acres

Area of Pedestrian Survey: 51.77 acres

Easement Acreage: ca. 51.77 acres

Project Description and Impacts:

The proposed project is located in an urban and densely populated suburban setting of northern San Antonio, Bexar County. Section 106 consultation for the Wurzbach Parkway undertaking was previously initiated with the SHPO, federally recognized tribes, and other consulting parties. SHPO consultation and concurrence occurred on 11.20.09 and federally recognized tribal consultation was initiated on 9.24.09. This consultation included detailed descriptions of findings, background information, and project description.

At that time as part of the project description, TXDOT noted that a recent minor design change included the addition of construction easements to the proposed undertaking. TxDOT noted that previous archeological studies in similar disturbed local locations have demonstrated little or no potential for intact or significant archeological deposits. As a result, TXDOT proposed that these areas had little or no potential to contain archeological properties that warrant designation as a State Archeological Landmark (13 TAC 26.8) or that were eligible for listing on the National Register of Historic Places.

There is no change in TxDOT's identification or previous recommendation of no affect regarding the proposed easement locations following a recent field inspection to verify the absence of significant archeological sites. The purpose of this report is to provide additional descriptive information on their size, location, and setting to address TXDOT's technical cultural resources reporting standards and those of the First Amended PA (2005) and the TXDOT/THC MOU (2004).

A brief project description is provided as background information and following, Table 1 identifies the location, limits, and acreage of individual easements. Locations are given by permanent control station numbers (CSN) along the road. Additional easement information is provided in Tables 2 and 3. See also attached maps and photos.

\section{Project background.}

The FHWA endorsed an EA as a FONSI in 1992 that included the limits specified for the three unbuilt sections that are the focus of the current project and associated easements. The limits of the Wurzbach Parkway corridor previously addressed in the approved EA were from Lockhill-Selma Road to $\mathrm{IH} 35$, including the Thousand Oaks extension. The previous proposed action is a 4- to 6-lane divided facility with a raised median on new location. Since the EA was approved, work has progressed on acquiring right of way (ROW), developing plans, specifications, and estimates for Sections 3, 4, and 5. Current work is generally consistent with the 1992 schematic of the corridor project. Through this design process, some changes and/or design details have been identified. Wurzbach Parkway would be constructed on new location to accommodate four to six 12-foot (ft) main lanes (three lanes in each direction), an 8-foot median containing a concrete traffic barrier, and 5-ft bike lanes on each side. The proposed typical ROW width is $120 \mathrm{ft}$ wide. Minor changes to the design on Sections 3,4 , and 5 are summarized below: 
From 0.19 mile west of Blanco Road (FM 2696) to West Avenue (Section 3)

Blanco Road to West Avenue (Section 3) is approximately 1.6 miles in length and the overall design configuration has not changed from the 1992 design.

\section{From West Avenue to Jones-Maltsberger Road (Section 4)}

West Avenue to Jones-Maltsberger Road (Section 4) is approximately 1.8 miles in length. In 2005, the proposed project between West Avenue and Jones-Maltsberger was proposed to be modified from the 1992 schematic in order to provide direct connectors between Wurzbach Parkway and US 281. The interchange at US 281 and Wurzbach Parkway was proposed as a single point urban interchange (SPUI), elevated over both US 281 and the mainlanes of Wurzbach Parkway. The design consisted of four elevated direct connectors intersecting at a common point. The direct connector option was dropped from consideration for the proposed project due to funding. In addition, a previous ramp from proposed Wurzbach Parkway to West Coker Loop Road is no longer needed nor proposed. Currently, the 1992 schematic which provided for an overpass of US 281 and at-grade connections to the existing US 281 frontage road is the proposed facility configuration.

Operational improvements on US 281 as part of the proposed project include reversing the existing entrance and exit ramps between Nakoma Drive and Bitters Road on Southbound frontage roads of US 281 and adding a new elevated turnaround at Nakoma Drive for south-bound traffic. For the northbound traffic of US 281, the proposed project would move the existing 2-lane ramp near Arion Parkway to the south in order to access proposed Wurzbach Parkway and add a new grade-separated exit to Bitters Road from US 281 as well as a new entrance to Bitters Road from Wurzbach Parkway. In addition, the US 281 overpass at Bitters Road would be widened from 3 lanes each direction to 4 lanes each direction. Operational improvements to US 281 as a result of the proposed project would be accomplished within the existing US 281 ROW.

\section{From Jones-Maltsberger Road to 0.43 mile west of Wetmore Road (Section 5)}

Jones-Maltsberger Road to Wetmore Road (Section 5) is approximately 1.4 miles in length, This proposed section of the roadway includes the replacement of a bridge structure at the Salado Creek oxbow west with a pipe culvert to maintain low flow. Proposed access would be provided from Wurzbach Parkway to COSA's brush recycling center.

\section{Proposed Easement Locations}

\section{Area of Potential Effects (APE):}

Permanent easements totaling ca. 2.94 acres will be required for the proposed project. Additional temporary construction easements will be required for the proposed project for a total area of approximately 48.83 acres. These are grouped in Table 1 by RT and LT (right and left of highway centerline) and by adjacent, contiguous, and overlapping control station numbers. The distance from centerline to ROW of an individual section is given in feet and its area is listed in acres. Easement locations are located adjacent to ROW and their width and lengths and listed in Table 2. The location of construction easements $A$ and $B$ that require modifications to an existing driveway entrance and intersection were previously included in the description of project activities but were subsequently redesignated as temporary construction easements. Individual easement locations vary widely in size (ca. 05 to 28.9 acres) and are shaped as irregular polygons immediately adjacent to the ROW.

Table 1. Proposed easement locations. PE = permanent,$T E=$ temporary easement location

\begin{tabular}{|c|c|c|c|c|}
\hline Locale & Station Begin & Station End & Acreage & Type \\
\hline 1 & $96+93.64,116.48^{\prime}$ LT & $98+09.03,109.99^{\prime}$ LT & 0.053 & PE \\
\hline 2 & $228+44.63,60.00^{\prime}$ RT & $238+38.18,76.16^{\prime}$ RT & 0.929 & PE \\
\hline 3 & $247+07.79,117.69^{\prime}$ RT & $250+69.83,198.44^{\prime}$ RT & 0.403 & PE \\
\hline 4 & $285+73.25,69.97^{\prime}$ RT & $313+93.96,178.76^{\prime}$ RT & 28.965 & TE \\
\hline
\end{tabular}




\begin{tabular}{|c|c|c|c|c|}
\hline & $286+10.14,70.03^{\prime}$ 'T & $313+44.02,208.86^{\prime}$ LT & 2.275 & \\
\hline 5 & $314+61.44,178.76^{\prime}$ 'RT & $318+58.21,114.51^{\prime}$ RT & 1.412 & PE \\
& $316+49.78,170.39 '$ 'T & $326+15.15,135.49^{\prime}$ LT & 0.292 & TE \\
& $318+59.10,154.43^{\prime}$ RT & $327+72.31,111.25^{\prime}$ RT & 1.756 & TE \\
& $328+36.40,110.11^{\prime}$ RT & $346+01.09,59.84^{\prime}$ RT & 0.921 & TE \\
& $327+80.59,71.06^{\prime}$ RT & $328+43.56,70.05^{\prime}$ RT & 0.138 & PE \\
& & & & intersection, TE \\
\hline A & $279+05.34,60.02^{\prime}$ LT & $282+79.39,60.03^{\prime}$ LT & 0.744 & existing driveway, TE \\
\hline B & $261+31.22,93.39^{\prime}$ RT & $284+73.15,69.97^{\prime}$ RT & 13.404 & \\
& $261+30.95,89.99^{\prime}$ LT & $270+63.21,60.00^{\prime}$ LT & 0.471 & \\
\hline
\end{tabular}

\section{Typical Impacts}

The majority of the easements are linear, parallel to the highway, and often $40-50$ feet wide. Average depth of construction at easements are within 3 feet of existing ground surface but maximum depth of construction impact at easement locale 4 is estimated at 20 feet to accommodate a storm water outfall. See attached maps for easement locations.

Table 2. Estimated length and width of proposed easements.

\begin{tabular}{|c|c|c|c|c|c|}
\hline Locale & Station Begin & Station End & $\begin{array}{l}\text { Acreage } \\
\text { (ca.) }\end{array}$ & Length (ca.) & Width (ca.) \\
\hline 1 & $96+93.64,116.48^{\prime}$ LT & $98+09.03$ & 0.053 & $100.16^{\prime}$ & $50^{\prime}$ \\
\hline 2 & $228+44.63,60.00^{\prime}$ RT & $238+38.18$ & 0.929 & $900.40^{\prime}$ & $40^{\prime \prime}$ \\
& & & & & \\
\hline 3 & $247+07.79,117.69^{\prime}$ RT & $250+69.83$ & 0.403 & $362.00^{\prime}$ & $20^{\prime}$ \\
\hline $4^{*}$ & $285+73.25,69.97^{\prime}$ RT & $313+93.96$ & 28.965 & $2,820.00^{\prime}$ & varies $^{\star}$ \\
& $286+10.14,70.03^{\prime}$ LT & $313+44.02$ & 2.275 & $2,734.00^{\prime}$ & $50^{\prime}$ \\
\hline 5 & $314+61.44,178.76^{\prime}$ RT & $318+58.21$ & 1.412 & $397.00^{\prime}$ & $75^{\prime}$ \\
& $316+49.78,170.39^{\prime}$ LT & $326+15.15$ & 0.292 & $966.00^{\prime}$ & $25-40^{\prime}$ \\
& $318+59.10,154.43^{\prime}$ RT & $327+72.31$ & 1.756 & $913.00^{\prime}$ & $45^{\prime}$ \\
& $328+36.40,110.11^{\prime}$ RT & $346+01.09$ & 0.921 & $1,765.00^{\prime}$ & $40^{\prime}$ \\
& $327+80.59,71.06^{\prime}$ RT & $328+43.56$ & 0.138 & $63.00^{\prime}$ & $40^{\prime}$ \\
& & & & & $30^{\prime}$ \\
\hline A & $279+05.34,60.02^{\prime}$ LT & $282+79.39$ & 0.744 & $374.00^{\prime}$ & $75^{\prime}$ \\
\hline B & $261+31.22,93.39^{\prime}$ RT & $284+73.15$ & 13.404 & $2,342.00^{\prime}$ & $35^{\prime}$ \\
& $261+30.95,89.99^{\prime}$ LT & $270+63.21$ & 0.471 & $933.00^{\prime}$ & \\
\hline
\end{tabular}

* variable; storm water overflow/outfall corridor; total area is ca. 28.965 acres. This easement corridor was previously surveyed in 2003 under THC Antiquities Permit No. 2945; no archeological sites were recorded. 
Parcel \#: multiple. Land ownerships that include city, commercial, and private, are listed on attached maps. Project Area Ownership: see above.

\section{Project Setting}

Topography: Situated along the margin of the Balcones Escarpment and Fault Zone in northern Bexar County. Characterized by low rolling hills of exposed limestone over thin eroded calcareous soils.

Geology: Cretaceous marine limestone of Austin Chalk overlain by Quaternary fluvial deposits. The chalk is underlain by the Eagle Ford Group of shaley limestone and calcareous shale.

Soils: six soil types are mapped within the APE: Trinity and Frio, Lewisville silty clay, Patrick soils, Tarrant soils, Pits and quarries, and Austin silty clay. Three mappable alluvial deposits have been identified along the drainages ranging in age from Late Pleistocene to modern. Further information is presented in the previously coordinated report of archeological investigations, Galindo et. al, 2007 under THC Antiquities Permit No. 4494.

Land Use: Extensively altered by modern commercial and residential development within a highly urbanized city setting.

Vegetation: short grasses along ROW and within adjacent easement areas or previously cleared by private, city, or commercial developments.

\section{Estimated Ground Surface Visibility: 85\%}

Previous Investigations and Known Archeological Sites: Multiple: see the previously coordinated report of archeological investigations for the Wurzbach Parkway project, Galindo et. al, 2007, under THC Antiquities Permit No. 4494.

Comments on Project Setting: Over-all area of proposed easement locations is highly disturbed and severely impacted by extensive and long-term residential, commercial, private, and city developments that have occurred adjacent to the project's ROW. See attached photographs. These impacts have severely compromised or destroyed the integrity and intactness of any potential archeological site. As a result, the easement locales contain little or no potential to contain significant or intact archeological historic properties.

Methods: Impact evaluation by pedestrian inspection and surface survey. Disturbed condition and lack of integrity in easement settings precluded shovel probes.

Performed by: A. McGraw

\section{Results of Assessment}

Table 3.

\begin{tabular}{|c|l|l|}
\hline Locale & Station Begin & Description of Project Area and Previous Impacts \\
\hline 1 & $96+93.64,116.48^{\prime}$ LT & $\begin{array}{l}\text { located west of West Avenue along creekbed and T-0 and T-1 } \\
\text { terrace of Panther Springs Creek. Area previously disturbed by } \\
\text { land clearing and construction of SCS floodwater retarding } \\
\text { structure (dam). }\end{array}$ \\
\hline 2 & $228+44.63,60.00^{\prime}$ RT & $\begin{array}{l}\text { easement area includes front asphalt parking lot of San Antonio } \\
\text { RPFIV Business Park Association building and business park } \\
\text { complex. }\end{array}$ \\
\hline 3 & $247+07.79,117.69^{\prime}$ RT & $\begin{array}{l}\text { easement is ca. 20' wide along western approach to J. } \\
\text { Maltsberger intersection. Locale is in frequently flooded T-0 and }\end{array}$ \\
\hline
\end{tabular}




\begin{tabular}{|c|c|c|}
\hline & & $\begin{array}{l}\text { T-1 floodplain with numerous exposures of gravel bars along } \\
\text { adjacent creekbed. }\end{array}$ \\
\hline 4 & $\begin{array}{l}285+73.25,69.97 ' \text { RT } \\
286+10.14,70.03 ' \text { LT }\end{array}$ & $\begin{array}{l}\text { previous illegal dump site in high-energy frequently flooded T-0 } \\
\text { flood plain of Salado Creek along south ROW.. } \\
\text { Same as above along north ROW. See note in Table } 2 .\end{array}$ \\
\hline 5 & $\begin{array}{l}\text { 314+61.44, 178.76'RT } \\
\text { 316+49.78, 170.39' LT } \\
\text { 318+59.10, 154.43' RT } \\
\text { 328+36.40, 110.11' RT } \\
\text { 327+80.59, 71.06' RT }\end{array}$ & $\begin{array}{l}\text { ca. a 75' wide easement in frequently flooded flood plain of } \\
\text { Salado Creek, numerous exposures of relic gravel bars and } \\
\text { stream rolled cobbles on surface. Previously cleared by City of } \\
\text { San Antonio. Adjacent land use is city sanitation/recycling } \\
\text { center. } \\
\text { ca. } 40 \text { ' wide easement along undeveloped City of San Antonio } \\
\text { property previously cleared by bulldozing and tree removals. }\end{array}$ \\
\hline$A$ & 279+05.34, 60.02' LT & $\begin{array}{l}\text { immediately adjacent to existing city street intersection } \\
\text { previously impacted by former land clearing and street } \\
\text { construction }\end{array}$ \\
\hline B & $\begin{array}{l}\text { 261+31.22, 93.39' RT } \\
261+30.95,89.99^{\prime} \text { LT }\end{array}$ & $\begin{array}{l}\text { Along upland margin and parallel to Old Bitters Road. Includes } \\
\text { western approach to/and existing driveway entrance of city } \\
\text { brush dump. Easement location has been previously impacted } \\
\text { by complete surface land clearing and brush removal by the city. } \\
\text { Easement adjacent to north ROW has been previously cleared } \\
\text { and leveled as portion of undeveloped business park and sports } \\
\text { complex adjacent to Old Bitters Road. }\end{array}$ \\
\hline
\end{tabular}

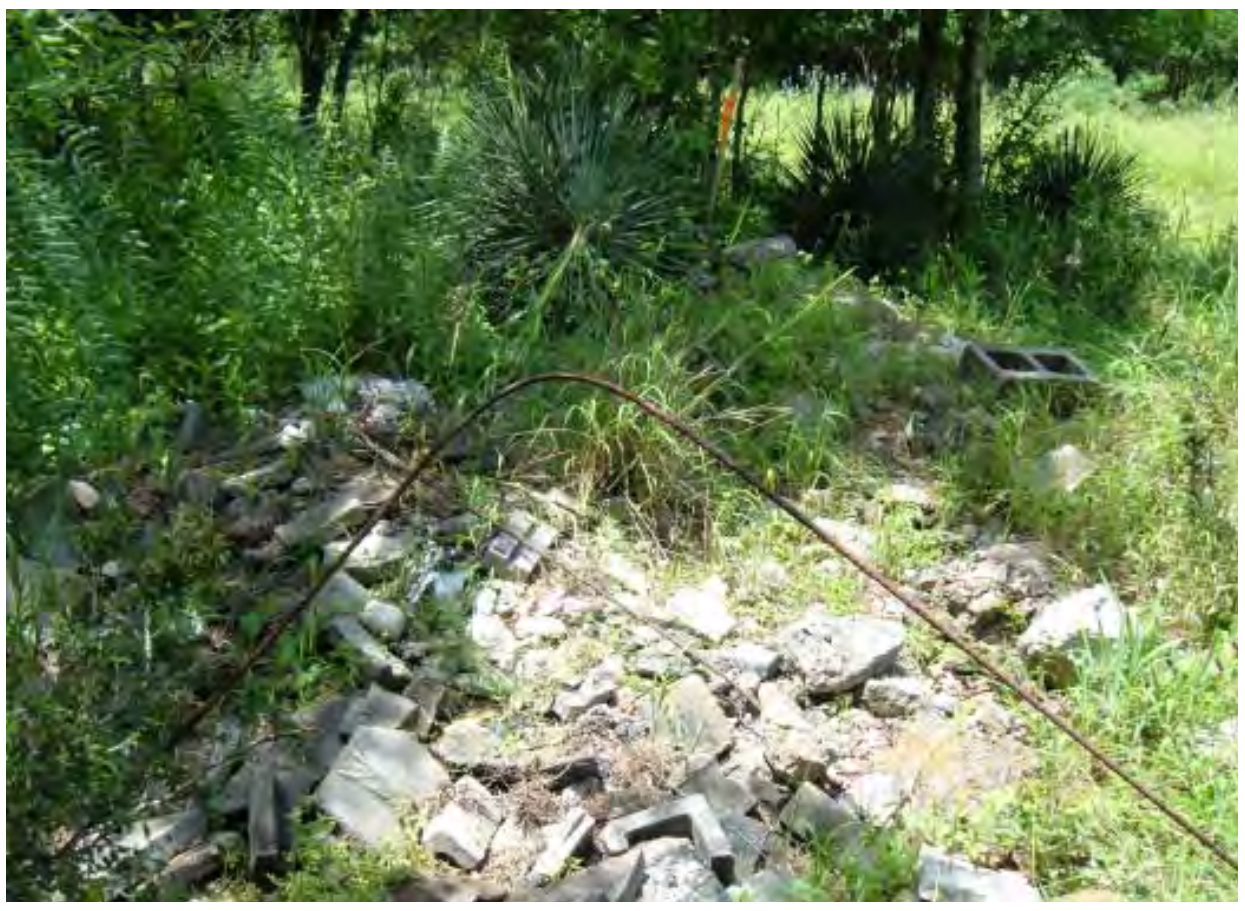

Figure 1. Construction debris and disturbed surfaces west of CSN 228+44. 


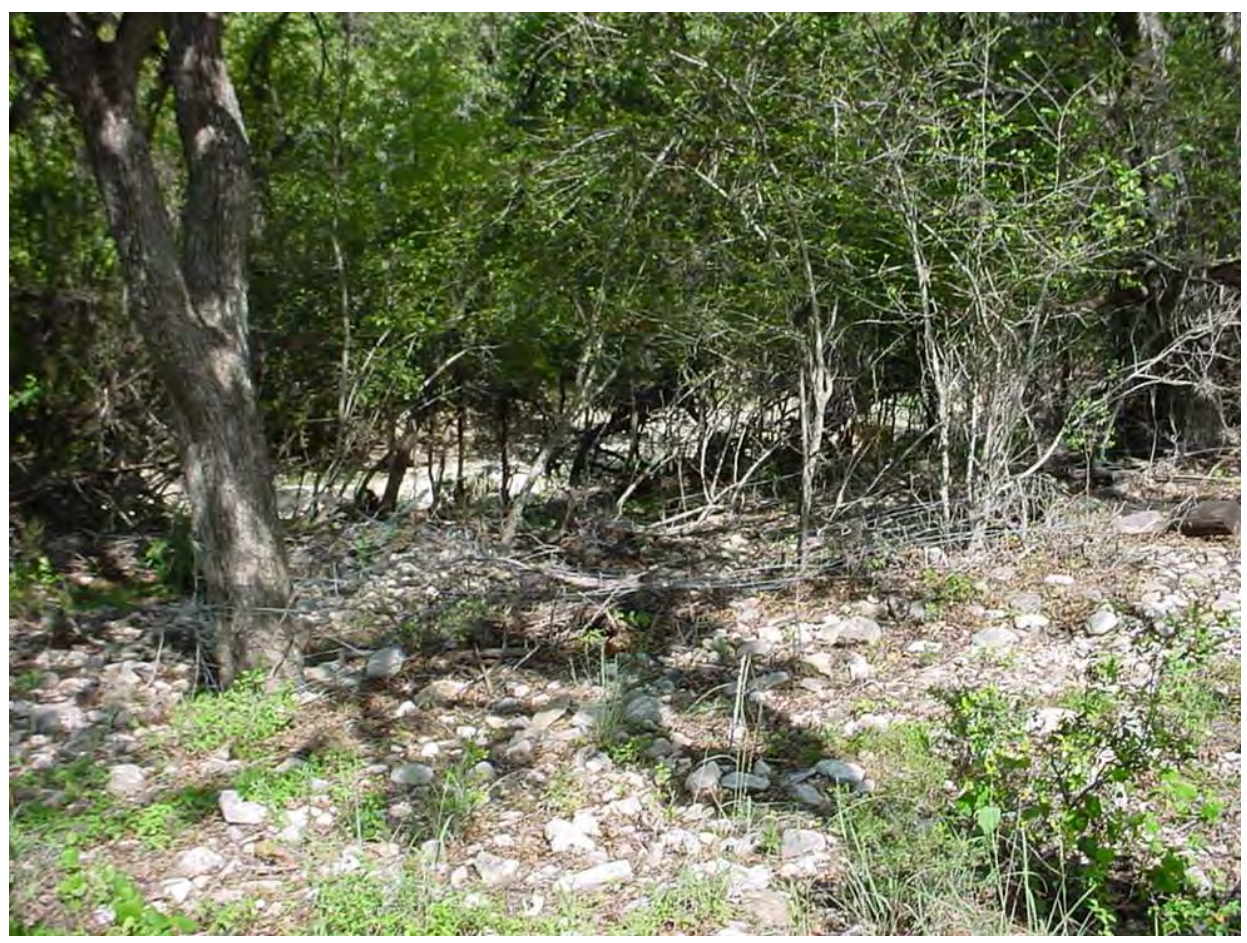

Figure 2. Frequently flooded T-0 terrace along Salado Creek vicinity of CSN 250+00.

\section{Recommendations}

No previously recorded sites nor evidence of archeological materials were observed at the easement locations. Previous impacts in the form of former land clearing, commercial construction, former street construction, as well as natural erosion and the frequent scouring of low-lying terraces within the easement locations negatively affect and compromise the integrity of location, materials, and associations of an archeological deposit, if it existed, within the easement areas. In addition, previous and numerous archeological studies in similar settings of northern Bexar County have historically demonstrated the low or non-existent potential of such locales to contain significant archeological sites. As a result, no further work is recommended.

Pursuant to Stipulation VI of the PA-TU, there is no change in TXDOT's previous recommendation that the proposed easement locations do not contain or will affect archeological historic properties (36 CFR 800.16(I)). In addition, the easement locations do not merit intensive survey or additional field investigations in compliance with the MOU (43 TAC 2.24(f)(1)(C). In the event that unanticipated archeological deposits are encountered during construction, work in the immediate area will cease and TXDOT archeological staff will be contacted to initiate postreview discovery procedures under the provisions of the First Amended PA (2005) and MOU (2004).

Comments and Justification: see above.

\section{References}

Galindo, M. J. and Miller, K.

2007 Intensive Cultural Resources Survey of the Proposed Wurzbach parkway Extension Project From Blanco Road to Wetmore Road, Bexar County, Texas. SWCA, THC Permit No. 4494. 